\title{
APLICABILIDADE DE PRODUTOS DE SSENSORES \\ REMOTOS NA CARACTERIZAÇÃO FISIOGRÁFICA \\ PARA MAPEAMENTOS DE SOLOS
}

\section{RUI MARCONI PFEIFER}

Engenheiro Agrônomo

Orientador: Prof $^{\circ}$ Dr. GERALDO VICTORINO DE FRANÇA

Tese apresentada à Escola Superior de Agricultura "Luiz de Queiróz", da Universidade de São Paulo, para obtenção do título de Doutor em Agronomia, Área de Concentração: Solos e Nutrição de Plantas.

P I R A C I C A B A

Estado de São Paulo - Brasil

Julho - 1995 
Dados internacionais de Catalogação na Publicação (CIP) Divisão de Biblioteca e Documentação - CAMPUS "LUIZ DE QUEIROZ"/USP

Pfeifer, Rui Marconi

Aplicabilidade de produtos de sensores remotos na caracterização fisiográfica. . Piracicaba, 1995.

215p. ilus.

Tese - ESALQ

Bibliografia.

1. Recurso natural - Levantamento - Parque Estadual da I lha do Cardoso 2. Sensoriamento remoto 3. Solo - Levantamento I. Escola Supe rior de Agricultura Luiz de Queiroz, Piracicaba

CDD 631.47 


\section{APLICABILIDADE DE PRODUTOS DE SENSORES REMOTOS NA CARACTERIZAÇÃo FISIOGRÁFICA \\ PARA MAPEAMENTO DE SOLOS}

\section{RUI MARCONI PFEIFER}

Aprovada em: 03.10.1995

Comissão Julgadora:

Prof. Dr. Geraldo Victorino de França

Prof. Dr. Hilton Thadeu Zarate do Couto

Prof. Dr. Valdemar Antonio Demétrio

Prof. Dr. Carlos Roberto Espíndola

Prof $^{\text {a }}$ Dr $^{\text {a }}$ Wolmar Apparecida Carvalho
ESALQ/USP

ESALQ/USP

ESALQ/USP

FEAGRI/UNICAMP

FCA/UNESP

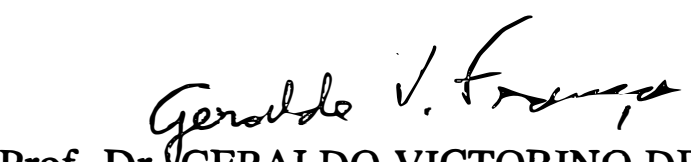

Prof. Dr. GERALDO VICTORINO DE FRANÇA Orientador 
Aos colegas,

AGRADEÇO.

Aos amigos,

companheiros em todas circunstâncias, DEDICO. 


\section{AGRADECIMENTOS}

Ao Prof. Dr. GERALDO VICTORINO DE FRANÇA, pela dedicação, colaboração e valiosa orientação.

A Prof ${ }^{a} \operatorname{Dr}^{\mathrm{a}}$ WOLMAR APPARECIDA CARVALHO, que pelo estímulo nos conduziu à investigação científica em pedologia.

A RIVADAVIA APARECIDO DA SILVA, pelo apoio irrestrito em todos os momentos.

A MARCELO CORRÊA ALVES, pela orientação e colaboração nas análises estatísticas.

Ao Prof. Dr. GERALDO HENRIQUE MOURA FLORSHEIM, pela revisão do Summary.

Ao CONSELHO NACIONAL DE DESENVOLVIMENTO CIENTÍFICO E TECNOLÓGICO - CNPq, pelo auxílio financeiro prestado na execução deste trabalho.

Ao INSTITUTO FLORESTAL e a todos que, direta ou indiretamente contribuiram para o desenvolvimento desta pesquisa. 


\section{SUMÁRIO}

Página

LISTA DE FIGURAS...................................................... v

LISTA DE TABELAS................................................... vii

RESUMO................................................................

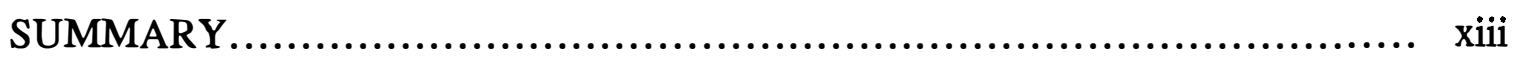

1. INTRODUÇÃO..................................................... 1

2. REVISÃO DE LITERATURA........................................ 4

2.1. Aplicação da Fotografia Aérea: Generalidades........................ 4

2.1.1. Fundamentos da fotointerpretação.............................. 6

2.1.2. Análise morfométrica....................................... 11

2.1.2.1. Padrão de drenagem: tipos, características e significado. 11

2.1.2.2. Bacias hidrográficas como critério de estudo da rede de drenagem....................................... 14

2.1.2.3. Amostras circulares como critério de estudo da rede de drenagem............................................ 21

2.2. Imagens Orbitais Aplicadas ao Estudo de Solos....................... 23

2.2.1. Generalidades................................................. 23

2.2.2. Rede de drenagem superficial................................ 29

2.2.3. Elementos do relevo......................................... 32

2.2.4. Tonalidade e textura fotográfica.............................. 33 
2.3. Imagens de Radar Aplicadas ao Estudo de Solos....................... 35

3. MATERIAL E MÉTODOS............................................... 44

3.1. Material............................................................ 44

3.1.1. Caracterização do meio físico................................. 44

3.1.1.1. Localização............................................ 44

3.1.1.2. Geologia-geomorfologia............................... 44

3.1.1.3. Solos............................................. 59

3.1.1.4. Clima.................................................. 65

3.1.1.5. Vegetação.............................................. 69

3.1.1.6. Correlação entre características do meio biofísico do

P.E. da Ilha de Cardoso................................. 71

3.1.2. Material cartográfico...................................... 76

3.1.3. Produtos de sensores remotos............................... 78

3.1.4. Equipamentos............................................ 79

3.2. Métodos......................................................... 79

3.2.1. Seleção e interpretação da área de estudo........................ 79

3.2.2. Obtenção dos mapas básicos de drenagem....................... 80

3.2.3. Delimitação de áreas homogêneas quanto ao relevo............... 82

3.2.4. Mapeamento das unidades fisiográficas....................... 82

3.2.5. Caracterização das unidades fisiográficas quanto à rede de drenagem e ao relevo........................................ 84

3.2.5.1. Rede de drenagem superficial......................... 84 
3.2.5.2. Relevo............................................. 88

3.2.6. Caracterização pedológica das unidades fisiográficas.............. 90

3.2.7. Reambulação..................................................... 91

3.2.8. Análise estatística.............................................. 92

3.2.8.1. Introdução............................................... 92

3.2.8.2. Passos da análise........................................ 96

4. RESULTADOS E DISCUSSÃO........................................ 104

4.1. Mapas da Rede de Drenagem Superficial............................ 104

4.2. Mapas das Unidades Fisiográficas............................... 110

4.3. Características Dimensionais das Unidades Fisiográficas............... 114

4.4. Características Quantitativas e Qualitativas das Drenagens Superficial

e do Relevo........................................................... 118

4.5. Correlação Pedológica das Unidades Fisiográficas...................... 122

4.6. Análise de Agrupamentos........................................... 129

4.6.1. Fotografias aéreas na escala aproximada de $1: 25.000 \ldots \ldots \ldots \ldots . .129$

4.6.2. Imagem TM/Landsat - composição colorida 3, 4, 5 - na escala

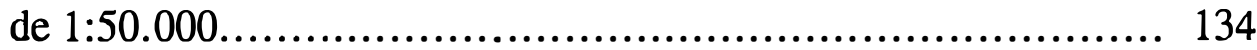

4.6.3. Imagem de radar GEMS 1000, banda X, cópia "off set", na

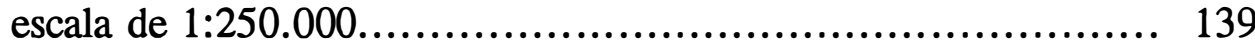

4.7. Avaliação da Eficiência dos Elementos de Interpretação da Rede de

Drenagem Superficial.

4.7.1. Características descritivas do padrão de drenagem............... 154 
4.8. Avaliação da Eficiência dos Elementos de Interpretação de Relevo...... 159

4.9. Considerações sobre os Resultados da Análise de Agrupamentos........ 165

4.10. Considerações sobre as Relações Interpretativas dos Parâmetros da

Drenagem Superficial e do Relevo com os Diversos Produtos de

Sensores Remotos.................................................... 169

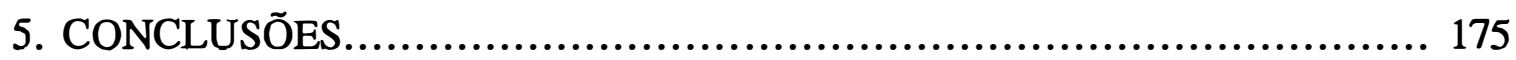

REFERÊNCIAS BIBLIOGRÁFICAS.................................. 178

APÊNDICES........................................................... 203 


\section{LISTA DE FIGURAS}

FIGURA

Página

1. Mapa de localização do Parque Estadual da Ilha do Cardoso, SP........... 45

2. Características geomorfológicas e as formações superficiais do P.E.

da Ilha do Cardoso, SP.............................................. 55

3. Mapa geomorfológico............................................. 57

4. Carta pedológica..................................................... 60

5. Gráfico do balanço hídrico............................................. 68

6. Mapa da vegetação do P.E. da Ilha do Cardoso - as principais formações... $\quad 70$

7. Mapa de localização do perfil topográfico A - B........................ 72

8. Correlações de características do meio biofísico do P.E. da Ilha do

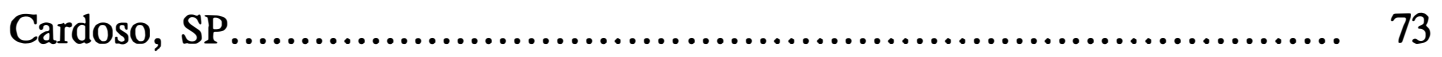

9. Exemplo hipotético de dendrograma................................ 102

10. Mapa da rede de drenagem do P.E. da Ilha do Cardoso, SP (extraído de fotografias aéreas da cobertura aerofotogramétrica do Estado de São Paulo, de 1972, na escala aproximada de 1:25.000)................ 105

11. Mapa da rede de drenagem superficial do P.E. da Ilha do Cardoso, SP (extraído de imagem TM/Landsat, composição colorida 3, 4, 5, de

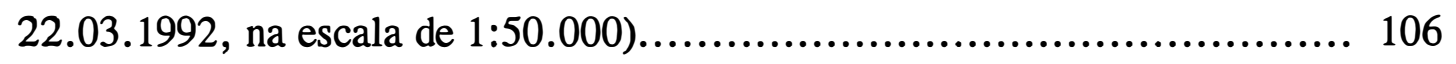


12. Mapa da rede de drenagem superficial do P.E. da Ilha do Cardoso, SP (extraído de imagem de radar GEMS 1000, banda X, cópia "off set" do mosaico semicontrolado de 1976 , na escala de 1:250.000)

13. Mapa de localização das unidades fisiográficas (I a XXVIII), obtidas de fotografias aéreas de 1972, na escala aproximada de 1:25.000).

14. Mapa de localização das unidades fisiográficas (I a XX), obtidas de imagem TM/Landsat, composição colorida 3, 4, 5, na escala de $1: 50.000)$

15. Mapa de localização das unidades fisiográficas (I a VI), obtidas de imagem de radar GEMS 1000, banda X, cópia "off set" do mosaico semicontrolado de 1976, na escala de 1:250.000)

16. Dendrograma da Análise de Agrupamentos dos padrões de drenagem superficial, extraídos das aerofotografias na escala de aproximada $1: 25.000$

17. Dendrograma da Análise de Agrupamentos dos padrões de drenagem superficial, extraídos da imagem TM/Landsat - composição colorida

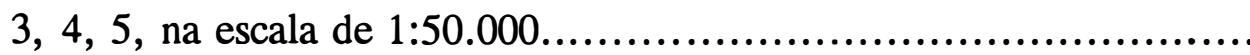

18. Dendrograma da Análise de Agrupamentos dos padrões de drenagem superficial, extraídos da imagem de radar GEMS 1000, banda X, cópia "off set", na escala de 1:250.000 


\section{LISTA DE TABELAS}

TABELA

Página

1. Dados meteorológicos da Estação de Cananéia (SP)........................ 66

2. Balanço hídrico segundo THORNTHWAITE \& MATHER, 1955.......... 67

3. Características dimensionais das unidades fisiográficas extraídas de fotografias aéreas de 1972, na escala aproximada de $1: 25.000 \ldots \ldots \ldots \ldots \ldots . .115$

4. Características dimensionais das unidades fisiográficas extraídas de imagem TM/Landsat, de 22.03.1992, na escala de 1:50.000

5. Características dimensionais das unidades fisiográficas extraídas de de imagem de radar GEMS 1.000, banda X, cópia "off set" do mosaico semicontrolado de 1976, na escala de 1:50.000.

6. Características quantitativas e qualitativas dos padrões de drenagem superficial e do relevo (codificadas), das unidades fisiográficas extraídas das fotografias aéreas de 1972, na escala aproximada de 1:25.000...

7. Características quantitativas e qualitativas dos padrões de drenagem superficial e do relevo (codificadas), das unidades fisiográficas extraídas de imagem TM/Landsat, composição colorida 3, 4, 5, de 22.3.1992, na escala 1:50.000. 120

8. Características quantitativas e qualitativas dos padrões de drenagem superficial e do relevo (codificadas), das unidades fisiográficas extraídas de imagem de radar GEMS 1.000, banda X, cópia "off set" do mosaico semicontrolado de 1976 , na escala 1:250.000 
9. Correlação pedológica das unidades fisiográficas do P.E. da Ilha do Cardoso, SP.

10. Estatística descritiva de variáveis contínuas dos padrões de drenagem superficial obtidas a partir de aerofotografias na escala aproximada de $1: 25.000$

11. Estatística descritiva de variáveis contínuas dos padrões de drenagem superficial obtidas a partir de imagem TM/Landsat - composição colorida $3,4,5$, na escala $1: 50.000$ 138

12. Estatística descritiva de variáveis contínuas dos padrões de drenagem superficial obtidas a partir de imagem de radar GEMS 1.000, banda X, cópia "off set", na escala 1:250.000

13. Resultados do Teste $\mathrm{F}$ para as variáveis quantitativas da rede de drenagem superficial dos grupos (GR) definidos a partir de sensores remoto e respectivas escalas.

14. Resultados do Teste de Tukey, ao nível de $5 \%$ de probabilidade, para a variável Densidade de Drenagem. 148

15. Resultados do Teste de Tukey, ao nível de 5\% de probabilidade, para a variável Freqüência de Rios.

16. Resultados do Teste de Tukey, ao nível de $5 \%$ de probabilidade, para a variável Comprimento Médio de Rios.

17. Resultados do Teste de Tukey, ao nível de 5\% de probabilidade, para a variável Razão de Textura 
18. Resultados do Teste de Kruskal-Wallis, ao nível de 5\% de probabilidade, para os parâmetros qualitativos da rede de drenagem superficial dos grupos definidos a partir dos produtos de sensores remotos e respectivas escalas

19. Resultados do Teste de Kruskal-Wallis, ao nível de 5\% de probabilidade, para os parâmetros do relevo dos grupos (GR) definidos a partir dos produtos de sensores remotos e respectivas escalas.

20. Médias calculadas para densidade de drenagem (Dd), freqüência de rios (Fr), comprimento médio de rios $(\mathrm{Lm})$ e razão de textura $(\mathrm{T})$, bem como para a textura topográfica (Tt) - segundo FRANÇA (1968) - para os tipos de solos, nas escalas estudadas. 


\title{
APLICABILIDADE DE PRODUTOS DE SENSORES REMOTOS
}

\author{
NA CARACTERIZAÇÃO FISIOGRÁFICA \\ PARA MAPEAMENTO DE SOLOS
}

Autor: RUI MARCONI PFEIFER

Orientador: Prof. Dr. GERALDO VICTORINO DE FRANÇA

\section{RESUMO}

Visando avaliar a potencialidade do emprego de produtos de sensores remotos em levantamentos pedológicos, apresenta-se a interpretação visual da rede de drenagem superficial e de relevo do Parque Estadual da Ilha do Cardoso. A Ilha do Cardoso situa-se entre os paralelos $25^{\circ} 05^{\prime}$ e $25^{\circ} 15^{\prime}$ de latitude sul e os meridianos $47^{\circ} 53^{\prime}$ e $48^{\circ} 06^{\prime}$ de longitude W. Gr., no extremo sul do Estado de São Paulo - Brasil, com uma área aproximada de 22.500 ha. Através da interpretação de fotografias aéreas na escala aproximada de 1:25.000; de imagem TM/Landsat - composição colorida 3,4,5 - na escala de 1:50.000; e de imagem de radar GEMS 1.000, banda X, cópia "off set" do mosaico semicontrolado na escala de 1:250.000, foi elaborada a compartimentação do terreno em áreas homogêneas, denominadas de unidades fisiográficas. Cada unidade 
foi caracterizada quanto a elementos qualitativos e quantitativos da drenagem e apenas descritivos do relevo. Na definição de grupos de unidades fisiográficas referentes aos diferentes tipos de solos, foi utilizada a Análise de Agrupamentos, técnica da Análise Multivariada, através dos elementos de interpretação. Também foi verificada a eficiência de cada elemento na discriminação entre os diferentes grupos, através de criteriosa análise estatística paramétrica e não-paramétrica. A análise e discussão dos resultados obtidos possibilitaram as seguintes conclusões:

- no traçado da rede de drenagem superficial e na delimitação de áreas homogêneas, as maiores contribuições foram dadas pela interpretação das fotografias aéreas, seguidas da interpretação da imagem TM/Landsat, em relação à imagem de radar;

- a utilização da Análise de Agrupamentos possibilitou a formação de grupos de unidades fisiográficas relacionadas aos solos morfogeneticamente semelhantes;

- os elementos frequência de rios (entre as características quantitativas), grau de controle e angularidade (entre as características qualitativas) da rede de drenagem superficial e os elementos posição topográfica, tipo e classe de relevo, foram as variáveis mais eficientes no agrupamento de unidades fisiográficas, tanto para a escala aproximada de 1:25.000, quanto para a escala de 1:50.000. 
as características da rede de drenagem superficial e do relevo não apresentaram resultados significativos para a separabilidade dos grupos de unidades fisiográficas na escala de 1:250.000;

os elementos de interpretação, nos diversos produtos de sensores remotos, aplicados ao estudo de solos, não devem ser analisados isoladamente, mas conjuntamente; e,

a metodologia empregada no P.E. da Ilha do Cardoso mostrou-se potencialmente válida para levantamentos de solos, ao nível de semidetalhe, realizados com o auxílio de aerofotografias na escala aproximada de 1:25.000, podendo-se recomendar para um nível de reconhecimento o auxílio de imagem orbital na escala de 1:50.000 e para um nível mais generalizado o auxílio da imagem de radar na escala de 1:250.000. 


\title{
APLICABILITY OF REMOTE SENSING PRODUCTS TO THE PHYSIOGRAPHIC CHARACTERIZATION FOR SOIL MAPPING
}

\author{
Author: RUI MARCONI PFEIFER \\ Adviser: Prof. Dr. GERALDO VICTORINO DE FRANÇA
}

\section{SUMMARY}

This study aims at evaluating the potential utilization of remote sensing products in soil survey. The visual interpretation of the superficial drainage patterns and relief characteristics of the Cardoso Island State Park is presented. The Cardoso Island is located between $25^{\circ} 05^{\prime}$ and $25^{\circ} 15^{\prime}$ latitude South and $47^{\circ} 53^{\prime}$ and $48^{\circ} 06^{\prime}$ longitude West Greenwich, at the southern end of the State of São Paulo, Brazil. It has an approximate area of 22,500 hectares. The land stratification into homogeneous areas, called physiographic units, was performed through the interpretation of aerial photographs in the approximate scale of 1:25,000, the false color composite Landsat TM image (band 5, 4 and 3) in the scale 1:50,000 and radar image - GEMS 1,000 band $X$ - off set copy of semi controlled mosaic in the scale 1:250,000. Each unit was characterized according to descriptive and quantitative elements of drainage and merely descriptive of relief. Through the interpretation elements the grouping analysis 
(Multivariable) was tested in the definition of the groups of physiographic units related to the different kinds of soil. The efficiency of each element in the differentiation of the different groups was also examined through a detailed parametric and non-parametric statistical analysis. From the analysis and discussion of the results obtained the following conclusions can be drawn:

the greatest contribution to the drawing of the superficial drainage network and the delimitation of homogeneous areas was given by the interpretation of aerial photographs followed by the Landsat TM images in relation to the radar images;

the use of analysis of groupings allowed the stablishment of groups of physiographic units related to morphogenetically similar soils;

- $\quad$ stream frequency (among quantitative features), degree of control and angularity (among qualitative features) of the superficial drainage network as well as topographical position, relief kind and class were the most efficient variables in the separation of groups of physiographic units, both in the approximate scale of $1: 25,000$ and the scale of $1: 50,000 ;$

- the relief and superficial drainage network features did not show meaningful results for the separation of groups of physiographic units in the scale of $1: 250,000$. 
the interpretation elements in the several remote sensing products as applied to the study of soils should not be analysed separately but together;

the metodology used in the Cardoso Island State Park is potentially valid in soil surveys at the level of semi-detail with the use of aerial photographs in the approximate scale of $1: 25,000$, at the level of recognition with orbital image in the scale of 1:50,000 and at a more general level with radar image in the scale of $1: 250,000$. 


\section{INTRODUÇÃO}

A utilização de técnicas de sensoriamento remoto em levantamentos do meio biofísico vem assumindo importância cada vez maior, principalmente no que diz respeito ao conhecimento dos recursos naturais, dentre os quais fazem parte os levantamentos geológicos, geomorfológicos, climatológicos, hidrológicos, pedológicos e de vegetação. Esses levantamentos visam orientar a exploração e/ou ocupação de uma forina racional, além de serem um requisito básico para avaliar as potencialidades e estruturar a economia de uma região.

A avaliação das potencialidades para as atividades agropecuárias e florestais depende do conhecimento pedológico, uma vez que as características potenciais e limitações do solo é que determinam o uso, manejo e conservação de uma área, para que a mesma possa ser utilizada com um mínimo de degradação.

Porém, o mapeamento convencional das unidades taxonômicas implica em exaustivos trabalhos de campo, laboratório e escritório, uma vez que envolvem a descrição morfológica de perfis; coleta de material dos horizontes em inúmeros pontos de amostragem; análises químicas, físicas e mineralógicas; processamento e análise de dados; classificação das unidades de mapeamento; para que sejam, finalmente, definidos os limites em uma carta pedológica. 
Neste sentido, o emprego dos diversos produtos fotográficos (fotografias aéreas, imagens orbitais e de rastreamento), isolados ou conjuntamente, podem reduzir o custo e o tempo dos levantamentos de solos, uma vez que através da fotointerpretação pode-se estratificar uma região de estudo em áreas homogêneas quanto ao padrão fisiográfico. Possibilita, desta maneira, o planejamento global das atividades de campo, a redução do número de pontos de amostragem, com consequente diminuição do número de análises e aumento da precisão no traçado dos limites entre as unidades de mapeamento.

As fotografias aéreas têm possibilitado inúmeros trabalhos em pedologia, bem como fornecido meios para o estudo dos parâmetros da rede de drenagem e do relevo que, através de índices numéricos, expressam quantitativamente as diferenças entre tipos ou classes de solos. Com o advento das imagens multiespectrais de pequena escala fornecidas pelo Sistema Landsat-5, bem como dos mosaicos semicontrolados de radar obtidos pelo Projeto RADAMBRASIL, novas perspectivas abriram-se para a pesquisa e monitoramento dos recursos naturais.

Neste contexto a utilização de técnicas e de produtos de sensoriamento remoto têm-se mostrado como importantes ferramentas auxiliares nos mapeamentos de solos de extensas áreas em níveis taxonômicos mais elevados que aqueles possibilitados pelos levantamentos mais detalhados, porém proporcionando um maior rendimento, face às suas peculiaridades, como as da visão sinótica e da característica multiespectral. 
Mas, as abordagens utilizadas para a interpretação de imagens de pequena escala na caracterização dos solos, normalmente, têm sido apoiadas quase que exclusivamente em aspectos qualitativos e descritivos, sem se preocupar em demonstrar quantitativamente, quais os elementos da superfície visíveis, nos produtos sensores, que contribuem para torná-los uma ferramenta valiosa para a compartimentação regional.

Na busca de promover uma ligação mais efetiva entre mapeamentos de solos e sua caracterização fotointerpretativa, é que se elabora esta pesquisa, visando alcançar os seguintes objetivos:

- avaliar a potencialidade das fotografias aéreas, imagens TM/Landsat e imagens de radar, no mapeamento e caracterização de áreas homogêneas quanto aos critérios rede de drenagem e relevo (unidades fisiográficas);

. avaliar o emprego de um método de análise multivariada na definição de grupos de unidades fisiográficas relativos a diferentes tipos de solos;

. analisar a contribuição de vários elementos de interpretação, na definição dos grupos pela análise de agrupamentos; e

- verificar a viabilidade do emprego das próprias unidades fisiográficas no cálculo de índices de drenagem e de relevo. 


\section{REVISÃO DA LITERATURA}

Este capítulo é apresentado dividido basicamente em três partes. A primeira trata da aplicação de fotografias aéreas, a segunda diz respeito a imagens de satélite e a terceira sobre imagens de radar, na interpretação pedológica.

\subsection{Aplicação da Fotografia Aérea: Generalidades}

Em 1840, Arago propõe a utilização de aerofotografias para a elaboração de plantas topográficas, servindo como suporte, a partir de 1850 , para o programa desenvolvido na França por Laussedat.

O uso da fotografia, para definição de roteiros, data desde 1853 e a aplicação da fotogrametria inicia-se ao redor de 1858 por Mcydenbauer, na arquitetura.

Quanto à plataforma aérea, o avião é utilizado pela primeira vez, em 1909, na Itália, mas durante a primeira guerra mundial é que essa técnica teve efetiva evolução e aplicação para espionagem, na Alemanha. Após a grande guerra, a fotografia aérea passa a ser empregada em levantamentos, generalizando-se seu uso nos diferentes ramos da ciência, sendo que o primeiro levantamento de solos realizado com 
o auxílio da fotointerpretação é datado de 1929, elaborado por Bushnell e colaboradores (BOMBERGER \& DILL JÚNIOR, 1960).

Atualmente é indiscutível a importância do uso de fotografias aéreas nos levantamentos de solos. RABBEN (1960), atribui a utilidade da fotografia a três fatores fundamentais:

a) área expressiva abrangida por uma fotografia aérea, ou seja, $33 \mathrm{~km}^{2}$ na escala aproximada de 1:25.000;

b) visão tridimensional da superfície terrestre, através da observação dos pares estereoscópicos; e

c) as imagens dos objetos registrados nas fotografias são permanentes e não tendenciosas, o que permite uma investigação detalhada e cuidadosa da área no momento que o fotointérprete desejar e em condições de rabalho mais cômodas e mais favoráveis do que aquelas da observação direta.

GOOSEN (1968) afirma, com respeito à imagem estereoscópica da paisagem, que esta revela os aspectos principais do terreno de maneira mais eficiente do que aquela observada pela visão normal, devido à exageração vertical proporcionada pela imagem tridimensional. 
A respeito da sensibilidade da imagem fotográfica para o registro dos detalhes do terreno, AB'SABER (1960) salienta que esta propriedade depende muito das condições de clima da região, onde é realizada a cobertura aerofotográfica. Nas regiões de clima seco, o número de informações conseguidas através do exame da fotografia aérea é muito maior do que aquele conseguido das regiões de clima úmido.

Sobre a utilidade da observação estereoscópica, RAY \& FISCHER (1960) afirmam que a forma tridimensional da imagem fotográfica supera os mapas topográficos como fonte de informações, devido à quantidade de detalhes nela contidos. A aerofotografia, contudo, apresenta a limitação de não permitir a visualização dos perfis de solo, mostrando somente a sua superfície e, ainda, de maneira imperfeita.

Para FROST (1960), as interferências na imagem fotográfica, de diferentes naturezas, mascaram as propriedades reais da superfície do solo, tornando a fotointerpretação pedológica completamente diferente daquela de outras áreas de estudo, onde os objetos são parcial ou totalmente vistos na fotografia. Neste caso, os solos somente podem ser interpretados pelo estudo de padrões fotográficos relacionados ao material de origem, ao modo de deposição e aos meios climático, biótico e físiográfico.

\subsubsection{Fundamentos da fotointerpretação}

A fotointerpretação é definida por SUMMERSON (1954), como a previsão do que não pode ser visto, uma vez que as fotografias aéreas não mostram o 
corpo inteiro do solo, apenas a sua superfície e ainda quando esta não é camuflada pela cobertura vegetal, enquanto que QUACKENBUSH (1960) a define como o ato de examinar imagens fotográficas com o propósito de identificar os objetos e avaliar os seus significados.

Considerando que a fotointerpretação de solos é tridimensional e a fotografia não mostra o seu corpo inteiro e sim apenas a paisagem de sua superfície, como formas topográficas, padrões e características de drenagem, de erosão, vegetação e uso, SMITH (1943) afirma que a interpretação dos dados de observação de significância, para solos, depende de um sólido conhecimento do fotointérprete sobre os princípios das ciências que explicam esses fatos.

AVERY (1968) relaciona, dentre os fatores empregados na identificação dos aspectos da fotografia aérea, a forma, tamanho, tom fotográfico, padrão, sombra, posição topográfica e a textura, mas BOMBERGER \& DILL JÚNIOR (1960) consideram estes aspectos como características qualitativas.

Segundo LUEDER (1959), fotoidentificação, fotoanálise e fotointerpretação são técnicas utilizadas no exame da imagem fotográfica. Pela fotoidentificação são reconhecidos os objetos e as suas localizações no terreno; a fotoanálise completa a fotoidentificação pela adição de uma avaliação por numerais e pelo estabelecimento de uma interrelação de aspectos, classificando-os pelos seus tamanhos, posições e usos; e, por último, a fotointerpretação realiza uma avaliação dedutiva e indutiva, baseada na experiência do fotointérprete e nas observações de campo. 
Referindo-se à metodologia para a fotointerpretação, RABBEN (1960), RAY (1963) e RICCI \& PETRI (1965), afirmam que a interpretação de fotografias aéreas é um processo em duas etapas: a primeira, inclui a observação, coleta de dados, medição e identificação de aspectos visíveis nas fotografias, o que corresponderia à fotoidentificação e fotoanálise; a segunda, envolve processos mentais, dedutivos e/ou indutivos usando a informação obtida na solução de um problema, ou seja, na fotointerpretação propriamente dita. Este procedimento é preconizado no Brasil, com sucesso, por FRANÇA (1968), para avaliar a significância das características de redes de drenagem, em termos de diferenças entre solos da região de Piracicaba.

Com respeito às limitações da fotografia aérea nos estudos do solo, GOOSEN (1968) observa que as diferenças entre tipos, fases e, muitas vezes, séries de solos, não são sempre visíveis na superfície terrestre. Isto permite deduzir que, em levantamentos detalhados, a fotointerpretação apresenta valor limitado, o que pode ser verificado pelos critérios e definições de levantamentos, desde os esquemáticos até os detalhados (MARQUES, 1971).

A limitação da utilidade da fotografia na interpretação de solos é sintetizada por FROST (1960), que relaciona os fatores inerentes às técnicas dos materiais fotográficos, às limitações humanas e à própria superfície terrestre fotografada.

Com referência à qualidade da fotografia aérea, Dutton em 1967, citado por GARCIA (1979), ressalta as vantagens da fotografia pancromática na caracterização da paisagem. 
ROURKE \& AUSTIN (1951), PASTO (1953), GUNN (1955), CRESWICK \& ROCKWELL (1959), BOMBERGER \& DILL JÚNIOR (1960), BURINGH (1960) e FRANÇA (1968) reconhecem que a fotografia aérea não substitui completamente o trabalho de campo, embora aumente a exatidão e o rendimento dos mapeamentos de solos, sendo a fotointerpretação mais útil em levantamentos de reconhecimento do que em levantamentos detalhados.

A forma fisiográfica é considerada, por alguns autores, como o elemento mais importante na fotointerpretação de solos, segundo Schutz \& Cleaves, citados por RAY (1963). Contudo, FRANÇA (1968) afirma que é apenas um elemento do padrão dos solos e a interpretação de outros elementos, tais como as características de drenagem ou de erosão, podem fornecer informações igualmente importantes.

Para LUEDER (1959), com exceção da forma fisiográfica, a drenagem superficial é, provavelmente, o elemento mais seguro para identificar um terreno, afirmando que a interpretação da significância de um padrão de drenagem envolve, além dos conhecimentos teóricos do fotointérprete, a experiência para correlacionar detalhes do terreno com a imagem fotográfica.

GOOSEN (1968) apresenta três métodos de fotointerpretação para levantamento de solos: 1) método da análise dos padrões; 2) método da análise dos elementos; e 3) método de análise fisiográfica.

O primeiro deles, método da análise dos padrões, parte da suposição de que cada elemento padrão está relacionado com certas condições do solo. Os elementos 
padrões considerados são a forma do terreno (relevo), a drenagem, os aspectos erosivos, a vegetação, a tonalidade fotográfica e os aspectos culturais. Por este método, a partir da identificação das grandes unidades, se atinge as menores, sendo estas últimas caracterizadas pelos chamados padrões locais.

O segundo// método de análise dos elementos, está fundamentado na análise sistemática dos elementos que se relacionam às condições do solo, cuja classificação resultante é usada como base para o trabalho de campo.

O terceiro método, o da análise fisiográfica, baseia-se num conhecimento profundo dos processos fisiográficos e suas expressões fotográficas. Por este método, o terreno é classificado em unidades fisiográficas, sendo que cada uma delas contém uma particular associação de solos.

COLWELL (1952) afirma que a fotointerpretação deve apoiar-se no princípio da convergência de evidências, segundo o qual, se vários elementos de reconhecimento levam a uma determinada conclusão, esta provavelmente é correta. Para FROST (1960), a fotointerpretação de solos pode ser conduzida à luz de três princípios básicos: a) solos semelhantes aparecem nas fotografias aéreas com padrões semelhantes; b) solos diferentes aparecem com padrões diferentes; c) desde que as características da imagem fotográfica sejam correlacionadas com as propriedades do solo observadas no campo e no laboratório, muitas propriedades importantes de solos semelhantes podem ser inferidas por meio da fotointerpretação. 
Portanto, a medição de dados experimentais é fundamental para a evolução de todos os campos científicos e a fotografia aérea, sendo uma fonte de informações quantitativas, é possuidora de um rico e importante potencial de dados mensuráveis dos aspectos superficiais do terreno. No Brasil, a fotointerpretação pedológica tem se desenvolvido conforme mostram os trabalhos dos pesquisadores: FRANÇA (1968); MARCHETTI (1969); AUDI (1972); FADEL (1972); VASQUES FILHO (1972); LEÃO (1972); GEVAERD (1974); SOUZA (1975); GEVAERD (1976); KOFFLER (1976a); DEMÉTRIO (1977); FREIRE (1977); CARVALHO (1977); ESPÍNDOLA (1977); PIEDADE (1980); POLITANO (1980); CARVALHO (1981); MANECHINI (1981) e PFEIFER (1984).

\subsubsection{Análise morfométrica}

\subsubsection{Padrão de drenagem: tipos, características e significado}

A maneira pela qual os cursos d'água se arranjam ou se distribuem dentro de uma área de drenagem, é expressa pelo termo padrão de drenagem. De acordo com a sua configuração, sugere um modelo, que recebe diferentes designações.

HORTON (1945) adverte que o desenvolvimento de rios e vales em uma dada área pode ser modificado, posteriormente, por estruturas ou episódios geológicos. Isto explica os casos em que se constatam afastamentos das leis dos números e dos 
comprimentos de rios, em condições normais de clima, geologia e solos. Os efeitos de controle de estrutura geológica são constatados por CARVALHO (1977) e PFEIFER \& DOMINGUES (1983/85).

Para TATOR (1954), os padrões de drenagem refletem o controle exercido pela estrutura e tipo de rocha subjacente. Mas para RAY (1963), onde o controle estrutural é mínimo, as características da rede de drenagem são influenciadas pela espessura e natureza do material exposto. Nestas condições, o padrão de drenagem reflete as propriedades do manto de intemperismo e, consequentemente, do solo.

Segundo RICCI \& PETRI (1965), numa área ocupada por determinado tipo de rocha, variações no grau de controle da rede de drenagem podem significar variações na espessura do manto de intemperismo. Para TATOR (1954), as anomalias ou desvios de uma norma do padrão de drenagem regional podem ser tão ou mais importantes para a interpretação do que o próprio padrão.

Como muitos cursos d'água têm suas nascentes em substratos rochosos, cobertos com solos ou mantos espessos, PARVIS (1950), afirma que os padrões de rios de ordens inferiores fornecem indícios pelos quais esses solos ou substratos rochosos podem ser identificados por fotointerpretação, sendo os rios de ordens maiores os que mostram a influência de controles estruturais.

A classificação do padrão de drenagem, segundo LUEDER (1959), tem valor limitado e deve ser complementada com a descrição de certas características, variáveis dentro de cada padrão, podendo indicar aspectos significantes do mesmo. 
Sugere, ainda, a descrição do padrão de drenagem nos seguintes parâmetros: a) grau de integração; b) densidade; c) grau de uniformidade; d) orientação; e) grau de controle; f) angularidade; g) ângulos de confluência; e h) tipo ou designação do padrão.

Segundo FROST (1960), os padrões de drenagem refletem a maneira pela qual a água, que atinge a superfície do solo, se distribui por deflúvio ou infiltração, fornecendo indícios sobre a composição e a origem dos solos.

No entanto, ROURKE \& AUSTIN (1951) afirmam que a forma fisiográfica e o padrão de drenagem são úteis para a identificação e mapeamento de solos. Esta assertiva é confirmada por VERA (1964) no levantamento detalhado de solos efetuado no Chile, no qual o padrão de drenagem é descrito e interpretado em termos de suas principais características e conforme a recomendação de LUEDER (1959).

STRAHLER (1957) desenvolve uma metodologia geomorfológica quantitativa, através da medida de tamanho e elementos geométricos que definem as bacias de drenagem, chamado método de análise dimensional e semelhança geométrica. Segundo FRANÇA (1968), a aplicação do método permite agrupar as bacias de maior similaridade geométrica e, dentro desse contexto, permite inferir sobre a distribuição dos solos ou obter uma maior segurança de homogeneidade dos solos em uma área de estudo.

CARVALHO et al. (1980), aplicando o método de análise dimensional e semelhança geométrica em bacias hidrográficas de terceira ordem de ramificação, 
verifica que bacias hidrográficas de $3^{\mathrm{a}}$ ordem de ramificação quando possuem apenas uma unidade de mapeamento de solo apresentam maior similaridade geométrica.

2.1.2.2. Bacias hidrográficas como critério de estudo da rede de drenagem

Os sistemas fluviais estudados por diversos pesquisadores, principalmente geólogos, geomorfólogos e pedólogos, revelam que as redes de drenagem refletem certas características dos materiais superficiais sobre os quais se desenvolvem. Esta linha de estudo é desenvolvida, inicialmente, em bases descritivas, pois a preocupação é descrever as formas do relevo atual ou identificar a natureza dos solos ou das rochas subjacentes. Obtem-se, como resultado dessas descobertas, a descrição e classificação de muitos padrões de drenagem, procurando sempre correlacioná-los com a natureza dos solos e dos substratos rochosos e/ou com a presença de estruturas geológicas.

HORTON (1945) lança as bases quantitativas para a interpretação de bacias hidrográficas e de suas respectivas redes de drenagem, as quais têm sido aplicadas na identificação e mapeamento de solos com o auxílio de fotografias aéreas, segundo uma aproximação hidrofísica em que se consideram as relações infiltração/deflúvio e os processos erosivos provocado pelas águas correntes. Propõe uma definição para a composição da rede de drenagem e correlaciona o número e o comprimento de rios com as diversas ordens de ramificação da rede, estabelecendo desta maneira, as leis do 
desenvolvimento dos rios e suas bacias, invertendo a notação do sistema europeu de ordem dos rios, descrito por Gravelius, no qual o rio principal é designado como de primeira ordem e os seus tributários imediatos como de segunda ordem e assim sucessivamente. Dessa maneira, a ordem mais alta é a atribuída aos tributários menores, não ramificados.

Com a inversão da sequência de numeração, os tributários menores não ramificados são considerados de primeira ordem, atribuindo a ordem mais elevada ao rio principal, o que facilita a análise e comparação das redes de drenagem, pois somente são comparáveis, entre si, os elementos de mesma ordem de ramificação (HORTON, 1945). Esse sistema é adotado, dentre outros, por STRAHLER (1952), MAXWELL (1955), SCHUMM (1956), CURTIS et al. (1965), FRANÇA (1968), MARCHETTI (1969), FADEL (1972), VASQUES FILHO (1972), LEÃO (1972), GERVAERD (1974), SOUZA (1975), KOFFLER (1976a), DEMÉTRIO (1977), FREIRE (1977) e CARVALHO (1977).

Assim sendo, a lei dos números de rios de HORTON (1945) expressa a relação entre o número de rios de uma dada ordem e a ordem de ramificação, em termos de uma série geométrica inversa, onde a razão de ramificação $(\mathrm{Rb})$ é a base desta série. A lei dos comprimentos de rios expressa a relação entre os comprimentos médios de rios de cada ordem e a respectiva ordem de ramificação, em termos de uma série geométrica direta, na qual, o primeiro termo é o comprimento médio dos rios de primeira ordem e cuja razão é a razão de comprimento médio. 
O mesmo autor afirma que a composição da rede de drenagem tem alto grau de significância hidrológica, enquanto o padrão isolado tem pouca significância; reconhece, contudo, que o padrão de drenagem é altamente significativo como indicador de controle geológico.

SCHUMM (1956) estabelece que a área de uma bacia de drenagem aumenta exponencialmente com o aumento da ordem de ramificação dos rios, à semelhança da lei dos comprimentos de rios estabelecida por Horton. A área é considerada por ANDERSON (1957), como a variável mais importante da bacia hidrográfica, visto que a maioria das outras características da bacia a ela estão relacionadas.

Com referência às variações de área, STRAHLER (1957), além de propor a análise de bacias da mesma ordem de ramificação, preconiza um conceito sobre a similaridade das bacias. Por esse conceito, em bacias geometricamente similares, todas as medidas de comprimento entre os pontos correspondentes conduzem à fixação de uma escala proporcional e todos os ângụlos correspondentes são semelhantes. Segundo este autor, as bacias apresentam similaridade somente nos ambientes onde ocorre homogeneidade de rochas. A vantagem da aplicação deste princípio como base de operação é que, em decorrência, as diferenças da escala linear são independentes da forma ou propriedades da forma da bacia e as diferenças de forma independem das diferenças de tamanho. As dimensões, comprimento, largura, perímetro, relevo, área e volume, são usadas singularmente ou em combinação. 
Poucos padrões de drenagem indicam um desenvolvimento independente da estrutura geológica e, quase todos os padrões conhecidos são respostas ou adaptações à essa estrutura, segundo VON ENGELN (1942).

PARVIS (1950) classifica seis padrões de drenagem básicos: dendrítico, treliça, radial, paralelo, anular e retangular. Utilizando algumas modificações desses seis padrões, classifica e descreve trinta tipos ou modelos. $\mathrm{O}$ autor também se refere a facilidade com que esses padrões de drenagem podem ser observados e analisados em fotografias aéreas, bem como podem representar uma avaliação significativa na fotointerpretação de solos e substratos rochosos.

STRAHLER (1957) aplica a lei dos números de rios de Horton para comprimento totais de rios, expressando a relação entre o comprimento total de rios, de uma dada ordem de ramificação, em termos de uma série geométrica inversa, onde a razão de comprimento total é a base desta série.

O mesmo autor constata que há uma relação inversa entre os valores da densidade de drenagem, ao verificar que com o aumento do valor da densidade de drenagem, ocorre uma diminuição quase que proporcional dos tamanhos dos componentes fluviais das bacias de drenagem, resultados estes comprovados por CHRISTOFOLETTI \& CESAR (1978), os quais observam uma menor significância dessa relação com o aumento do número de ordem das bacias.

Para ZINKE (1960), a densidade de drenagem é função da precipitação pluviométrica e da capacidade de infiltração, podendo ser considerada uma descrição física quantitativa da bacia hidrográfica. 
HORTON (1945) propõe duas relações para expressar quantitativamente o grau de desenvolvimento da rede de drenagem de uma bacia hidrográfica: a densidade de drenagem (Dd) e a frequência de rios $(F)$. A densidade de drenagem (Dd) vem a ser o comprimento médio dos rios por unidade de área e é expressa pela equação:

$\mathrm{Dd}=\mathrm{Lt} / \mathrm{A}$ onde, $\mathrm{Lt}$ é o comprimento total de rios das diversas ordens e A é a área, ambos expressos em unidade do mesmo sistema.

A frequência de rios $(F)$, é expressa pela equação:

$\mathrm{F}=\mathrm{N} / \mathrm{A}$ onde, $\mathrm{N}$ é o número de rios das diversas ordens e $\mathrm{A}$, a área da bacia de drenagem.

Segundo RAY (1963) a densidade de drenagem em um dado ambiente climático, relaciona-se principalmente, com a resistência à erosão dos materiais, pois a densidade aumenta a medida que diminui a resistência à erosão. Com o exame de fotografias aéreas conclui que os folhelhos e outras rochas similares, de granulação fina, tendem a apresentar drenagem de textura fina e que os arenitos de granulação grosseira tendem a apresentar drenagem de textura grosseira, mas admite que podem ocorrer exceções. 
Para HORTON (1945) e STRAHLER (1957) a densidade de drenagem e a frequência de rios variam com o tamanho da área da bacia, não podendo haver comparação entre pequenas e grandes bacias, através dessas duas relações.

Segundo STRAHLER (1957), é indispensável comparar bacias que tenham a mesma ordem de ramificação para que se possa obter dados significativos.

O mesmo autor, utilizando o princípio da análise dimensional e semelhança geométrica, tenta elaborar um sistema de geomorfologia quantitativa, baseado em que, se houver uma semelhança geométrica aproximada entre duas bacias, todas as medições de comprimento entre pontos correspondentes manterão uma razão de escala fixa.

Para expressar o espaçamento entre canais de drenagem em mapas topográficos com curvas de nível, SMITH (1950) propõe uma relação denominada razão de textura. Como geralmente os canais menores não são representados nos mapas topográficos, as suas localizações, em tais mapas, podem ser identificadas pelas inflexões das curvas de nível. Recomenda então, que se escolha a curva de nível com o maior número de inflexões e que se divida esse número pelo perímetro da bacia, obtendo-se assim a razão de textura, expressa pela fórmula:

$\mathrm{T}=\mathrm{N} / \mathrm{P}$ onde, $\mathrm{T}$ é a razão de textura, $\mathrm{N}$ é o número de inflexões da curva de nível escolhida e P é o perímetro da bacia.

Conforme recomendam HOWE (1960), RAY (1963) e RICCI \& PETRI (1965), os sistemas de drenagem podem ser melhor estudados em mapas básicos de 
drenagem obtidos pelo exame estereoscópico de fotografias aéreas. Em vista disso, FRANÇA (1968) faz a determinação da textura topográfica considerando $\mathrm{N}$ como sendo o número total de rios da bacia segundo HORTON (1945), ou o número de segmentos de rios de $1^{\mathrm{a}}$ ordem de ramificação segundo o sistema de STRAHLER (1957).

Para caracterizar a textura topográfica de uma dada área como um todo, levando em consideração o tamanho de cada bacia, SMITH (1950) propõe o uso do valor médio ponderado, que pode ser determinado através da seguinte fórmula:

$\mathrm{Tm}=\Sigma(\mathrm{A} . \mathrm{T}) / \Sigma \mathrm{A}$ onde, $\mathrm{Tm}$ é o valor médio ponderado da razão de textura topográfica, $\mathrm{A}$ representa a área de cada bacia $\mathrm{e}, \mathrm{T}$ a razão da textura topográfica de cada bacia.

Para a classificação da textura topográfica, SMITH (1950) propõe que os parâmetros, referente a comprimentos de perímetro, devem ser expressos em milhas; contudo, FRANÇA (1968) propõe a equivalência, referente a perímetro, expressa em quilômetros.

Segundo FRANÇA (1968), quando aumenta a ordem de ramificação de uma rede de drenagem, ocorre o aumento na área de drenagem e variação das características quantitativas do padrão (aumenta a razão da textura e diminue a densidade de drenagem e a frequência de rios), porque aumentando a área da bacia, o perímetro aumenta de um modo proporcionalmente menor. 
2.1.2.3. Amostras circulares como critério de estudo da rede de drenagem

Em 1960 é apresentado o critério de amostras circulares para ser empregado no estudo de redes de drenagem, para fins de caracterização litológica, sendo adotadas amostras com tamanho equivalente a uma área de $10 \mathrm{~km}^{2}$ (RAY \& FISCHER, 1960).

Porém para BURINGH (1960), as amostras circulares podem apresentar variação de tamanho equivalente a uma amplitude de 10 a $100 \mathrm{~km}^{2}$, dependendo da escala utilizada.

Nos estudos de solos, FRANÇA (1968) aplica a metodologia e obtem resultados significativos para a densidade de drenagem de amostras circulares. Aponta as seguintes vantagens:

a) eliminação da influência da área, uma vez que todas as medições de comprimento de rios são referentes à mesma área circular de 10 km²;

b) a área circular de amostragem pode ser deslocada dentro da área de ocorrência de uma unidade de solo, sem consideração dos limites de bacias hidrográficas, procurando abranger unicamente a maior proporção e a maior homogeneidade possíveis da unidade que é amostrada. 
Os resultados de França são confirmados por MARCHETTI (1969), FADEL (1972), VASQUES FILHO (1972), LEÃO (1972), GEVAERD (1974), GARCIA (1975), KOFFLER (1976a), FREIRE (1977), CARVALHO (1977), POLITANO (1980), MANECHINI (1981) e PFEIFER (1984).

Com respeito a variação do tamanho das amostras, os trabalhos de SOUZA (1975), KOFFLER (1976b), FREIRE (1977) e POLITANO (1980) permitem constatar que a utilização de círculos, com tamanho equivalente a $5 \mathrm{~km}^{2}$ de área, propiciam uma melhor representação dos solos nos casos em que a conformação da área de ocorrência limita a tomada de amostras de maior tamanho.

Com o intuito de comparar o estágio evolutivo de voçorocas existentes em duas áreas do município de Botucatu (SP), PIEDADE (1980) estuda fotointerpretativamente, bacias hidrográficas de $3^{\mathrm{a}}$ ordem de ramificação, extraídas de rede de drenagem de - Regossol "intergrade" para Latossol Vermelho-Amarelo e "intergrade" para Podzólico Vermelho-Amarelo (RPV - RLV) e Latossolo VermelhoAmarelo - fase arenosa (LVa), utilizando de fotografias aéreas de 1962, 1972 e 1977. Conclui que o valor médio da integral hipsométrica associada à forma das curvas representadas no diagrama, com presença de testemunhos de erosão, sugerem para a área com RPV-RLV um estágio mais jovem de relevo (retomada de erosão), enquanto que para a área com LVa um relevo mais maduro.

Próximo a área, no município de São Manuel, SILVA (1988) estuda o comportamento da rede de drenagem, através de amostras circulares de $10 \mathrm{~km}^{2}$, 
extraídas de LVa, TE e RPV-RLV, das fotografias aéreas na escala aproximada 1:25.000, concluindo que as variáveis da rede de drenagem contribuem na discriminação dos solos com similaridade morfogenética (RPV-RLV e LVa), quando analisados conjuntamente com os de relevo; a densidade de drenagem é mais eficiente para a diferenciação dos referidos solos, o que concorda com CARDOSO (1988) que também estuda o mesmo comportamento da rede de drenagem, na mesma região, de duas áreas reflorestadas com eucalipto; inferindo sobre a diferenciação das unidades taxonômicas (análise multivariada) utilizando-se de bacias hidrográficas de $3^{\mathrm{a}}$ ordem de ramificação e amostras circulares de $10 \mathrm{~km}^{2}$.

Ainda comprovando a mesma metodologia, CARVALHO et al. (1990) avaliam a ação conjunta dos parâmetros da bacia hidrográfica, da rede de drenagem e do relevo, determinados em bacias hidrográficas de $3^{\text {a }}$ ordem de ramificação, representativas das unidades de mapeamento RPV-RLV, LVa e Lib.

\subsection{Imagens Orbitais Aplicadas ao Estudo de Solos}

\subsubsection{Generalidades}

O experimento fotográfico desenvolvido pelos astronautas da espaçonave Appolo 9, em março de 1969, segundo KOFFLER (1976a), proporciona aos pesquisadores, pela primeira vez na história, fotografias espaciais de alta qualidade para 
uso específico no estudo dos recursos da terra, os quais observam também que os principais fatores que tornam as fotografias orbitais diferentes das familiares fotografias aéreas são: escala pequena; grande área coberta por apenas uma fotografia e uso de plataformas situadas a centenas de quilômetros acima da superfície terrestre.

Desta forma, a grande área coberta por uma fotografia orbital permite reconhecer grandes feições, impossíveis de se observar em outras circunstâncias como, por exemplo, sistemas de drenagem completos.

Entretanto, o grande impulso no estudo de recursos naturais de nosso planeta, a partir de imagens obtidas de plataformas orbitais, é dado com o lançamento pelos Estados Unidos do $1^{0}$ satélite tecnológico para recursos da Terra, ERTS-1, em 23 de julho de 1972, rebatizado posteriormente para LANDSAT-1.

Desde essa época a superfície da terra passa a ser imageada contínua e sistematicamente a intervalos de 18 dias pelos 3 primeiros satélites da série e de 16 dias pelo Landsat 4 e 5 .

A cada novo lançamento são incorporados avanços tecnológicos na área de sensores remotos, de tal forma que a qualidade das imagens está gradativamente, se aproximando aos das tradicionais fotografias aéreas. O sistema SPOT (francês) já proporciona até imagens com sobreposição para visão tridimensional, embora pouco operacional devido à grande altitude da plataforma.

As imagens orbitais, atualmente, apresentam tanto vantagens como limitações, com relação a fotografia aérea. 


\section{Vantagens:}

I. análise de grandes áreas em apenas uma imagem. No sistema Landsat, uma imagem de $185 \mathrm{~km} \times 185 \mathrm{~km}$ abrange mais de 3,4 milhões de hectares;

II. repetitividade - novas imagens de uma área a cada 16 dias;

III. disponibilidade - pode dispensar a realização de levantamentos aerofotogramétricos; IV. custo - o $\mathrm{km}^{2}$ é mais barato; $\mathrm{e}$

V. homogeneidade - toda a área coberta pela imagem apresenta-se uniforme, o que seria difícil obter com as centenas de aerofotografias necessárias para cobrir área semelhante.

\section{Desvantagens:}

I. é difícil o mapeamento de detalhes, sendo mais recomendadas para estudos regionais; e

II. ausência de estereoscopia - o relevo e outras feições topográficas devem ser inferidos pela análise da drenagem superficial, textura fotográfica, erosão, diferenças tonais e sombras.

Atualmente, além do Landsat-5, dispõe-se do satélite, SPOT-1, desenvolvido pelo consórcio entre França, Bélgica e Suécia, lançado em 22 de fevereiro de 1986. 
Com os dados orbitais, mais um elemento de análise de imagens é colocado à disposição do fotointérprete: a dimensão temporal, que permite analisar a variação das características de objetos da superfície terrestre ao longo do tempo.

Existem, ainda, projetos de outros satélites a serem lançados futuramente por outros países, inclusive o Brasil, o que garante a disponibilidade de imagens orbitais atualizadas.

Conforme YOUNG (1976), a principal contribuição do sensoriamento remoto em levantamentos de solos, em adição às fotografias aéreas convencionais, provém das imagens de satélite. Comenta que é improvável que as imagens de satélite venham a competir com as fotografias aéreas, em aspectos para as quais estas últimas são tecnicamente mais adequadas e corretamente utilizadas, como interpretações em escalas médias e grandes, envolvendo a visão estereoscópica de aspectos fisiográficos do terreno; para levantamentos desse tipo, as imagens são um complemento, porém não um substituto das aerofotografias e que as imagens abrem possibilidades para levantamentos de recursos naturais, em pequenas escalas, de países com grande extensão territorial, como o Brasil. Essa opinião é compartilhada por VALÉRIO FILHO et al. (1981).

Para WESTIN (1973), os perfis de solo não são vistos, quer seja nas fotografias aéreas, quer nas imagens orbitais; mesmo a superfície do terreno, na maior parte das vezes, está coberta por vegetação. Assim o reconhecimento e delimitação das 
unidades de solo podem ser realizados com base no tipo de vegetação, material de origem dos solos, relevo e rede de drenagem.

SIEGAL \& GOETZ (1977), estudando a influência da vegetação sobre a identificação de solos e rochas nas imagens, comentam que a cobertura vegetal natural pode mascarar e alterar significativamente a resposta espectral da superfície terrestre, medida por varredores multiespectrais a bordo de aeronaves ou satélites. Concluem que a significância da cobertura vegetal depende da quantidade e tipo de vegetação e da reflectância espectral da superfície. Materiais de baixo albedo são os mais significativamente afetados e o seu reconhecimento pode ser prejudicado com apenas $10 \%$ de cobertura vegetal verde.

Dados Landsat processados digitalmente, feita uma estratificação preliminar segundo a paisagem (fisiografia) e materiais de origem, são úteis para ROUDABUSH et al. (1985) na delimitação de áreas homogêneas em termos de solo, facilitando muito o posterior trabalho de campo, como a descrição das unidades taxonômicas e da vegetação. Segundo esses autores, o uso de dados do Landsat resulta em economia de tempo e dinheiro, bem como melhora a qualidade dos levantamentos, no que se refere à idenficação dos limites entre as unidades de solo, assim como ocorre com a utilização de fotografias aéreas.

Segundo BALEANI \& RAED (1986) a informação proporcionada pelos satélites, juntamente com a análise digital, constituem uma primeira aproximação na discriminação espacial do estado do solo, baseada em sua textura, rugosidade, conteúdo 
de matéria orgânica, óxido de ferro e umidade. Concluem que a combinação da análise digital de imagens MSS/Landsat com técnicas convencionais de levantamento permite bons resultados no mapeamento de solos, uma vez que possibilita determinação rápida e precisa dos grandes ambientes em nível de semidetalhe.

WESTIN \& FRAZEE (1976) verificam que os dados Landsat são aplicáveis aos levantamentos de solos pelas seguintes razões: visão sinóptica do terreno; disponibilidade de dados multiespectrais; possibilidade de obtenção de dados temporais e projeção quase ortogonal.

GIMBARZEVSKI (1974a) comenta que as imagens fornecidas pelo sistema Landsat apresentam vantagens e limitações. A pequena escala proporciona uma visão global de áreas extensas, porém limita o mapeamento de certos detalhes importantes. A falta de estereoscopia é uma séria limitação ao reconhecimento de feições topográficas do terreno e as informações sobre características físicas da superfície têm que ser inferidas através da análise dos padrões de drenagem superficial, textura, erosão e efeito de sombreamento.

Conforme GIMBARZEVSKI (1974b), PACHECO \& HOWARD (1977), SEGOVIA et al. (1980) e COCHRANE \& BROWNE (1981) a visão global de áreas extensas, proporcionada pelas imagens orbitais de pequena escala, possibilita a compartimentação de paisagens contíguas com distintos padrões de relevo, estrutura geológica, evolução geomórfica e vegetação regional, proporcionandơ assim o reconhecimento de importantes componentes destes padrões. 
MONTOYA (1977), trabalhando com diferentes produtos fotográficos (fotografias aéreas, imagens Landsat e de radar), conclui que as unidades da paisagem podem ser identificadas e delineadas nos três tipos de sensores, e que os elementos de interpretação como relevo, vegetação e rede de drenagem, são muito úteis como auxilares na identificação das unidades fisiográficas associadas aos solos.

\subsubsection{Rede de drenagem superficial}

À semelhança do que ocorre com a interpretação de fotografias aéreas, tanto a rede de drenagem superficial quanto o relevo têm-se mostrado como critérios úteis à interpretação visual de imagens orbitais aplicada a levantamentos de solo.

Tanto assim que CARTER \& STONE (1974) comentam que o procedimento utilizado para interpretar fotografias aéreas pode ser aplicado na interpretação de imagens orbitais ou, segundo VALÉRIO FILHO et al. (1981), através de fotopedologia adaptada à análise de imagens multiespectrais de pequena escala.

GARCIA et al. (1981), trabalhando com fotografias aéreas, imagens Landsat e de radar, avaliam a eficiência dos padrões de drenagem e vegetação no mapeamento, de 100.000 ha, de solos do Estado de São Paulo. Concluem que as imagens de radar são mais eficientes no estudo dos padrões de drenagem e fisiografia de áreas extensas, enquanto que as imagens de satélite (MSS/Landsat) destacam-se no 
estudo da cobertura vegetal, embora as fotografias aéreas tenham-se demonstrado o material mais preciso para ambos os casos.

MARCHETTI \& GARCIA (1990), reunindo as três metodologias conhecidas para o estudo de solos, todas associadas às técnicas de sensoriamento remoto, para uma mesma área, relacionam os solos com seus parâmetros espectrais obtidos digitalmente de imagens de satélite no estudo dos índices de drenagens e de vegetação. Para cada situação prepararam um mapa de solos, que se aproximava do mapa já existente e quando as informações de tais mapas foram agregadas em um único mapa, a aproximação com a carta de controle foi altamente satisfatória, evidenciando a aplicabilidade da metodologia.

VETTORAZZI (1988), através da interpretação das imagens bandas TM3, TM-4 e TM-5, nas escalas 1:100.000 e 1:250.000, estratifica o terreno em áreas homogêneas, com relação aos critérios rede de drenagem e relevo denominando-as de unidades fisiográficas. Testa a análise de agrupamentos (multivariada) na definição de grupos de unidades fisiográficas referentes a diferentes tipos de solos e conclui que o emprego conjugado de imagens de três bandas diferentes é de grande utilidade na delimitação das unidades fisiográficas, para ambas as escalas e que os critérios rede de drenagem e relevo têm comprovada a sua eficiência na interpretação visual de imagens, visando a estratificação regional em áreas fisiograficamente distintas.

COVRE et al. (1986) fazem uma análise comparativa entre índices de drenagem extraídos de fotografias aéreas verticais e de imagens TM/Landsat analisando 
os seguintes índices: densidade de drenagem, frequência de rios, comprimento médio de rios e razão de textura. Embora a extração das informações de drenagem tenham sido obtida através de visão estereoscópica para as aerofotografias e visão monoscópica para as imagens, os resultados demostram pequena diferença quantitativa para os índices de drenagem analisados. Porém, verificam que as imagens TM/Landsat não são tão eficientes quanto as fotografias aéreas na detecção de canais de primeira ordem e cabeceiras de erosão, fato constatado anteriormente por outros autores, ao trabalharem com os mesmos propósitos (KOFFLER, 1976 a; TOWNSHEND et al., 1979 e EPIPHANIO et al., 1983).

Estudando características quantitativas do padrão de drenagem, NOGUEIRA (1979) conclui ser a densidade de drenagem o índice mais eficiente na diferenciação entre unidades de solo, conclusão esta obtida também por SOUZA (1975), VALÉRIO FILHO (1984) e SILVA (1988). Entre os que concluem ser a frequência de rios um índice mais eficiente na separabilidade de unidades de mapeamento, encontramse dentre outros, CARVALHO (1977 e 1981), GUIMARÃES (1984), PFEIFER (1984) e VETTORAZZI (1985).

Porém VALÉRIO FILHO et al. (1981) alertam para o fato de que "não se deve esperar que através das imagens Landsat seja possível a total restituição da drenagem, como a que se consegue com o uso de fotografias aéreas, mas é possível reconhecer a rede de drenagem a um nível compatível com a escala de trabalho". 


\subsubsection{Elementos do relevo}

Outro importante critério na interpretação visual de imagens orbitais é o relevo. CARNEIRO (1975), trabalhando com imagens Landsat no mapeamento de solos, conclui que o relevo exerce forte influência sobre os demais critérios de interpretação, como a tonalidade e a textura topográfica.

VALÉRIO FILHO (1984) avalia a contribuição de determinados índices de drenagem e de relevo, extraídos de fotografias aéreas e cartas topográficas, na diferenciação de cinco tipos de solos, contidos em unidades fisiográficas previamente mapeadas com o auxilio de imagens Landsat e mosaicos de radar. Conclui que os índices de relevo, de uma maneira geral, são mais eficientes que os índices de drenagem na discriminação dos solos.

A valiosa contribuição que os atributos do relevo fornecem na diferenciação entre solos têm sido estudado por diversos autores, entre os quais MARCHETTI (1969), POLITANO (1980), KOFFLER (1982), LEÃO (1983), ANGULO FILHO (1986) e SILVA (1988).

Porém, GIMBARZEVSKY (1974 a) cita que as feições do relevo não são reconhecidas diretamente através da visualização das imagens orbitais, mas podem ser inferidas através da análise das feições, de padrões de drenagem, erosão, diferenças tonais e, em alguns casos, em função dos efeitos de sombra. 
O sombreamento nas imagens Landsat pode ser usado como indicação de que a área é ondulada, colinosa ou montanhosa. Subdivisões podem ser baseadas no comprimento e percentual de sombras, levando-se em consideração a orientação das colinas e montanhas para com o ângulo de elevação solar, que varia com a época do ano (PACHECO \& HOWARD, 1977).

Com relação ao baixo ângulo de elevação solar, WLAKER \& TREXLER (1977) verificam que a utilização de imagens assim obtidas, têm demonstrado ser de grande utilidade em levantamentos geológicos e pedológicos, isto porque o efeito do realce das sombras e das vertentes iluminadas, isto é, o efeito produzido pelas áreas, sombreadas e iluminadas, é um indicador útil no reconhecimento das variações topográficas, o que concorda WESTIN \& BRANDNER (1980).

\subsubsection{Tonalidade e textura fotográfica}

Os tons ou nuances na imagem são o resultado da quantidade de luz refletida pelos objetos. A grosso modo, objetos escuros refletem menos luz que objetos claros.

De um modo geral, solos orgânicos e argilosos têm mais umidade, conferindo cores mais escuras às imagens. Solos Gleizados são facilmente mapeáveis por esse critério, além do relevo plano de ocorrência. Solos alcalinos de regiões áridas aparecem com manchas claras quando secos e com manchas escuras com bordas brancas quando úmidos. 
Assim sendo, elementos como relevo, rede de drenagem e uso da terra, influenciam diretamente a textura fotográfica da imagem.

Para CARTER \& STONE (1974), a textura fotográfica é a frequência da mudança de tonalidade sobre a imagem. Este elemento de reconhecimento é produzido por um agregado de alvos de diferentes tonalidades, os quais também são muito pequenos para serem vistos individualmente. Portanto, a escala determina a textura e, desta forma, o que pode ser identificado como feição individual sobre fotografias de grande escala, pode ser visível somente como textura em imagens Landsat com vantagens sobre as fotografias aéreas convencionais, pois as feições que normalmente são padrões nas aerofotografias, aparecem como textura fotográfica nas imagens orbitais.

CHRISTOFOLETTI (1974) verifica que um aumento nos valores de declividade do terreno, provoca um aumento nos valores de textura topográfica e densidade de drenagem. Aspecto este que concorre para influenciar a textura fotográfica nas imagens Landsat, conforme é corroborado por VALÉRIO FILHO et al. (1976) e por KOFFLER (1976 b), devido à relação textura fotográfica na imagem Landsat e condições topográficas.

NOVO (1983) verifica que a inspeção visual de uma mesma cena tomada a diferentes ângulos de elevação solar e de azimute, evidencia que as mesmas feições do terreno são registradas segundo diferentes padrões de tonalidade e textura; e que as imagens com baixo ângulo de elevação solar e azimutes relativamente altos determinam o aumento do número de classes geomórficas distintas. 
Trabalhando com esses aspectos, DONZELI et al. (1983) concluem que o uso de imagens Landsat e de Radar, na escala 1:250.000, é compatível com a definição de mapeamento de solos em nível de reconhecimento com detalhes, sendo comprovada a estreita correlação enłre o mapeamento de unidades fisiográficas por fotointerpretação e o mapeamento convencional de solos nesse nível. Concluem, ainda, que as conjugações das imagens - RBV/Radar e MSS-7 permitem resultados mais satisfatórios na definição das unidades fisiográficas, por fornecerem informações de natureza complementar; as imagens RBV destacam os aspectos da rede de drenagem e tonalidades fotográficas, enquanto que as imagens de Radar e MSS-7 contribuem com o aspecto do relevo e textura fotográfica.

\subsection{Imagens de Radar Aplicadas ao Estudo de Solos}

Dentre os sistemas sensores empregados para levantamentos dos recursos naturais, dos quais os mapeamentos pedológicos fazem parte, o RADAR ("Rádio Detection And Ranging") oferece um ângulo de cobertura amplo, a capacidade de imageamento em lugares de pouca visibilidade, o destaque das feições topográficas resultante da visada oblíqua e informações relativas a variações do terreno e relevo local, através da textura e do efeito de sombra das imagens (PARRY, 1974).

O Radar foi criado no início da década de 50 para designar um equipamento militar usado na detecção de longo alcance de navios e aviões. 
O princípio básico de funcionamento é a emissão de micropulsação, que pode ser contínua ou de um pulso por vez, o que é mais comum, com captação do retorno, que irá variar segundo os objetos sobre as quais incidir.

Genericamente, segundo MOORE \& SIMONETT (1967), existem dois tipos fundamentais de radar, quais sejam: o de emissão não coerente e o de emissão. O último tipo é o radar de abertura sintética ou "Doppler", que faculta a emissão polarizada.

Segundo WONG et al. (1977) um sistema de radar tem o seguinte esquema básico : fonte de força - transmissor de micropulsação - antena - receptor de micropulsação - tubo de raios catódicos - filme.

A faixa de radar, no espectro eletromagnético, está dividida em diferentes bandas, designadas por letras, das quais a mais adequada para estudos detalhados é a chamada Banda $K$, entre frequências de 10.900 e 36.000 megaciclos e comprimentos de ondas entre 2,7 e 0,8 cm (ANDREWS, 1966).

A Banda $\mathrm{K}$ registra características da vegetação, enquanto outra, a Banda P, entre 220 - 390 megaciclos e comprimentos de ondas entre $136-77 \mathrm{~cm}$, penetra através da vegetação, dando um retorno que permite registro, meio a meio, das características do solo e da vegetação (ROUSE et al., 1965 e ANDREWS, 1966).

As imagens disponíveis em nosso meio são obtidas pelo sistema do tipo abertura sintética, Banda $X$, entre frequências de 3.000 a 12.500 megahertz $\left(10^{6}\right.$ ciclos/s) e comprimento de ondas entre 2,4 a $3,8 \mathrm{~cm}$, produzidas pelo Projeto RADAMBRASIL (1983) para o levantamento de recursos naturais do Brasil. 
O radar vem sendo estudado para diferentes aplicações (MORAIN \& SIMONETT, 1966), havendo ocorrido um grande aperfeiçoamento nas imagens obtidas e, mesmo, dando origem a nova técnica, a da Radargrametria, similar à Fotogrametria, mas específica para imagens de radar e que exige métodos e aparelhos especiais.

Uma das suas principais características é a faculdade de permitir obter imagens através de polarização, que pode ser horizontal, vertical ou elíptica.

Mencionam-se como principais vantagens do radar, as seguintes: atuação em qualquer condição de tempo; não depende de horário; velocidade na coleta de dados (mais de $180.000 \mathrm{~km}^{2} / \mathrm{dia}$, ou seja, 36 horas para recobrir todo o Estado de São Paulo); amplas áreas de recobrimento e pequenas escalas de apresentação de 1:1.000.000 até 1:300.000 ou maiores (MORAIN \& SIMONETT, 1966).

Nas imagens convencionais, as variações tonais são funções das reflexões difusas da luz, e no radar, as imagens são compostas por grande número de reflexões especulares.

A interpretação das imagens de radar, primariamente, repousa na classificação dos tipos gerais de dados pictórios, como função direta das propriedades de reflexão dos componentes naturais e culturais do ambiente.

Segundo a reflexão, as seguintes características são discerníveis: áreas de alto retorno, que produzem imagens negativas claras; áreas de moderada energia, imagens pálidas; áreas de baixa energia, imagens cinza médio e áreas sem retorno significativo, com imagens escuras (THE AMERICAN SOCIETY OF PHOTOGRAMMETRY, 1966). 
Assim, de forma antagônica às fotografias convencionais, nas quais as características do terreno são reconhecidas por transposição de aspectos familiares, fundamentalmente, a aparência em imagens de radar deriva de reflexão da energia eletromagnética, após alterações devidas às propriedades específicas dos materiais.

A fase de imagens de radar com pequena resolução é superada com o chamado radar de visada lateral, associado ao conjunto emissor de pulsos simultâneos e processamento adequado dos sinais de retorno.

O sistema que produz imagens baseia-se em linha de emissão sensoriadora radial, cobrindo ângulo de $360^{\circ}$. Por esta razão, em radar fala-se em resoluções azimutal e radial, cujo produto define a área coberta por um sinal. Neste caso, a expressão resolução define o tamanho mínimo discernível, em metros.

Outra importante característica do radar está no fato de que, sendo um sensor ativo, produz sua própria iluminação, o que requer vôos com recobrimentos laterais no mesmo sentido, para evitar o efeito das sombras de radar, que prejudicam a interpretação (COELHO, 1972).

O sistema utiliza princípios e recursos da televisão para obtenção das imagens, que podem constar em diapositivos ou cópias em papel, de forma contínua, como no imageador.

Elementos aéreos e terrestres têm influências diretas sobre as imagens resultantes, principalmente: 
a. elementos aéreos - ângulos de incidência; comprimento de onda e polarização. b. elementos terrestres - propriedades dielétricas do material à superfície do terreno; rugosidade do terreno e topografia.

Segundo EGAN \& HALLOC (1966), a polarização é um fenômeno muito importante, sendo que os materiais terrestres têm características polarizadoras nas luzes refletidas e emitidas. Estas, são funções da fase (incidente + emergente) e dos ângulos de vista (emergentes) da superfície, assim como do campo espectral.

Portanto existem vários sistemas de radar, porém o mais utilizado em estudos de solos é o Radar de Visada Lateral no qual, segundo CREPANI (1983), a antena que emite o pulso de radar, recebe o sinal de retorno refletido pelo terreno, enviando este sinal para um sistema eletrônico que o transforma em sinal elétrico que, por sua vez, passa por um tubo de raios catódicos, gerando um sinal luminoso, o qual impressiona o filme fotográfico.

Para NUNNALY (1969), as imagens de radar possibilitam meios para a delimitação de várias associações de fenômenos físicos e culturais, através das variações nas feições da imagem, evidenciadas pela tonalidade, textura, padrão e forma.

BARR \& MILES (1970) comentam que a tonalidade e a textura são os elementos interpretativos mais importantes no estudo da imagem de radar, relatando inclusive, que os respectivos mapas de drenagem apresentam a mesma significância de mapas obtidos de aerofotografias convencionais. Entretanto, a aparência e o nível de 
detalhe geral do padrão de drenagem obtido pela imagem de radar é diferente. Esta é também a opinião de Delwing citado por VALERIO FILHO (1984), o qual afirma que o nível de informação é controlado pela escala da imagem, pela resolução do sistema e pelos aspectos superficiais de visibilidade dos canais de drenagem.

Os canais de primeira ordem normalmente não são registrados pelo Radar de Visada Lateral, devido a escala e resolução, o que diminui o valor da análise do padrão de drenagem para condições locais, mas sua influência é menor quando a avaliação é em nível regional (BARR \& MILES, 1970).

KOOPMANS (1973), analisando imagens de radar ampliadas para a escala 1:88.000, também conclui que os elementos da drenagem extraídos pela interpretação monoscópica não fornecem dados precisos para a realização de estudos quantitativos, face à perda de informação, principalmente dos canais de primeira ordem, provando portanto, ser de pouco valor para a análise de drenagem, principalmente, para áreas de relevo mais movimentado, opinião esta compartilhada por KOFFLER (1976 b) e EPIPHANIO et al. (1983).

Porém, para GARCIA (1979), no estudo das possibilidades das técnicas de sensoriamento remoto, na avaliação do potencial de uso de regiões de cerrado, é possível a delimitação de associações de solos em nível generalizado, através da rede de drenagem demarcada a partir de imagens de radar.

PARRY (1974) adverte que o radar tem a vantagem adicional em estudos dos aspectos do terreno pelo fato de que a re-irradiação advinda da superfície é, em 
parte, um processo de espelhamento. Desta forma, há uma relação direta entre a rugosidade da superfície e a consequente textura registrada nas imagens. Esta relação não é encontrada em outros sistemas sensores e é, obviamente, de grande eficiência em análises de feições do terreno.

De acordo com BARR \& MILES (1970) a distribuição média do elemento tonal, a textura individual e a combinação de ambos formam o padrão topográfico e as variações topográficas do terreno imageado afetam a distribuição do sombreamento provocado pelas encostas sem retorno do sinal, com grande frequência de ocorrência de sombras que caracterizam a rugosidade do terreno. Assim sendo, a avaliação das condições topográficas através de imagens de radar é menos precisa quando se procura determinar suas dimensões, se comparada à contribuição dada pelas fotografias aéreas com o recurso da estereoscopia.

Porém o uso de baixos ângulos de elevação solar, quando combinados com aumentos de contraste de material impresso, pode reproduzir algumas das feições das imagens de radar, como o sombreamento topográfico, o que faz com que as imagens de radar sejam úteis para aplicações nas áreas de geologia, pedologia e geomorfologia (LYON et al., 1970).

O sombreamento proporcionado pelas imagens de radar, conforme PARRY (1974), destaca as pequenas feições do relevo, proporcionando o realce destas, as quais são comparáveis com as fotografias obtidas com baixo ângulo de elevação solar. Particularmente, isto é expressivo em áreas de topografia suave, onde variações sutis na textura topográfica e feições de pequena escala são reconhecidas nas imagens. 
Segundo SIMONS (1964) a perspectiva proporcionada pelos efeitos de sombra do radar enfatizam aspectos relativos ao relevo e pela graduação tonal causada pela variação das características do retorno do sinal de diferentes superfícies litológicas, solos e padrões culturais, permitindo uma rápida caracterização destas feições.

GARCIA (1979), trabalhando com imagens Landsat e de Radar no estudo de vegetação e solos, verifica que ambas são altamente eficientes e sugere que maior atenção deve ser dada à aplicação conjugada destas fontes de informações, o que é corroborada por DONZELI et al. (1983), os quais concluem que a conjugação de imagens de Radar e de RBV/Landsat é a mais eficiente no mapeamento de unidades fisiográficas distintas, as quais estão associadas a solos mapeados em nível de reconhecimento com detalhe.

RADAMBRASIL (1983), trabalhando com mosaicos semicontrolados de imagens de radar na escala 1:250.000 e as respectivas faixas estereoscópicas, delimitam e identificam, a nível exploratório - na escala 1:1.000.000 - os solos localizados na região Sudeste do Brasil, abrangendo todo o Estado do Rio de Janeiro e parte dos Estados de Minas Gerais, Espírito Santo e São Paulo. Identificam e descrevem 28 classes de solos, que, juntamente com suas respectivas variações, são agrupadas ou não, de acordo com a conveniência do levantamento, compreendendo 301 unidades. O mapeamento é elaborado pela Divisão de Pedologia do Projeto RADAMBRASIL e pelo Serviço Nacional de Levantamento e Conservação de Solo - EMBRAPA, por força de convênio, dando sequência ao Levantamento de Recursos Naturais do Brasil. 
De acordo com FAGUNDES (1976), a utilidade dessas imagens para o levantamento dos recursos naturais no Brasil, é devido as diversificadas aplicações que lhes vêm sendo dadas, tanto na correção e atualização de mapas existentes, como na sua complementação, na confirmação ou na contestação dos resultados da interpretação das imagens de radar para preparação de mapas temáticos de distintas naturezas; sem contar com a sua maior potencialidade, demonstrada pelo emprego de analisadores multiespectrais, em que, por adição ou subtração de cores, os mais estranhos e expressivos tons, matizes, gamas de contraste e níveis de brilho e saturação, podem ser obtidos, revelando aspectos que a visão humana jamais poderia detectar. 


\section{MATERIAL E MÉTODOS}

\subsection{Material}

\subsubsection{Caracterização do meio físico}

\subsubsection{Localização}

O Parque Estadual da Ilha do Cardoso situa-se entre os paralelos $25^{\circ} 05^{\prime}$ e $25^{\circ} 15^{\prime}$ de latitude sul e os meridianos $47^{\circ} 53^{\prime}$ e $48^{\circ} 06^{\prime}$ de longitude W. Gr., no extremo sul do litoral paulista, com uma área aproximada de 22.500 ha (Figura 1).

\subsubsection{Geologia - geomorfologia}

Segundo PETRI \& FÚLFARO (1970) a extremidade norte da ilha é formada por depósitos arenosos atuais que se estendem da praia do Pereirinha à ponta do Itacuruçá, no lado oriental, numa linha de contato orientada a grosso modo para NNW. Esta parte da ilha possui um relevo baixo sendo grande parte da área inundada durante a preamar normal. No Morro do Pereirinha e na Ponta de Itacuruçá, afloram metarritmitos formando as primeiras elevações que servem de contrafortes às grandes elevações do maciço granítico central. 


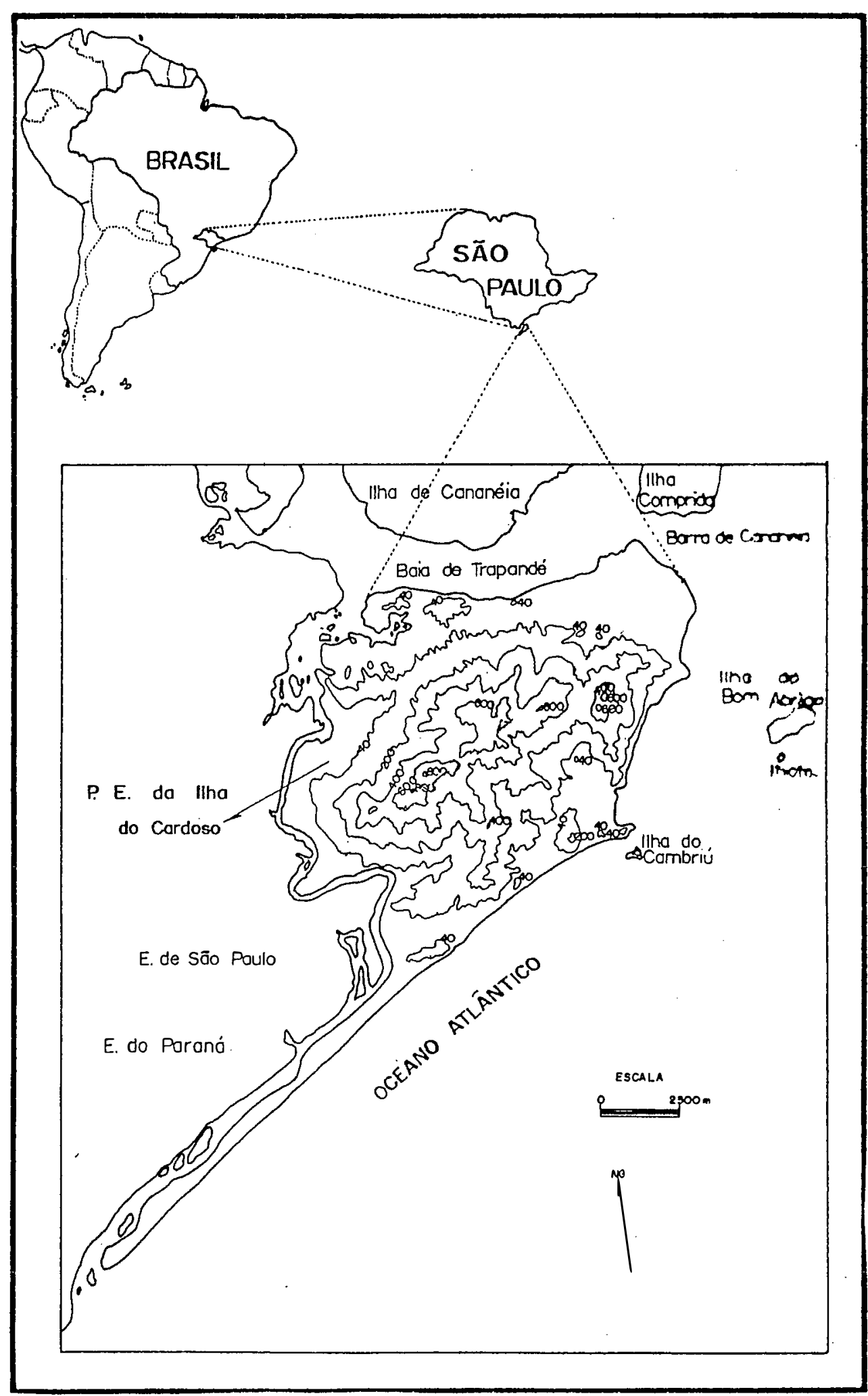

Figura 1 - Mapa de localização do Parque Estadual da Ilha do Cardoso, SP. 
Os metarritmitos consistem em rochas com alternância entre camadas mais grosseiras (areias) e mais finas (siltes). $\mathrm{Na}$ praia do Pereirinha, as estruturas sedimentares associadas a essas rochas são raras e quando presentes sugerem "boudinage". Em leitos individuais mais grosseiros observam-se algumas estruturas como estratificação cruzada e laminação cruzada por migração de marcas onduladas ("ripple-drift cross laminations"). O acamamento ondulado, típico desses depósitos é sugerido mas pode tratar-se de um efeito metamórfico.

Esses metarritmitos não são constantes quanto a espessura apresentandose, leitos e lâminas, em sequência ora mais finas, com alternância mais rápida, ora mais espessas. Em uma dessas sequências de alternância mais rápida (sucessão de lâminas) observa-se uma pequena brecha de contato entre duas lâminas.

A alternância entre as lâminas e leitos de areia e silte, aparentemente, não se dá bruscamente parecendo haver uma passagem gradual entre as duas lâminas básicas dos rítmos.

Ainda no lado ocidental da ilha, descendo-se para o sul, pelo canal de maré que a separa do continente, encontra-se outro afloramento dessas mesmas rochas na ilha da Casca. A altitude dos estratos é a mesma do afloramento e, supondo-se que não haja perturbação tectônica entre os dois pontos, a espessura dessa sequência seria de $5.000 \mathrm{~m}$.

Na parte oriental da ilha encontram-se afloramentos da mesma rocha na praia do Itacuruçá. Aflora uma sequência rítmica de cor avermelhada, com alternância 
entre lâminas de metarenito fino e metassiltito argiloso. Laminação cruzada por migração de marcas onduladas, estratificações cruzadas, escavações e preenchimentos e acamamento ondulado.

No lado meridional da ponta do Itacuruçá, na praia de Ipanema e próximo ao morro do Campestre, aflora um quartzito que está estratigráficamente abaixo dos metarritmitos do lado setentrional do Itacuruçá. Comparando a sequência exposta no lado ocidental da ilha, sua presumida espessura, com a pequena área exposta no oriente da ilha, pode-se pensar ser este quartzito uma lente dentro da sequência rítmica. Os afloramentos de quartzito ocupam uma estreita faixa na praia de Ipanema e no mar adjacente.

As camadas metassedimentares indicam sedimentação original em águas rasas e podem pertencer às sequências descritas por PETRI \& SUGUIO (1969) para a região de Apiaí-Iporanga. A direção NW dos estratos sugere uma ligação com rochas descritas como "migmatitos" que ocorrem em Cajati e a Serra dos Aleixos na rodovia Régis Bittencourt, situada no limite mais oriental da área descrita por aqueles autores. Esses "migmatitos" consistem em uma alternância de faixas claras e escuras que dão o aspecto de um metarritmito. São rochas pouco estudadas e a ausência de estruturas sedimentares visíveis, torna difícil o seu enquadramento como metarritmitos. Por outro lado, mostram-se muito mais perturbadas tectônicamente do que os afloramentos da ilha do Cardoso. O dobramento, ao sul de Jacupiranga, na mesma rodovia, é bem marcado sendo inclusive visíveis dobras de arrasto com empuxo de NE para SW. 
Seria altamente justificável a complementação do trabalho de PETRI \& SUGUIO (1969) para preencher a lacuna existente entre a área de Iporanga-Eldorado e a de Cananéia. De uma maneira geral confirma-se a escassez de depósitos de águas mais profundas, mesmo nos pontos mais orientais da área, podendo-se estender a essas rochas, no momento, as conclusões dos autores citados sobre o ambiente de sedimentação das rochas que afloram na área situada a montante do rio Ribeira.

Entre o afloramento de quartzito e o morro do Campestre aflora uma rocha granírica que ocupa todo o centro da ilha e na qual, estão esculpidos os terraços marinhos.

O primeiro terraço de abrasão é encontrado antes do morro do Campestre e após extenso depósito de enormes seixos de granito.

Esse primeiro patamar erosivo apresenta um desnível de 6 metros com o nível do mar (maré em início de cheia). A superfície de abrasão mergulha $4,5^{\circ}$ para WNW e a extensão exposta é de $50 \mathrm{~m}$.

Pouco mais adiante, com o mesmo desnível encontra-se um outro terraço apresentando um declive de $12^{\circ}$ para NW. A face voltada para o mar, em ambos os terraços, como é normal nessas feições, é abrupta.

No local denominado Borja, ainda próximo ao morro do Campestre, encontram-se dois níveis de terraços esculpidos no granito. O nível mais baixo situa-se a 0,5 metro acima do mar e o patamar de erosão mais alto está 2 metros mais acima. A superfície de separação entre os dois terraços de abrasão é um plano inclinado também suavizado pela erosão marinha. 
Os planos de cizalhamento do granito parecem desempenhar um importante papel na esculturação dessas feições. Como se sabe as rochas do cristalino não favorecem ao mar a construção de tais terraços de abrasão, que constituem uma feição mais comum em depósitos sedimentares existentes na linha de costa. É certo, no entanto, que o intemperismo tropical dá condições de tal tipo de trabalho em rochas mais resistentes à erosão, como assinala FREITAS (1951). A inclinação da superfície de erosão dos terraços, como pode-se constatar, coincide com a direção e mergulho dos planos das diáclases do granito. Explica-se assim, o alto ângulo de mergulho dessas superfícies bem como a suavidade de suas superfícies, pois o trabalho de erosão marinha é grandemente facilitado pela existência desses planos. Suas inclinações para WNW e NW podem também ser assim explicadas.

Os níveis de terraços de abrasão observados na Ilha do Cardoso situam-se no nível de 7 metros citado por FREITAS (1951, Quadros II e III, p. 28) para o litoral dos Estados de São Paulo e Paraná. A única diferença é que a esse nível há um conjunto de dois terraços de abrasão, com o nível mais baixo podendo ser atribuído a ação das vagas atuais. Na localidade denominada Borja, no entanto, na faixa descoberta pelo repuxo das ondas, nota-se um terraceamento ainda mais baixo.

Um pouco mais ao sul, ainda na parte oriental da ilha, junto ao morro do Campestre e antes da ponta do Cambriu, aflora um depósito de tálus, litificado, com matriz arenosa, as vezes conglomerática. Os seixos, totalmente de granito, são bem arredondados, com $60 \mathrm{~cm}$ em média de tamanho, medido no maior eixo. Os seixos 
maiores atingem 1,5 metro na mesma direção. É óbvio que tal arredondamento é devido mais a uma questão de intemperismo atuando sobre os cantos e arestas dos blocos, do que a um retrabalhamento pelo mar.

Visto em fotografia aérea tal depósito apresenta forma decrescente com as pontas voltadas para o mar. Esta forma pode ser explicada pelo retalhamento marinho do antigo cone de dejeção, visto ser a costa da ilha, nesse local, extremamente abrupta.

A superfície superior desse depósito apresenta-se erodida formando um terraço de abrasão já inteiramente coberto por vegetação rala. A espessura do depósito, medida na face abrupta voltada para o mar é de $5 \mathrm{~m}$. De sua base até o nível atual do mar temos mais $2 \mathrm{~m}$, enquadrando-se esse nível, portanto, na faixa de $7 \mathrm{~m}$ referida anteriormente. É imenso, no entanto, o significado geológico deste último afloramento. O terraço de abrasão ("wave cut bench") sempre representa uma superfície de entalhe e uma oscilação do nível do mar ou da terra. Passam, em direção ao mar, a terraços de construção marinha ("wave built terrace"), formados com os sedimentos erodidos das falésias (BLOOM, 1970). Ainda segundo o mesmo autor (idem, p. 143) a energia das ondas tende a diminuir com o tempo, concomitantemente com o alargamento da costa. Deve-se considerar que a evolução de uma paisagem litorânea é horizontal em virtude das costas serem bidimensionais e não vertical como nas paisagens tridimensionais subaéreas. 
O fato de existirem vários níveis de terraços de abrasão, portanto, revela uma oscilação de nível quer do mar quer da terra. Os terraços de abrasão da Ilha do Cardoso revelam características tectônicas da costa local, que merecem atenção.

O tectonismo na área é bastante evidente. Como largo traço tectônico julga-se conveniente ressaltar a posição da baía de Trapandé, entre as Ilhas do Cardoso, Comprida e de Cananéia. Essa baía, orientada no sentido E-W, se interpõe através de sua barra de comunicação com o mar entre as Ilhas do Cardoso e Comprida. Na Ilha Comprida, na parte adjacente a barra, o relevo é baixo, com predominância de depósitos arenosos. Somente defronte a cidade de Cananéia aflora uma rocha alcalina em visível conexão com uma elevação da própria Ilha de Cananéia, constituída por rochas da mesma composição. O embasamento cristalino nessa ponta sul da Ilha Comprida, não aflora e a situação permanece aproximadamente a mesma até a parte média da ilha, onde, em uma sondagem realizada pelo IGG, o cristalino não foi atingido mesmo após a perfuração de mais de uma centena de metros.

Na Ilha do Cardoso, no lado sul da barra acima mencionada, encontram-se os primeiros afloramentos de metarritmitos do embasamento cristalino na praia do Pereirinha, local não muito distante da extremidade sul da Ilha Comprida. Nesse ponto começam as elevações que vão ocupar toda a parte central da ilha. Mesmo sem reconhecer a exata posição das rochas que compõe o embasamento cristalino na ponta sul da Ilha Comprida, os afloramentos ao nível do mar, tanto nessa ilha como na do Cardoso, já indicam claramente uma movimentação relativa ao rebaixamento do 
embasamento da parte sul da Ilha Comprida. Essa direção coincide com o traçado da baía de Trapandé que se considera como ocupando uma linha tectônica.

Os terraços marinhos elevados constituem forte evidência de costa em emergência. Associados a essas feições encontram-se também, nesses casos, sedimentos marinhos situados acima do nível do mar e outras estruturas associadas. Os terraços de abrasão da Ilha do Cardoso, com seu sistema escalonado, demonstram claramente uma costa em emersão. Os escalonamentos, ou seja, níveis de patamares abrasivos distanciados de poucos metros entre si na vertical, indicam que o processo de emergência pode estar se realizando por pulsações, com aparentes fases curtas de equilíbrio entre os estádios de levantamento.

O terraço de abrasão talhado no depósito de tálus do morro do Campestre fornece parte da história tectônica da área. Para a formação desse depósito deve-se pensar na existência de uma fase prévia da região em que a linha de costa se encontrava mais distanciada do que atualmente. Estava, portanto, essa faixa do litoral paulista, mais elevada em relação ao nível do mar. Para que esse depósito tenha sido cortado pela erosão marinha deve-se admitir ainda uma fase de equilibrio suficiente, para que houvesse a litificação do depósito. Evidentemente segue-se a esse estádio um período de submersão com a linha de costa avançando progressivamente em direção à terra. Não se pode precisar nessa fase qual a porção que se movimentou em relação a outra, ou seja, se o nível do mar subiu ou se a terra abaixou. A maior parte dos autores, entre os quais FREITAS (1951), acreditam em uma fase de submersão mundial após a última 
glaciação quaternária, provocada pelo levantamento do nível do mar pelas águas de degêlo. Segundo BLOOM (1970) este levantamento teria ocorrido entre 15.000 e 20.000 anos atrás. A esta fase poderia-se associar o entalhamento do depósito de tálus. A esta submergência da costa, seguiu-se o período de emersão atual.

PETRI \& SUGUIO (1970) descrevem um depósito de areias marinhas regressivas no litoral sul paulista, conhecidas localmente por "piçarras", que ocorrem na forma de lençóis arenosos ("blanket sandstone"). Esses depósitos, que atestam uma antiga submersão dessa faixa litorânea, encontram-se agora elevados em relação ao nível do mar, tendo inclusive sido alvo de retrabalhamento no vale Ribeira, apresentando-se como terraços fluviais. Encontra-se assim o binômio principal de caracterização de uma costa em processo de emersão, os terraços marinhos e praias levantadas. A essa submersão provavelmente corresponde a época dos entalhamentos anteriores do nível de 7 metros.

A movimentação tectônica das costas brasileiras tem sido acusada por vários autores, e uma coletânea dessas informações encontra-se em FREITAS (1951). ALMEIDA (1969) distingue três estádios na diferenciação tectônica da plataforma brasileira sendo a última de reativação. Nesse estádio de reativação tectônica, distingue o mesmo autor, três fases: a primeira do Jurássico ao Cretáceo inferior (pré-Aptiano), a segunda, entre o Aptiano e o Eoceno, e a terceira, entre o Eoceno e o Quaternário. Nesta última tem-se a tendência ao soerguimento epirogênico que vem causando extensa sedimentação continental nas áreas que permanecem baixas. 
MEUNIER \& TALTASSE (1958) descrevem movimentação tectônica nos tabuleiros de Monte Alegre o Rio Tinto a o norte de João Pessoa, na Paraíba, indicando oscilações que seriam adaptações a solicitações tectônicas.

No litoral norte paulista os autores também examinam depósitos de praias levantadas, como os da praia Vermelha, em Ubatuba. Acima da atual praia de Tombo, encontra-se, a 4 metros do nível atual do mar, uma outra superfície de praia já em processo de litificação. Uma crosta com cimento calcífero de $1 \mathrm{~cm}$ de espessura recobre esses depósitos.

Com esses exemplos demonstra-se que o fenômeno de emergência da costa não é restrito a uma dada porção da mesma, mas ocorre em uma amplitude considerável ao longo da costa brasileira. Por outro lado, como vários trechos da costa brasileira têm sido descritos como de submersão (FREITAS, 1951), tem-se que concordar com a classificação do mesmo autor (p. 43) de um tipo composto para a morfologia da costa brasileira. A ascensão da costa do litoral sul paulista prossegue, como o demonstram as estruturas descritas, alvo que são de um movimento epirogênico ascendente. A idade desses fenômenos é provavelmente quaternária.

Com auxílio de fotografias aéreas e bases cartográficas, PFEIFER \& DOMINGUES (1983/85) executaram a fotointerpretação geomorfológica e pedológica aliadas ao controle de campo, elaborando um mapa interpretativo (Figura 2), no qual caracterizaram a geomorfologia e as formações superficiais da Ilha do Cardoso. 


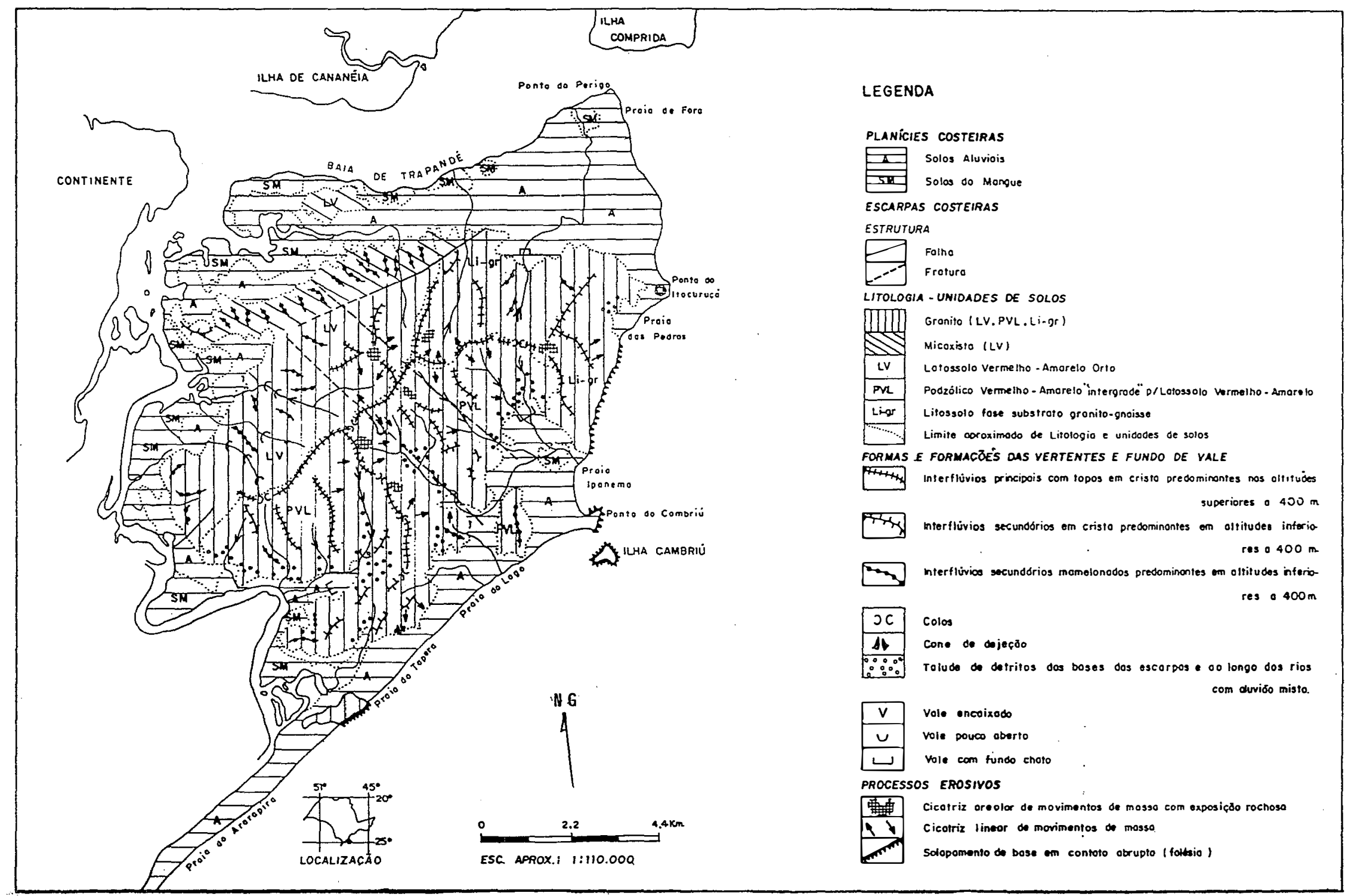

Figura 2. Características geomorfológicas e as formações superficiais do P.E. da Ilha do Cardoso, SP. Fonte: PFEIFER \& DOMINGUES (1.983/85). 
O exame dessa figura sugere que o padrão de drenagem resulta do trabalho das águas, refletindo a presença de um controle litológico/estrutural.

Nos compartimentos topomorfológicos inferiores, ocorrem as planícies costeiras com altitudes de 0-40 m, com baixa densidade de drenagem, padrão meândrico e anastomosado. A morfologia é associada à deposição fluvial, marinha, flúvio-marinha e lagunar, constituída por terraços, bancos arenosos e cordões litorâneos, compondo solos aluviais e os sedimentos vasosos do mangue.

A porção quase absoluta da ilha, é composta por escarpas festonadas costeiras, com nítidos controles estruturais. A morfologia é associada às características geoestruturais, litológicos, pedológicas e aos processos geomorfológicos erosivos e deposicionais como observaram DOMINGUES (1983) e PFEIFER (1984).

No extremo NW, sobre o micaxisto, predominam os interflúvios mamelonados, em altitudes inferiores a $200 \mathrm{~m}$, localmente. $\grave{A} \mathrm{~W}-\mathrm{SW}$ da ilha, ocorre o mesmo em substrato granítico, onde detecta-se predominância do mesmo conjunto de interflúvios, mas em altitudes entre 200 e 400 m.

SUDELPA (1975) observa que, excetuando o pequeno setor de ocorrência de micaxisto, a área compreende um maciço granítico onde ocorrem, predominantemente, espigões com topos em crista (Figura 3).

A estrutura, delineada pelos dobramentos, possibilita aos processos de retrabalhamento da superfície, o encaixe da drenagem em vales profundos e a ocorrência de paredões rochosos em áreas de topos em cristas e vertentes retilíneas, 


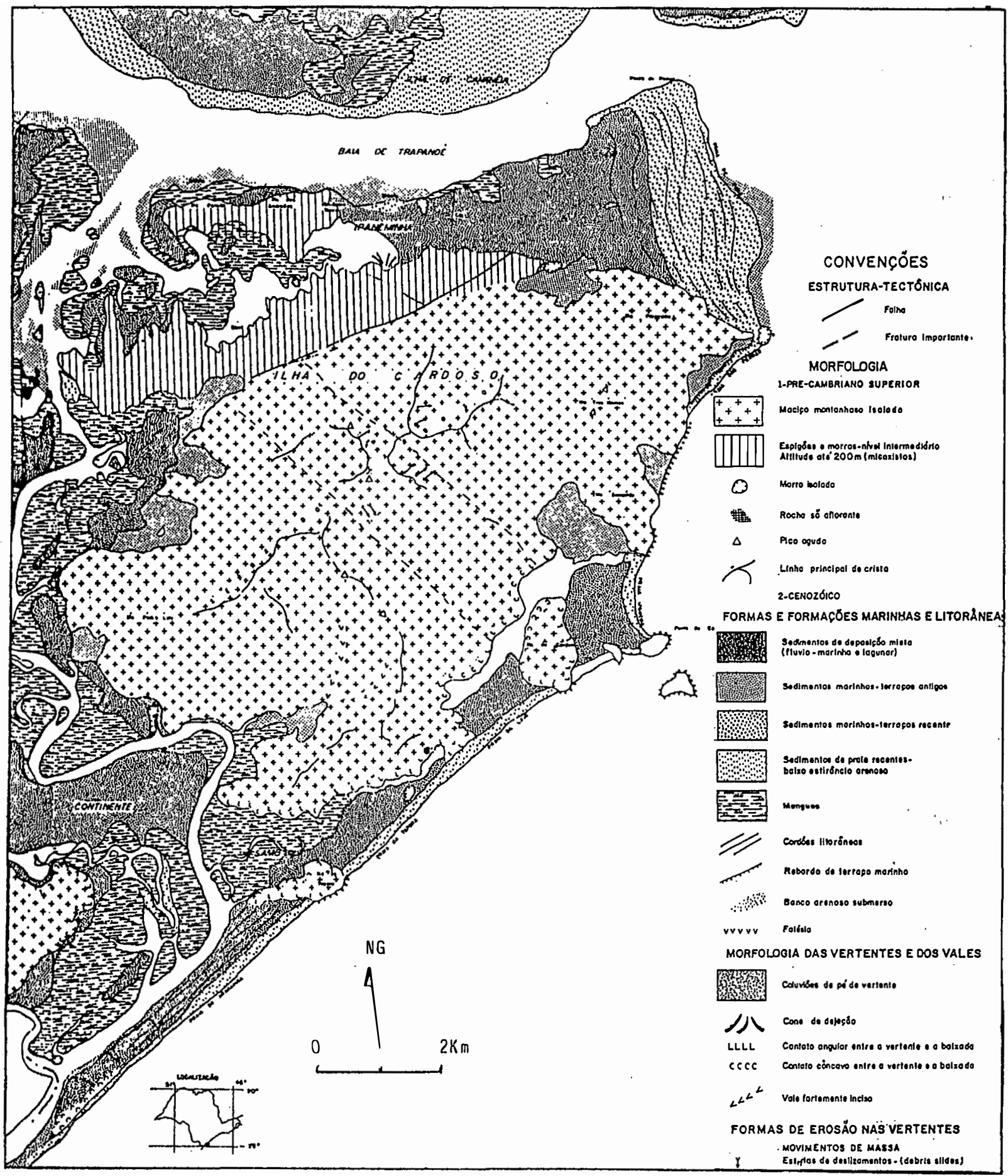

Figura 3 - Mapa geomorfológico.

Fonte: SUDELPA (1975). 
onde ocorrem os solos podzólicos e os litólicos, bem como os movimentos de massas lineares e areolares. As cicatrizes lineares quase sempre expõem a rocha e o solo, enquanto que as aerolares formam extensos paredões rochosos.

A jusante de $400 \mathrm{~m}$, ocorrem alguns interflúvios mamelonados, mas predominam os secundários em cristas. Nos compartimentos de vertentes e fundo de vales, a jusante de $200 \mathrm{~m}$, há predominância dos taludes de detritos, conforme DOMINGUES (1983) também registrou na Serra de Cubatão.

As vertentes E mergulham no oceano, em contato abrupto, dando origem às falésias, permanentemente retrabalhadas pelos processos de solapamentos de base.

Era de se esperar, na ilha, uma ocorrência maior de solos menos desenvolvidos. No entanto, a maior porção de Latossolos e Podzólicos ocorrem em relevo montanhoso, em vários setores, predominando interflúvios íngremes, sugerindo uma interpretação de gênese, associada a o tectonismo, com dobramentos das camadas. Tais características estruturais do embasamento aliadas às condições climáticas, provocam a profunda alteração das rochas e permitem a formação de espessos pacotes de alúvios, que deveriam promover uma acentuada morfogênese devido às altas declividades.

Afora os trechos mais acidentados, a ocorrência dos horizontes B textural e B latossólico, pode ser explicada pela existência de rochas cataclásticas e pelos falhamentos, possibilitando, por intermédio da ação dos processos geomorfológicos, o aparecimento dos interflúvios mamelonados e de formações superficiais mais espessas. 


\subsubsection{Solos}

PFEIFER (1981/82) apresenta o levantamento pedológico semidetalhado do P. E. da Ilha do Cardoso executado a partir da fotointerpretação da rede de drenagem e da interpretação da descrição morfológica dos perfis de solos, localizados em distintos compartimentos do relevo e dos dados analíticos, cujo mapa é apresentado na Figura 4.

A referida carta de solos apresenta 5 unidades de mapeamento cartografadas, algumas delas não levantadas por BRASIL-SNPA (1960), como se seguem:

\section{A. Latossolo Vermelho-Amarelo-Orto $(\mathrm{LV})$}

Esta unidade taxonômica não detectada por BRASIL - SNPA (1960), é constituída de solos argilosos, profundos, de coloração alaranjada, ácidos e com saturação por bases baixa. São solos bem drenados, com B latossólico. Esta unidade de mapeamento ocupa as meias encostas e patamares de morros cristalinos. No sopé e na meia encosta, apresenta relevo forte ondulado e montanhoso. São solos formados a partir de rochas granito-gnaissicas.

Dentre as características morfológicas observadas, destaca-se a ausência de $A_{2}$. Transição gradual entre os sub-horizontes, sendo pouco evidente a diferenciação de horizontes. Horizonte B com grau de consistência macio a ligeiramente duro quando 


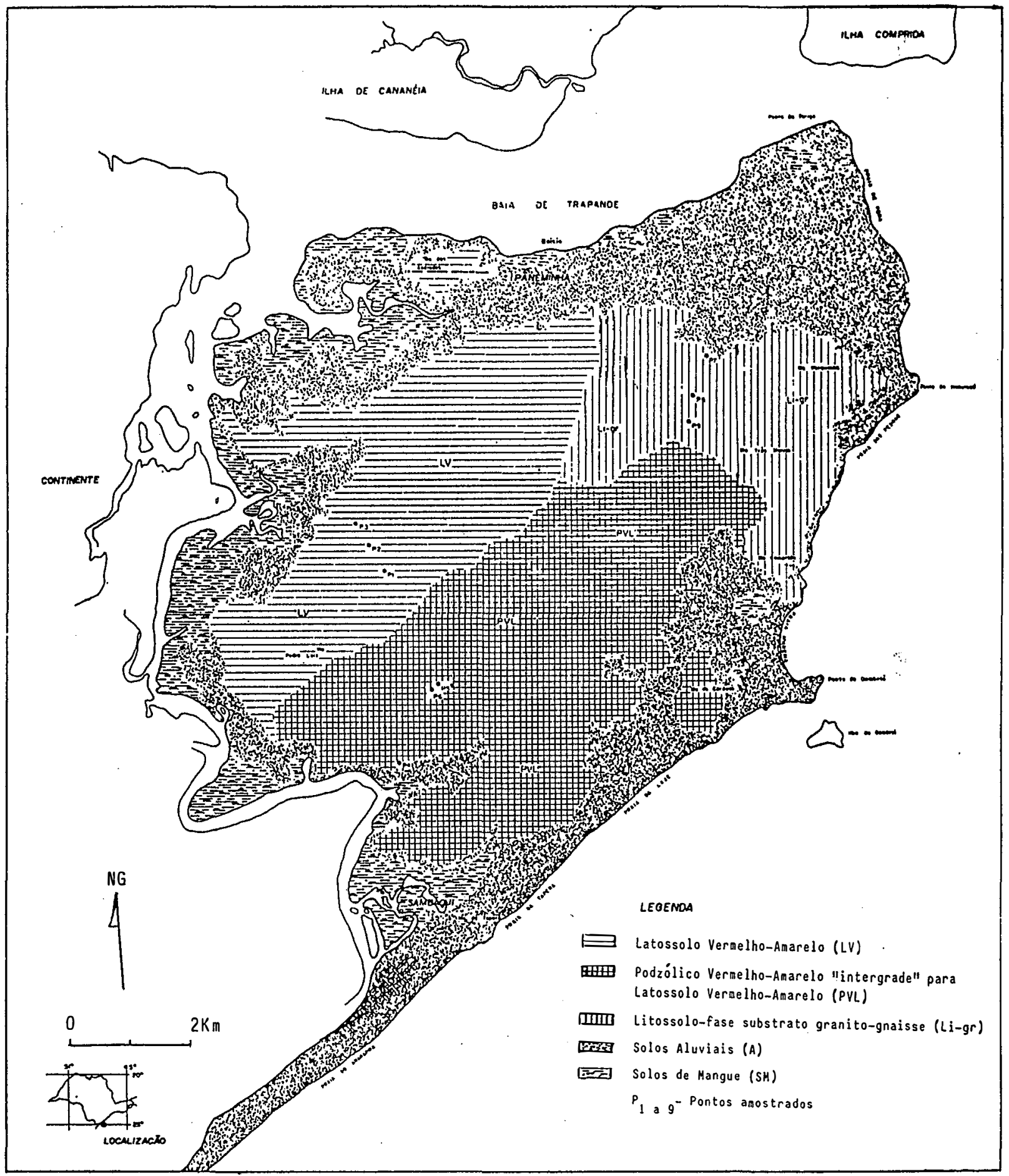

Figura 4 - Carta pedológica.

Fonte: PFEIFER (1981/82). 
seco, friável a muito friável quando úmido e ligeiramente plástico e ligeiramente pegajoso a pegajoso quando molhado. Normalmente a cor á mais vermelha que 2,5YR, o valor varia de 3 a 7 e a croma de 3 a mais elevado. Quando à classe textural, há predominância da "argila", podendo também ser "barro-argiloso", "barro argiloarenoso" e talvez "argilo-arenoso"; a fração argila sempre maior que $15 \%$, podendo o horizonte B ter a mesma quantidade de argila que A ou conteúdo mais elevado. Quando a textura é "argila arenosa" ou "barro-argiloso", a estrutura é muito pequena granular ou pequena granular, apresentando-se também em blocos angulares e subangulares, fraco a moderadamente desenvolvidos. A presença da cerosidade é explicada pela estrutura em blocos. Ausência de mosqueados nos horizontes A e B, mas observados em C, devido à decomposição do material de origem, comprovando BRASIL - SNPA (1960), que caracteriza esta unidade em outras áreas do Estado de São Paulo.

\section{B. Solo Podzólico Vermelho-Amarelo "intergrade" para Latossolo Vermelho} Amarelo (PVL)

Esta unidade é constituída por solos que apresentam características morfológicas mais comuns no Podzólico Vermelho-Amarelo-Orto (PV), destacando-se o horizonte B textural com estrutura em blocos subangulares, presença de filmes de material coloidal (cerosidade) nas superfícies dos elementos estruturais. 
Diferenciam-se do Solo Podzólico Vermelho-Amarelo (PV), por apresentarem as seguintes características morfológicas: melhor drenagem; contraste entre horizonte A e B menos nítido; cerosidade fraca nos horizontes B e mosqueados menos intensos. A textura pode ser "argila", "argilo-arenoso", "barro argiloso", "barroargilo-arenoso" ou "barro- arenoso-grosso". Se a classe textural for "argila" ou "argiloarenoso", o grau de consistência do solo seco é duro; quando úmido firme e quando molhado ligeiramente plástico a plástico e pegajoso. Quando a textura é "barro argiloarenoso", o grau de consistência quando úmido é friável, comprovando as afirmações de BRASIL - SNPA (1960).

\section{Litossolo - fase substrato granito-gnaisse ( $\mathrm{Li}$-gr)}

Esta unidade de mapeamento também não foi detectada por BRASILSNPA (1960).

Apresentam como principal característica a pequena espessura do "solum", a qual em geral é em torno de $40 \mathrm{~cm}$ e sequência de horizontes $A_{1}-R$ sendo que a rocha subjacente, em geral, apresenta-se alterada.

De um modo geral, a classe textural do horizonte A é "barro argiloarenoso" e a estrutura, granular média moderadamente desenvolvida. O grau de consistência é friável para o solo úmido e ligeiramente pegajoso quando molhado. São barrentos com apreciáveis teores de areia. Dentre as bases permutáveis predomina o cálcio, seguido do magnésio e potássio. 
Estes solos ocupam as partes mais acidentadas da área, apresentando-se num relevo montanhoso, com várias exposições rochosas e resultam do entalhamento posterior da superfície mais antiga dos solos B latossólicos, comprovando as observações de Espíndola \& Galhego, citados por CARVALHO (1981).

\section{Solos Aluviais (A)}

Os Solos Aluviais são provenientes de material não consolidado, de deposição recente, apresentando-se em camadas estratificadas, sem relação genética entre si (BRASIL-SNPA, 1960).

Normalmente são profundos, com características morfológicas variando muito ao longo do perfil, de acordo com a natureza do material sedimentar que o formou. Portanto, os perfis podem apresentar camadas sobrepostas de textura similar, ou camadas argilosas sobrepostas a camadas arenosas e vice-versa, fato importante no tocante à drenagem.

Esta unidade normalmente apresenta-se com coloração clara e em áreas cujo relevo é plano ou quase plano e declives bem suaves. De um modo geral, sempre ocupam as cotas mais baixas da região, situando-se nas planícies e fundos de vales formando os terraços dos rios.

Quanto ao material de origem, os solos aluviais provêm de material não consolidado, de deposições recentes, referentes ao quaternário (PETRI \& FÚLFARO, 
1970), sendo constituídos de sedimentos aluviais que formam camadas estratificadas compostas de materiais argilosos, arenosos ou siltosos, dispostos uns sobre os outros, não havendo sequência preferencial na superposição.

\section{E. Solos de Mangue (SM)}

Estes solos mapeados a um nível taxonômico elevado, recebem a denominação genérica de Solos de Mangue, devido à pequena expressão espacial apresentada na área do Parque e ainda pela dificuldade de acesso.

Esta unidade é constituída por solos de várzea, normalmente com relevo plano, pouco profundos, apresentando características associadas com encharcamento, redundando em acumulação de matéria orgânica na primeira camada ou fenômeno de redução nas camadas subjacentes (BRASIL-SNPA, 1960).

Desenvolvem-se a partir de sedimentos aluviais provenientes da decomposição das rochas, ransportados e depositados. Em sua maioria, estes sedimentos são de origem fluvial e marinha.

Possuem relevo plano a suavemente ondulado, sendo sua formação estreitamente relacionada com a topografia.

A dificuldade de penetração nas áreas desta unidade de mapeamento, está condicionada aos encharcamentos e inundações devido à influência do lençol freático elevado e má drenagem. 


\subsubsection{Clima}

Com os dados meteorológicos da base de Cananéia, referentes ao período de 1943-1965, fornecidos pelo $7^{\circ}$ Distrito do INEMET (Inst. Nac. de Meteorologia Ministério da Agricultura), PFEIFER (1981/82) confeccionou o balanço hídrico mensal.

Considerando-se que grande parte do excedente hídrico alimenta o deflúvio ou escoamento superficial, proporcionando o desgaste e consequente transporte de material de uma região para outra, reveste-se a importância da interpretação dos dados meteorológicos.

Segundo a classificação de KÖPPEN, a região apresenta tipo Cfa, clima do tipo mesotérmico úmido, sem estação seca. A alta pluviosidade, aliada a um grau de umidade elevada, dá lugar a uma vegetação exuberante, tipo mata tropical Atlântica, a uma densa rede hidrográfica e uma acentuada evolução dos solos.

A Tabela 1 mostra as variações meteorológicas. A temperatura média anual é de $20,9^{\circ} \mathrm{C}$, sendo que a média das temperaturas máximas é aproximadamente $25,5^{\circ} \mathrm{C}$ e das mínimas $17,4^{\circ} \mathrm{C}$. A temperatura máxima absoluta alcança $32,4^{\circ} \mathrm{C}$ e a mínima absoluta $13,0^{\circ} \mathrm{C}$.

O Balanço Hídrico segundo THORNTHWAITE \& MATHER (1955), Tabela 2 e Figura 5, mostra que a evapotranspiração não acarreta problemas, visto ser esta sempre inferior à pluviosidade. $\mathrm{O}$ total anual atinge $1.051 \mathrm{~mm}$, enquanto que a precipitação é de $2.342 \mathrm{~mm}$, o que dá um saldo livre de $1.291 \mathrm{~mm}$. 


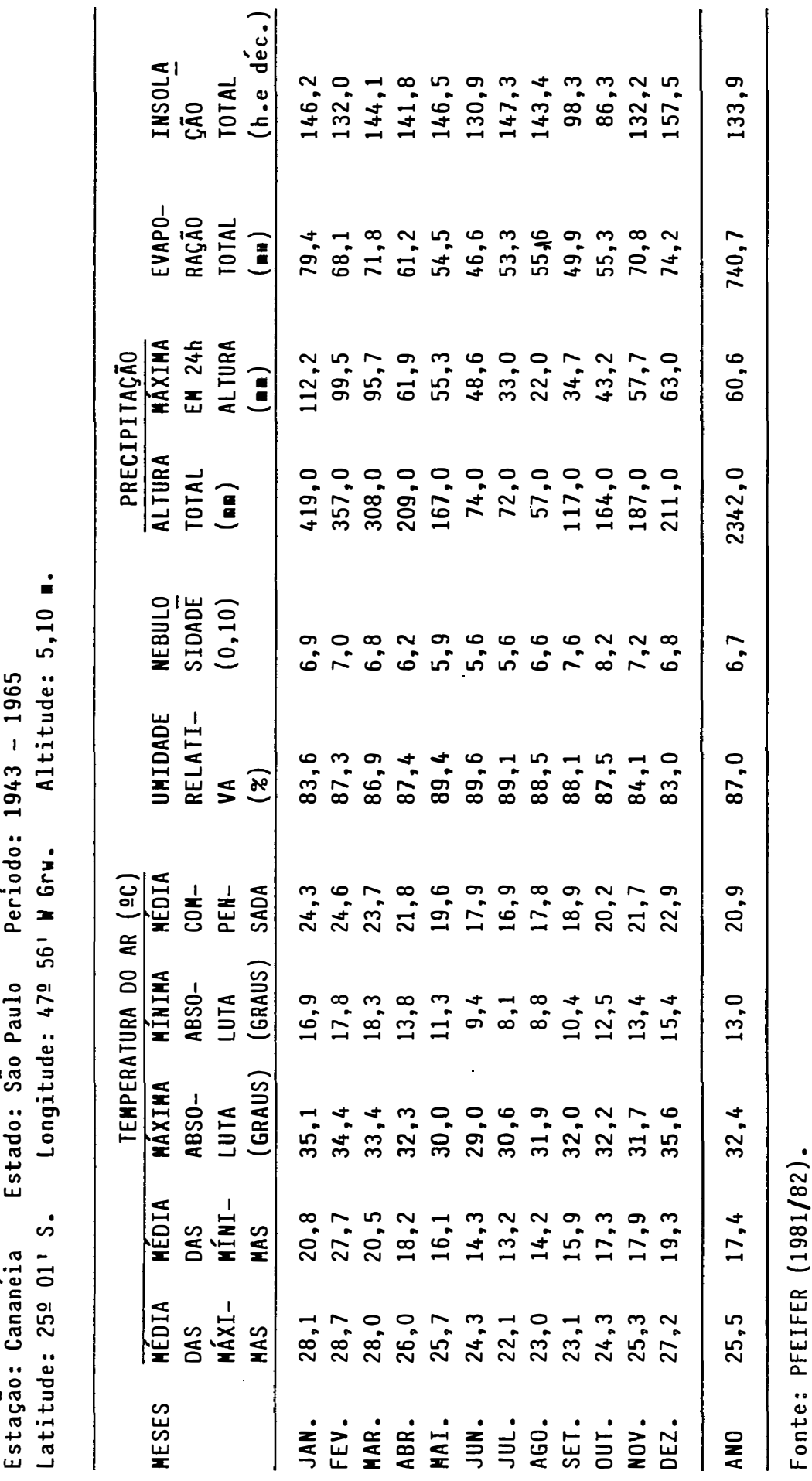


Tabela 2 - Balanço hídrico segundo THORNTHWAITE \& MATHER, 1955.

Local: Cananéia Fonte: 70 Distrito (INEMET) Período: $1943-1965$

Latitude: 250 01'S. Longitude: 470 56' $\mathrm{Grw}$, Altitude: 5,10 $\mathrm{m}$,

\begin{tabular}{|c|c|c|c|c|c|c|c|c|c|c|c|c|}
\hline MESES & $\begin{array}{l}\text { TEMP. } \\
\text { oc }\end{array}$ & $\begin{array}{l}\text { NORHO } \\
\text { GRAH. }\end{array}$ & COR. & $\begin{array}{l}E P \\
m m\end{array}$ & $\begin{array}{l}P \\
m n\end{array}$ & $\begin{array}{l}P-E P \\
m\end{array}$ & $\begin{array}{l}\text { NEG. } \\
\text { ACUM }\end{array}$ & $\begin{array}{l}\text { ARH. } \\
\text { an }\end{array}$ & $\begin{array}{l}\text { ALT. } \\
m \infty\end{array}$ & $\begin{array}{l}E R \\
\mathbb{M} \mathbb{R}\end{array}$ & $\begin{array}{l}\text { DEF. } \\
\end{array}$ & EXC. \\
\hline JAN. & 24,3 & 3,9 & 35,1 & 137 & 419 & 282 & 0,0 & 300 & 0,0 & 137 & 0,0 & 282 \\
\hline FEV, & 24,6 & 4,0 & 30,3 & 121 & 357 & 236 & 0,0 & 300 & 0,0 & 121 & 0,0 & 236 \\
\hline MAR. & 23,7 & 3,9 & 31,5 & 123 & 308 & 185 & 0,0 & 300 & 0,0 & 123 & 0,0 & 185 \\
\hline ABR. & 21,8 & 3,0 & 28,8 & 86 & 209 & 123 & 0,0 & 300 & 0,0 & 86 & 0,0 & 123 \\
\hline MAI。 & 19,6 & 2,3 & 28,2 & 65 & 167 & 102 & 0,0 & 300 & 0,0 & 65 & 0,0 & 102 \\
\hline JUN. & 17,9 & $1,9^{\circ}$ & 26,4 & 50 & 74 & 24 & 0,0 & 300 & 0,0 & 50 & 0,0 & 24 \\
\hline JUL., & 16,9 & 1,7 & 27,9 & 47 & 72 & 25 & 0,0 & 300 & 0,0 & 47 & 0,0 & 25 \\
\hline AGO. & 17,8 & 1,9 & 29,4 & 56 & 57 & 1 & 0,0 & 300 & 0,0 & 56 & 0,0 & 1 \\
\hline SET. & 18,9 & 2,1 & 30,0 & 63 & 117 & 54 & 0,0 & 300 & 0,0 & 63 & 0,0 & 54 \\
\hline OUT. & 20,2 & 2,3 & 33,0 & 76 & 164 & 88 & 0,0 & 300 & 0,0 & 76 & 0,0 & 88 \\
\hline NOV. & 21,7 & 3,0 & 33,3 & 100 & 187 & 87 & 0,0 & 300 & 0,0 & 100 & 0,0 & 87 \\
\hline DEZ. & 22,9 & 3,6 & 35,4 & 127 & 211 & 84 & 0,0 & 300 & 0,0 & 127 & 0,0 & 84 \\
\hline ANO & 20,9 & - & - & 1051 & 2342 & 1291 & 0,0 & - & 0,0 & 1051 & 0,0 & 1291 \\
\hline
\end{tabular}

Fonte: PFEIFER (1981/82)。 


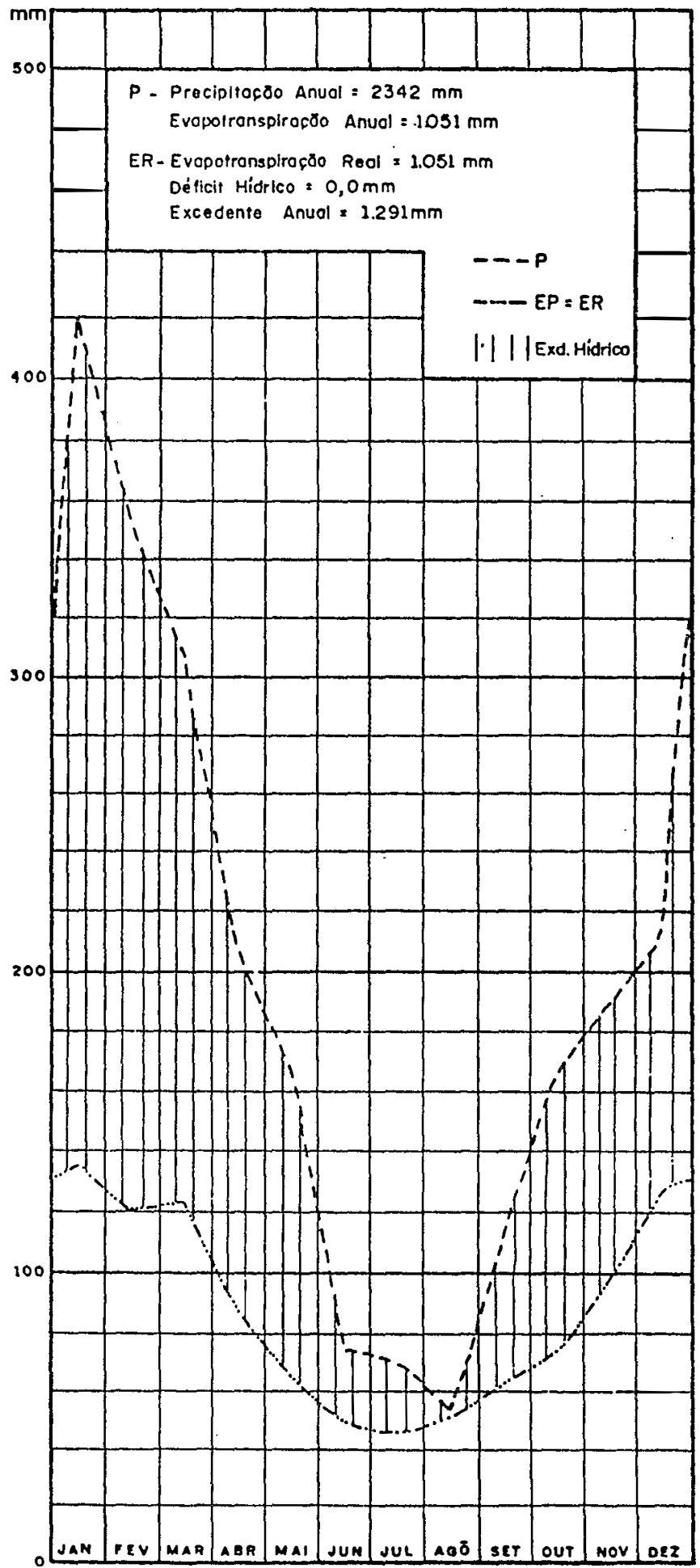

Figura 5 - Gráfico do balanço hídrico.

Fonte: PFEIFER (1981/82). 


\subsubsection{Vegetação}

As formações vegetais Pioneira de Dunas, Restinga, Mangue, Floresta Pluvial Tropical de Planície Litorânea e Floresta Pluvial Tropical da Serra do Mar são identificadas e mapeadas por NOFFS \& BAPTISTA-NOFFS (1982) no P. E. da Ilha do Cardoso, através do emprego de fotointerpretação, sendo apresentadas na Figura 6.

A vegetação pioneira de dunas encontra-se distribuída na faixa arenosa situada na orla oceânica da planície costeira, constituída por sedimentos de praias recentes, não consolidados. As maiores extensões ocupadas por esta formação ocorrem à nordeste, na praia compreendida entre a Barra de Cananéia e a Ponta de Itacuruçá, e ao sul-sudeste, na praia compreendida entre a Vila de Marujá e a Barra do Ararapira. A dinâmica desse processo de sedimentação e fixação da areia pela vegetação pioneira é mais notável nas porções nordeste e extremo sul.

A vegetação de restinga está distribuída pela planície arenosa, após a vegetação pioneira de dunas, sobre sedimentos marinhos recentes consolidados. As maiores extensões ocupadas por esta formação ocorrem à nordeste e sul-sudeste.

A vegetação de mangue distribui-se na planície litorânea, sobre sedimentos lodosos, nas desembocaduras dos rios e ao longo do canal do Arapira. De forma geral esta formação está situada na face da Ilha do Cardoso voltada para os canais internos, exceção feita ao mangue da foz do rio Cambriú, voltado para a costa atlântica, onde as águas do rio são obstruídas pela presença de um banco arenoso. 


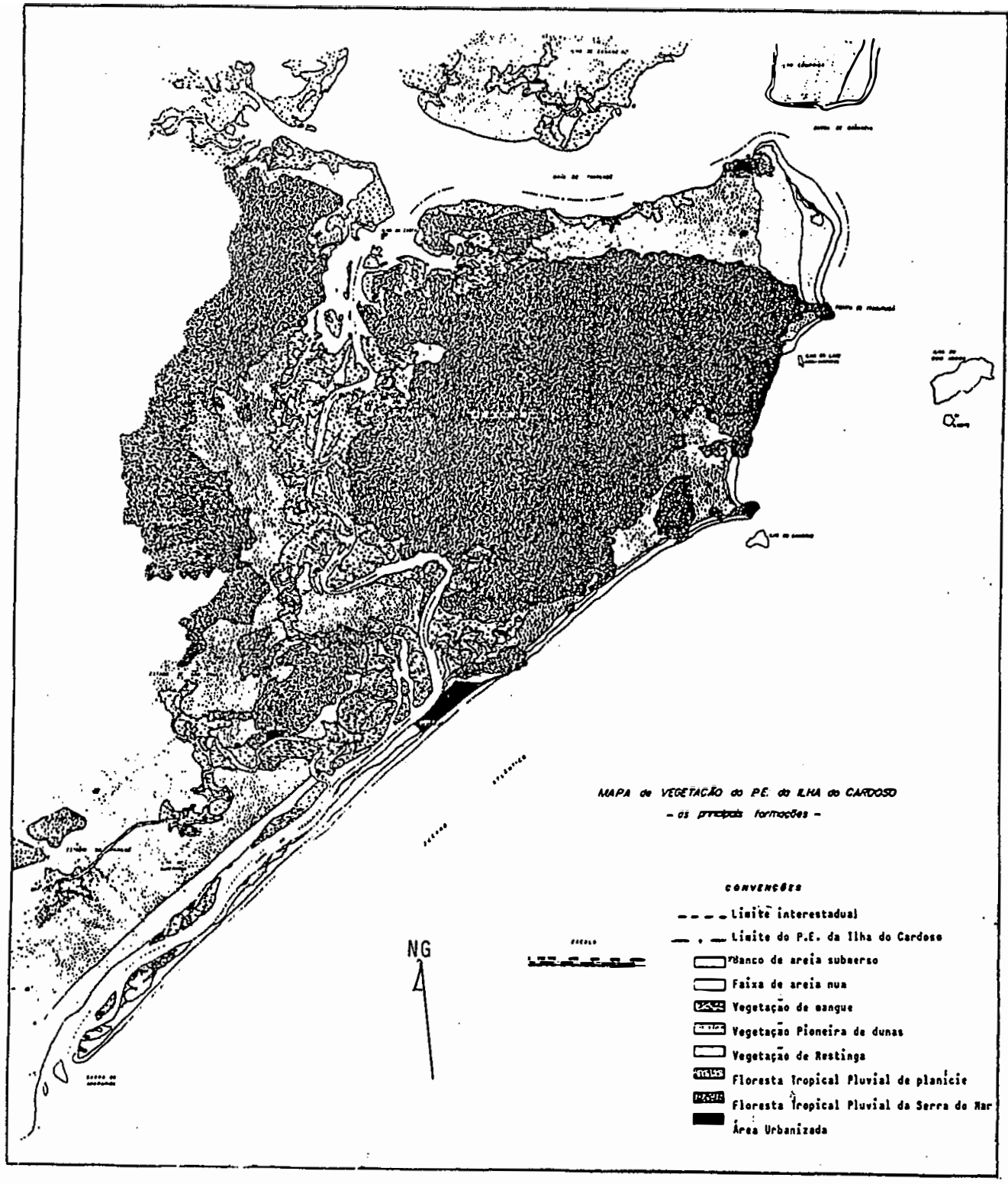

Figura 6 - Mapa da vegetação do P.E. da Ilha do Cardoso - as principais formações. Fonte: NOFFS \& BAPTISTA-NOFFS (1982). 
A floresta pluvial tropical da planície costeira extende-se sobre a planície ocupada por sedimentos arenosos marinhos e flúvio-marinhos antigos, ocupando o perímetro do maciço montanhoso central. As maiores extensões desta formação ocorrem a norte e leste da Ilha do Cardoso.

A floresta pluvial tropical da Serra do Mar encontra-se distribuída pelas encostas do maciço montanhoso Central e dos morros isolados, estando em contato com o oceano no costão rochoso da face leste e apresenta-se como a formação de maior extensão entre as existentes na Ilha do Cardoso.

\subsubsection{Correlação entre características do meio biofísico do Parque Estadual da Ilha do Cardoso}

São apresentadas nas Figuras 7 e 8 as correlações entre as características do meio biofísico estabelecidas por PFEIFER et al. (1989), a partir do corte A - B, desde o canal do Ararapira, no Complexo Lagunar, passando pela porção montanhosa e atingindo a praia no Oceano Atlântico. Os fatores estudados (solos, altitude, declividade, clima, geomorfologia, geologia e vegetação), apresentam-se compartimentados segundo a interceptação do corte A - B, em cada um dos mapas correspondentes. 


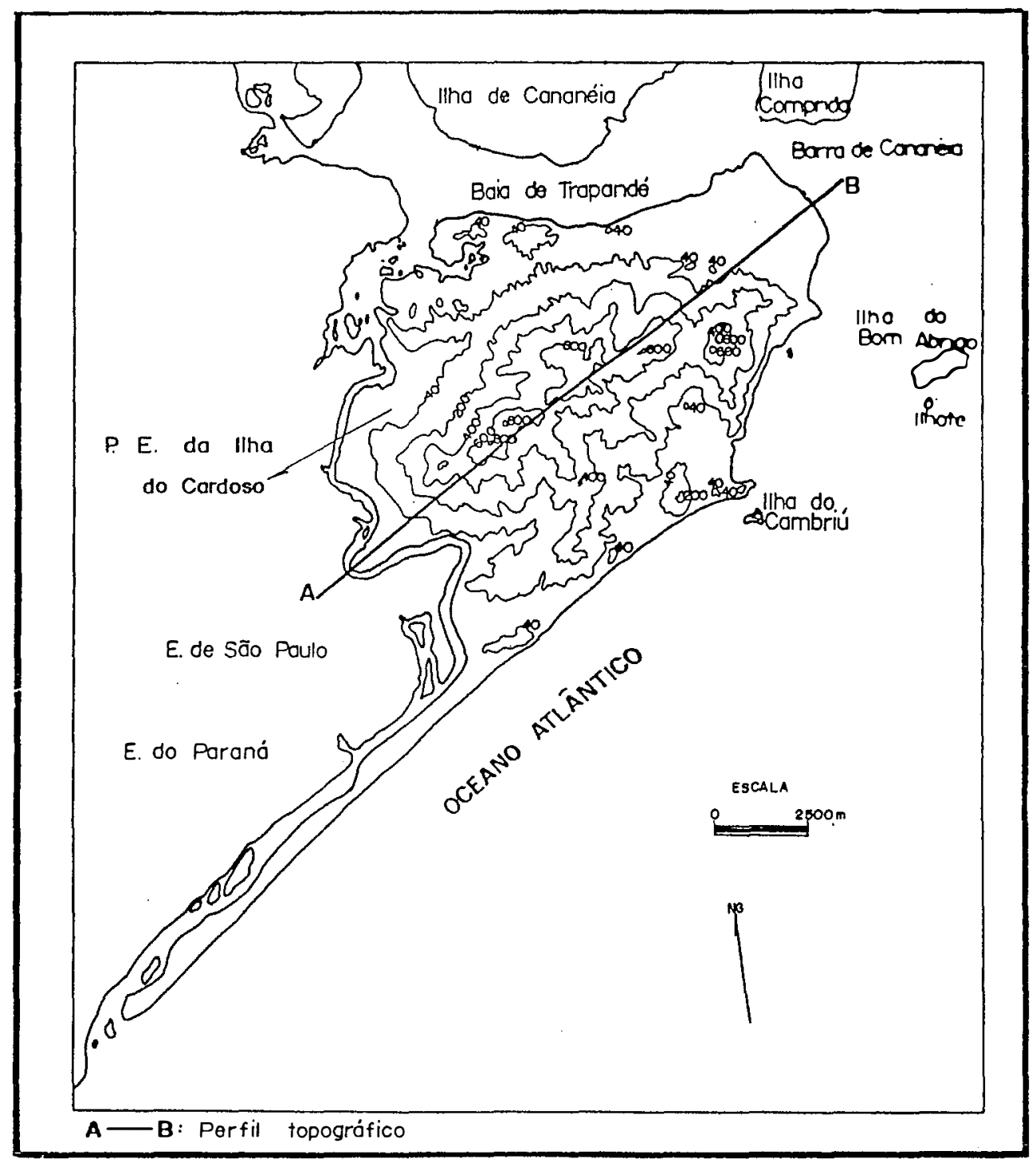

Figura 7 - Mapa de localização do perfil topográfico A - B.

Fonte: PFEIFER et al. (1989). 


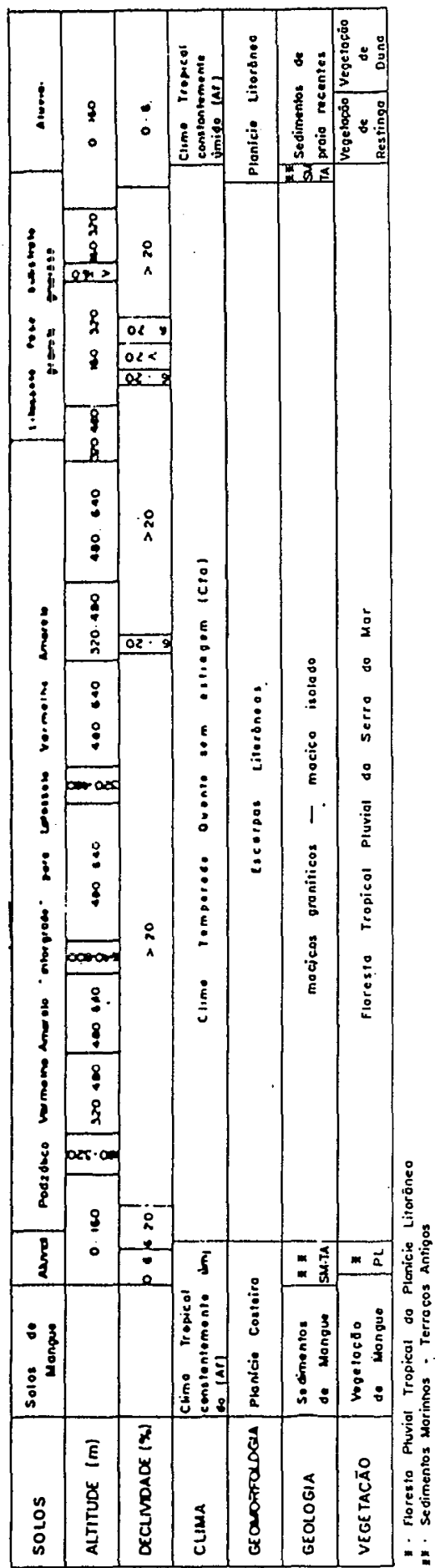

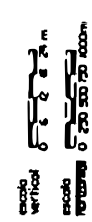

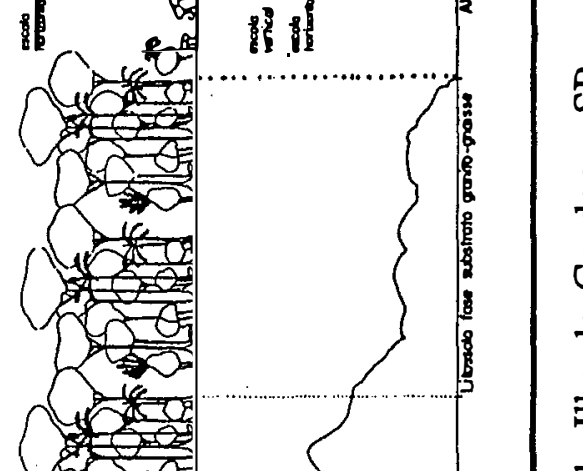

सि
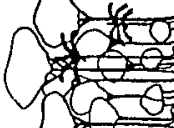

25
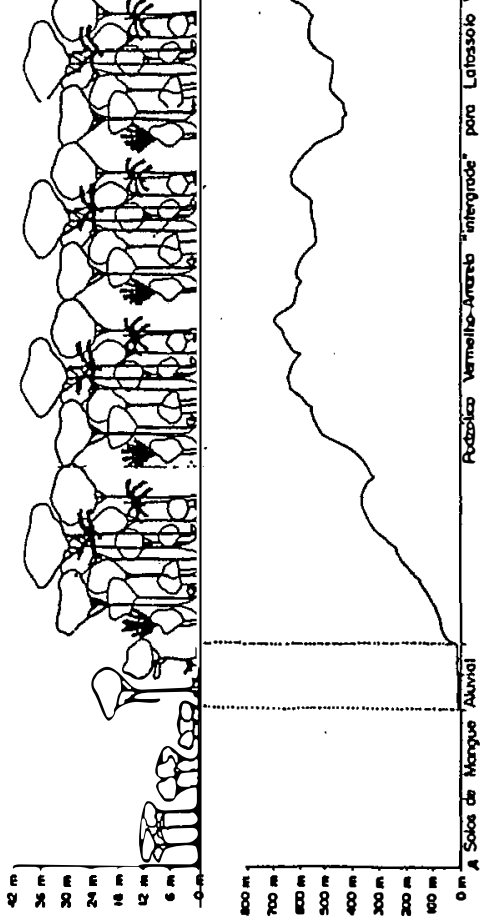

穴

ถิ

군

0

气

ช

(1)

ค

음

을

造

م음

을

음

ช

总

式

ㅎํㅇ

षृ

ஜ สं

侥

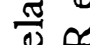

至

U

$\infty \frac{1}{2}$

苟

is 
Assim sendo, a Planície Sedimentar apresenta-se com clima do tipo Af e declividades abaixo de $6 \%$, e:

a) Solos de Mangue que ocorrem encravados em aluviões da planície costeira. No setor compreendido abaixo do nível da maré mais alta, está associado, morfologicamente, a deposição fluvial marinha e lagunar, constituída por sedimentos lodosos, portanto, permanentemente inundados, o que concorda com PFEIFER \& DOMINGUES (1983/85). Apresentam uma aeração dificultada e/ou ausente o que condiciona a vegetação uma especialização em elevados índices de salinidade e uma compartimentação. Em setores de contato com o Solo Aluvial, a vegetação apresenta fisionomia herbácea exposta ao ar e a medida que se distanciam do referido contato, a fisionomia se apresenta, progressivamente, arbórea com pneumatóforos e raízes aéreas, em função da periodicidade da inundação (NOFFS \& BAPTISTA-NOFFS, 1982);

b) Solos Aluviais que se apresentam em camadas estratificadas, sem relação genética entre si. Localizam-se em áreas de relevo plano ou quase plano, com declives suaves e em clima tropical úmido de planície costeira. Morfologicamente estão associados à deposição flúvio-marinha e lagunar, constituídos por bancos arenosos e cordões litorâneos (PFEIFER, 1981/82). Quando voltados para o complexo lagunar, terraços antigos, apresentam a Floresta Tropical Pluvial da Planície Litorânea, com dossel 
arbóreo fechado, sem emergentes, com árvores e palmeiras de pequenos a médios diâmetros (DAP), além de denso sub-bosque, com vegetação herbácea e arbustiva, abundância de bromélias, bambus, epífitas e pseudolianas. Na costa voltada ao Oceano, sobre sedimentos de praia, apresentam uma transição entre a Vegetação Pioneira de Dunas e a Vegetação de Restinga, variando de campo esparso de vegetação herbácea, com caules rastejantes e raízes adventícias, fixando dunas, para vegetação arbórea baixa, com arbustos, distribuída na forma de faixas alternadas com vegetação característica de brejos herbáceos, concordando com as observações de NOFFS \& BAPTISTA-NOFFS (1982) e DE GRANDE \& LOPES (1981).

O Maciço Montanhoso apresenta-se com clima do tipo Cfa e declividades que variam de $6 \%$ a $20 \%$, e:

a) Solo Podzólico Vermelho-Amarelo "intergrade" para Latossolo Vermelho-Amarelo que são formados a partir de rochas graníticas e apresentam estrutura delineada pelos dobramentos que possibilitam aos processos de remabalhamento da superfície, o encaixe da drenagem em vales profundos e a ocorrência de paredões rochosos em áreas de topos íngremes. A alta pluviosidade e umidade relativa do ar possibilitam a existência da densa cobertura vegetal (PFEIFER, 1981/82). Apresentam vegetação arbórea com dossel fechado e emergentes da Floresta Pluvial Tropical da Serra do Mar; árvores e palmeiras de caules com diâmetros variando de médios a grandes e 
sub-bosque ralo com presença de vegetação herbácea arbustiva e arbórea, com presença de lianas, pseudo-lianas e epífitas, além da ocorrência de árvores com expansões caulinares (NOFFS \& BAPTISTA-NOFFS, 1982);

b) Litossolo fase substrato granito-gnaisse que ocorre nas escarpas litorâneas, caracterizado pela diminuição da profundidade do perfil e pela própria posição no relevo, acidentado, com declives variando entre as mais diversas classes. Características que associadas ao tipo de canais fluviais, levam a crer que esta unidade taxonômica está sujeita a um controle estrutural (PFEIFER \& DOMINGUES, 1983/85); podendo ser atribuídas a uma maior influência dos fatores relevo e tempo (MARCOS \& KINJO, 1967). A vegetação arbórea com dossel fechado e emergentes da Floresta Pluvial Tropical da Serra do Mar, apresenta árvores e palmeiras com diâmetros de caules variando de médios a grandes. Nos setores que apresentam declives mais íngremes, a vegetação passa a arbórea, média a baixa, com pequenos diâmetros de caule e sub-bosque ralo, apresentando vegetação herbácea, arbustiva e arbórea. Nos declives menos íngremes, lianas, pseudo-lianas e epífitas, além de árvores com expansões caulinares (NOFFS \& BAPTISTA-NOFFS, 1982).

\subsubsection{Material cartográfico}

$\mathrm{Na}$ execução deste trabalho foram utilizadas as seguintes cartas: 
. carta topográfica do Parque Estadual da Ilha do Cardoso na escala de 1:25.000, com equidistância entre curvas de nível de 40 metros, executada pela Seção de Desenho, Fotografia e Cinematografia do Instituto Florestal (SP), em 1977. Tal planta é extraída e ampliada da base topográfica plani-altimétrica DSG, na escala de 1:50.000, editada em 1971;

- mapa geológico-geomorfológico no 18 , folha SG.22-X-D-III-2-Ariri e mapa $\mathrm{n}^{\mathrm{0}} 19$, folha SG.23-V-C-I-I-Cananéia, do Relatório final geomorfologia, na escala de 1:50.000, do Projeto SUDELPA, Volume XIII; Anexo VIII, Parte I, elaborado em 1975

- mapa das características geomorfológicas e das formações superficiais das escarpas do P. E. da Ilha do Cardoso (SP), na escala de 1:25.000, elaborado por PFEIFER \& DOMINGUES (1983/85);

- carta de solos do P. E. da Ilha do Cardoso (SP), na escala de 1:25.000, elaborado por PFEIFER (1981/82); e

- mapa da vegetação do P. E. da Ilha do Cardoso (SP), na escala de 1:25.000, elaborado por NOFFS \& BAPTISTA-NOFFS (1982). 


\subsubsection{Produtos de sensores remotos}

No presente trabalho empregam-se os seguintes produtos fotográficos:

- fotoíndice na escala aproximada de 1:100.000 para a localização numérica das aerofotografias;

. fotomosaico semicontrolado na escala aproximada de 1:25.000;

. fotografias aéreas pancromáticas e verticais, provenientes da cobertura aerofotogramétrica do Estado de São Paulo, efetuada em 1972, na escala nominal aproximada de 1:25.000;

. imagem orbital obtida a partir do sensor "Thematic Mapper" (TM) instalado a bordo do satélite Landsat-5, sob a forma de cópia em papel, na escala de 1:50.000, composição colorida 3-4-5, correspondente a região do vermelho, infravermelho próximo e infravermelho médio, respectivamente; Revolução 42.855 , base 220 , ponto 77 , quadrante $\mathrm{D}$, sub-quadrante $\mathrm{B}$ e de passagem em 22.03.1992; e

. imagem de radar GEMS 1.000, Folha SG.23-V-C, tipo abertura sintética banda X, vôo 1975/76 do Projeto RADAMBRASIL, na escala 1:250.000, reprodução 1976 do sistema de projeção UTM, mosaico semicontrolado - cópia "off set". 


\subsubsection{Equipamentos}

Para observação estereoscópica dos pares de fotografias aéreas emprega-se um estereoscópio de espelhos marca Wild-ST 4 e um estereoscópio de bolso, marca Vasconcellos.

Para a transferência de detalhes da aerofotografia para o mapa básico, utiliza-se um "aero-skechtmaster" da Zeiss modelo LUZ.

Para facilitar a extração de informações das imagens, utiliza-se uma mesa de luz e as observações realizadas sob lente de aumento com luminária acoplada.

Para as diversas medições utilizam-se equipamentos convencionais de medição e desenho, como escalímetro, curvímetro Derby, compasso de ponta seca e planímetro polar marca OTT.

\subsection{Métodos}

\subsubsection{Seleção e interpretação da área de estudo}

A escolha da área se prende ao fato da mesma possuir carta topográfica, cobertura aerofotogramétrica, imagens de satélite e de radar, levantamento geológicogeomorfológico, carta de solos, tipo climático e mapeamento da vegetação em escalas compatíveis com os propósitos desta pesquisa, o que proporciona maior segurança, 
minimizando o trabalho na fase de correlação entre o produto da interpretação das diversas imagens e a verdade terrestre. Concomitantemente, é interessante a heterogeneidade da área com relação às unidades de solo ocorrentes, permitindo a avaliação do material (aerofotografias, imagens de satélite e de radar) e dos critérios de interpretação em situações diversificadas, bem como uma avaliação da compatibilização das escalas utilizadas.

Assim sendo, a escolha do Parque Estadual da Ilha do Cardoso se justifica, além de ser um dos mais importantes acidentes topográficos do município de Cananéia e detentora de uma das maiores áreas contínuas de florestas primárias preservadas, considerando-se as áreas de matas naturais remanescentes do Estado de São Paulo.

Posteriormente, seguindo o método de pesquisa lógica sugerido por RABBEN (1960), são selecionadas as fotografias aéreas, imagens de satélite e de radar representativas das unidades de solo de interesse dentro dos limites das unidades fisiográficas, para serem analisadas mais detalhadamente.

\subsubsection{Obtenção dos mapas básicos de drenagem}

Através de exame estereoscópico das fotografias aéreas, são traçados sobre papel poliéster estático todos os canais de drenagem bem definidos, quer sejam de cursos d'água perenes ou temporários, conforme sugerem STRAHLER (1957), 
LUEDER (1959) e RAY (1963). Os conjuntos de templetos, contendo o traçado da rede de drenagem para cada unidade de solo, são montados através da utilização da área útil das aerofotografias, para assim, eliminar em grande parte as distorções de escala, que normalmente ocorrem nas bordas das mesmas. Como produto final, obtém-se o mapa básico da rede de drenagem, sobre o qual as áreas homogêneas quanto ao relevo são delimitadas.

Para o caso das imagens orbital (1:50.000) e de radar (1:250.000), inicialmente delimitam-se os elementos da rede de drenagem superficial, traçados em uma folha de acetato transparente, colocada sobre as imagens, reunindo-se as informações obtidas na composição colorida 3-4-5 e no mosaico semicontrolado, respectivamente.

O emprego dessas imagens apresenta certas limitações, impostas pela resolução espectral e pela escala, dificultando o traçado dos canais de ordens inferiores, ou sejam, das cabeceiras de drenagem, principalmente em áreas de maior densidade hidrográfica, conforme atestam vários autores (KOFFLER, 1976a; TOWNSHEND et al., 1979; EPIPHANIO et al., 1983; VALÉRIO FILHO, 1984; COVRE et al., 1986 e VETTORAZZI, 1988). Para tanto, lança-se mão da visão sinóptica da área, possibilitada pelas imagens em escalas pequenas e através da avaliação de relevo e uso da terra (vegetação natural), procurando-se uma melhor aproximação no traçado da rede, por inferências sobre a existência ou não de canais funcionais.

Todos os passos metodológicos que se seguem, referem-se à descrição do trabalho realizado para cada produto de sensor remoto, isto é, para fotografias aéreas 
(1:25.000), imagem de satélite (1:50.000) e imagem de radar (1:250.000), com a finalidade de não torná-los repetitivos.

\subsubsection{Delimitação de áreas homogêneas quanto ao relevo}

Devido à estreita relação entre as características da rede de drenagem e as condições topográficas de uma região, a delimitação das áreas homogêneas quanto ao relevo é traçada sobre os próprios mapas da rede de drenagem.

Conforme sugerido por GOOSEN (1967), essa delimitação é elaborada com base nas mudanças do relevo possíveis de serem detectadas nas imagens.

Além de aspectos da drenagem superficial, a compartimentação do relevo em áreas homogêneas baseia-se também nas variações ocorridas com a textura fotográfica que, em última análise, refletem alterações, entre outras coisas, no uso da terra, na rede de drenagem (ambos fornecendo indicativos sobre as condições topográficas) e no próprio relevo, neste caso através do efeito de sombras, procedimento este comprovado por vários autores, como GIMBARZEVSKY (1974a), WALKER \& TREXLER (1977) e VALÉRIO FILHO (1984).

\subsubsection{Mapeamento das unidades fisiográficas}

Sobre os mapas da rede de drenagem, acrescidos do traçado dos limites indicativos das mudanças no relevo, quando necessário é elaborado uma nova 
compartimentação, desta vez em função de aspectos qualitativos (visuais) da drenagem superficial, isto é, as áreas homogêneas quanto ao relevo são subdivididas em áreas homogêneas também quanto à rede de drenagem. As áreas resultantes são denominadas "unidades fisiográficas", com características que permitem o seu enquadramento na definição de "unidade de mapeamento morfológico" dada por BRINK et al. (1966), ou seja, "uma área com padrão definido de fisionomias do terreno que estão geneticamente relacionadas".

Este procedimento de mapeamento é adotado com base nos fundamentos do método de "análise de elementos" que, segundo GOOSEN (1967), parte do princípio que qualquer elemento da paisagem pode estar relacionado a uma certa unidade de mapeamento de solo e, portanto, uma mudança no elemento pode estar correlacionada com um limite entre solos. Cita ainda que, cada elemento pode ser analisado separadamente e os resultados das análises individuais passíveis de serem combinados, através da superposição de mapas. Como resultado ter-se-á um mapa com um grande número de linhas, nem todas coincidindo com limites entre solos. Trabalhos posteriores de campo é que irão definir as linhas que deverão permanecer e as que serão eliminadas.

As unidades fisiográficas são numeradas e, posteriormente, cada uma delas é analisada e caracterizada em detalhes, com relação aos critérios "relevo" e "rede de drenagem". 
3.2.5. Caracterização das unidades fisiográficas quanto à rede de drenagem e ao relevo

\subsubsection{Rede de drenagem superficial}

As unidades fisiográficas são caracterizadas, quanto ao padrão da rede de drenagem, tanto descritiva quanto quantitativamente.

A) Características descritivas

Adotam-se as características sugeridas por LUEDER (1959), acrescidas do "tipo ou modelo" (PARVIS, 1950).

A.1) Densidade: numa análise descrita a densidade de drenagem indica o número relativo de canais por unidade de área. Segundo MONTEIRO \& SILVA (1979), a análise correta da densidade permite inferências acerca de aspectos do terreno como textura, permeabilidade, porosidade, escoamento superficial, erosão e também condições climáticas. Pode ser classificada em - muito baixa, baixa, média, alta e muito alta.

A.2) Grau de uniformidade: indica a repetição de formas num determinado espaço, ou seja, a homogeneidade relativa dos canais numa determinada área, no caso a unidade 
fisiográfica. De acordo com ROCHA (1986), o grau de uniformidade da rede de drenagem fornece subsídios para assinalar unidades de solos e rochas para os respectivos mapeamentos. O padrão de drenagem pode ser classificado, quanto ao grau de uniformidade em - não uniforme, pouco uniforme e uniforme.

A.3) Ângulos de junção: são os ângulos formados na confluência de um tributário com seu receptor. MONTEIRO \& SILVA (1979) citam que a análise correta desses ângulos fornece evidências de elementos estruturais e indicações do substrato rochoso quanto à sua profundidade relativa. Podem ser classificados, genericamente, em - retos, agudos e obtusos (os agudos podem ser subdivididos em abertos e fechados).

A.4) Orientação: diz respeito a aspectos direcionais, tais como a predominância de direção dos canais. Esta característica, segundo os mesmos autores, fornece indicações sobre os elementos tectônicos (falhas, fraturas e dobramentos) e profundidade relativa do substrato. O padrão de drenagem, quanto à orientação, pode ser classificado em não orientado, pouco orientado e orientado.

A.5) Angularidade: refere-se à mudança brusca de direção dos canais em vales encaixados. Pode indicar, de acordo com os autores supracitados, a influência de fatores estruturais, como por exemplo falhas, a existência e localização do material rochoso. Pode ser classificada em - baixa, média e alta. 
A.6) Grau de controle: é função dos fatores que alteram o sentido geral da drenagem, tais como orientação e angularidade. Quanto ao grau de controle o padrão de drenagem pode ser classificado em - não controlado, ou com graus de controle baixo, médio ou alto.

A.7) Tipo ou modelo: refere-se à semelhança entre o esquema em planta dos canais de uma rede de drenagem, ou de parte dela, e objetos ou conceitos geométricos, tais como - modelos dendrítico ou arborescente, paralelo, retangular, radial, etc. Devido ao fato dos modelos de padrão de drenagem serem influenciados por muitos fatores, como declividades regionais, desigualdades na dureza das rochas e controle estrutural, os quais são extremamente úteis na interpretação de feições geomórficas, o seu estudo representa um dos meios mais práticos para o entendimento do controle litológico e estrutural na evolução da fisiografia local (THORNBURY, 1954).

Das características sugeridas por LUEDER (1959), não se utiliza, apenas, o grau de integração, que se refere à maior ou menor definição do percurso dos canais de drenagem. Tal procedimento deve-se à dificuldade na obtenção da informação a partir das imagens, para a área estudada, que permita uma caracterização correta da rede de drenagem quanto ao grau de integração dos canais, notadamente na escala $1: 250.000$. 
B) Características quantitativas

A determinação de índices quantitativos da rede de drenagem possibilita inferências sobre diversas condições do terreno, não apresentando a subjetividade da caracterização descritiva (HORTON, 1945).

Os índices de drenagem que se empregam neste estudo são a densidade de drenagem (Dd), a frequência de rios ( $\mathrm{Fr}$ ), o comprimento médio de rios ( $\mathrm{Lm}$ ) e a razão de textura $(\mathrm{T})$.

Na determinação desses índices tradicionalmente são empregadas unidades amostrais constituídas ou por bacias hidrográficas ou por amostras circulares (de área variável de acordo com a escala das imagens fotográficas utilizadas). Porém, no presente trabalho adota-se como unidade amostral a própria unidade fisiográfica. Essas unidades, embora de formas e dimensões variáveis, apresentam homogeneidade individual pronunciada, em relação a rede de drenagem e ao relevo, o que sugere uma provável homogeneidade também quanto aos aspectos morfológicos e funcionais dos solos, justificando assim a sua adoção como unidade amostral (VETTORAZZI, 1988).

B.1) Densidade de drenagem (Dd):

$\mathrm{Dd}=\mathrm{Lt} / \mathrm{A}$ sendo, $\mathrm{Lt}$ o comprimento total de rios (canais) das diversas ordens, em km, e A a área da amostra, em $\mathrm{km}^{2}$. 
B.2) Frequência de rios (Fr):

$\mathrm{Fr}=\mathrm{Nt} / \mathrm{A}$ onde, Nt é o número total de rios (HORTON, 1945) e A é a área da amostra, em $\mathrm{km}^{2}$.

B.3) Comprimento médio de rios ( $\mathrm{Lm})$ :

$\mathrm{Lm}=\mathrm{Lt} / \mathrm{Nt}$ sendo, $\mathrm{Lt}$ o comprimento total de rios, em $\mathrm{km}$, e Nt o número total de rios na amostra.

B.4) Razão de textura (T):

$\mathrm{T}=\mathrm{Nt} / \mathrm{P}$ onde, Nt é o número total de rios (canais) da unidade fisiográfica e $\mathrm{P}$ seu respectivo perímetro em km, conforme SMITH (1950), com modificação de FRANÇA (1968).

\subsubsection{Relevo}

Quanto ao padrão de relevo, as unidades fisiográficas são caracterizadas de acordo com os elementos: tipo e classe de relevo, comprimento das vertentes e posição topográfica. 
A) Tipo de relevo: definido pela relação entre infiltração e escoamento superficial (deflúvio) das águas provenientes de precipitação pluvial sobre o terreno, sendo função principalmente da declividade e posição topográfica. Assim, três são os tipos principais de relevo, com base no SOIL SURVEY STAFF (1951), que podem ocorrer (normal, excessivo e subnormal). No relevo normal há certa equivalência entre o total de água infiltrada e a escoada superficialmente no terreno, permitindo o desenvolvimento normal do solo e geralmente, está associado a solos profundos, como Latossolos e Podzólicos. No relevo excessivo, em função de altos valores de declividade do terreno, o deflúvio é mais intenso que a infiltração, ocasionando um predomínio da erosão sobre os demais fatores de formação do solo; normalmente está relacionado a solos rasos, como os Litólicos. O relevo subnormal aparece em depressões no terreno (normalmente fundos de vale), com baixas declividades e camadas de impedimento no subsolo que favorecem acúmulo de águas; estão normalmente associados a Solos Hidromórficos e Aluviais.

B) Classe de relevo: em relação à movimentação (repetição de formas) do relevo e às declividades locais, o terreno pode ser classificado em - plano, suavemente ondulado, ondulado, fortemente ondulado, montanhoso e escarpado. Tanto a classe quanto o tipo de relevo são inferidos sobre as imagens, com base em elementos como textura fotográfica, efeito de sombras e uso da terra. No caso específico da classe de relevo, adota-se também o procedimento sugerido por VETTORAZZI et al. (1987), através do qual as classes de declividade do terreno são estimadas com base no padrão da rede de drenagem superficial observado nas imagens orbitais. 
C) Comprimento das vertentes: com um escalímetro são medidos os comprimentos das vertentes, calculando-se posteriormente um valor médio para cada unidade fisiográfica. As medições são feitas diretamente sobre as imagens fotográficas, recobertas pelos mapas de unidades fisiográficas em acetato transparente. Devido à imprecisão esperada dos resultados, em função principalmente do material fotográfico empregado (imagem de radar em escala pequena), opta-se pela transformação dos resultados numéricos médios obtidos para cada unidade em dados qualitativos, ou seja, as vertentes são classificadas em - curtas (com menos de 100 m), médias (entre 100 m e $250 \mathrm{~m}$ ), longas (entre $250 \mathrm{~m}$ e $500 \mathrm{~m}$ ) e muito longas (com mais de $500 \mathrm{~m}$ ), conforme SOIL SURVEY STAFF (1951).

D) Posição topográfica: na definição da posição topográfica ocupada pela unidade fisiográfica, emprega-se a seguinte classificação - topo da vertente, terço superior da vertente, terço médio da vertente (meia-encosta), terço inferior da vertente (sopé). $\mathrm{Na}$ ausência de áreas significativas, de planícies aluviais, não se inclui na classificação uma posição topográfica que designasse os fundos planos de vales, entre uma vertente e outra.

\subsubsection{Caracterização pedológica das unidades fisiográficas}

A determinação das unidades de solo predominantes nas unidades fisiográficas é feita através dos dados do trabalho de campo e do mapa publicado do 
levantamento pedológico realizado por PFEIFER (1981/82). No citado levantamento, a densidade de pontos de observação do solo correspondente é classificado em nível pormenorizado, sendo coletado material, dos horizontes de perfís localizados em vários pontos, com posterior análise de laboratório.

Os dados utilizados para a caracterização pedológica das unidades fisiográficas deste trabalho, referem-se a 37 pontos de observação, dos quais 09 (perfís) apresentavam também dados de análises física e química em laboratório. Esses pontos, demarcados na carta topográfica utilizada no tabalho de campo, são devidamente transferidos para os mapas de unidades fisiográficas, estabelecendo-se a relação entre cada unidade e os pontos correspondentes, permitindo assim a identificação do(s) solo(s) predominante(s) em cada uma delas.

Nos casos de unidades fisiográficas sem pontos de observação ou com números de pontos insuficientes para caracterização, recorre-se ao mapa de solos como fonte complementar de informações.

\subsubsection{Reambulação}

Realiza-se a reambulação (checagem de campo) com a finalidade de proporcionar um contato direto com a fisiografia e as principais unidades de solo ocorrentes na área de estudo, bem como para sanar dúvidas apresentadas no decorrer da interpretação das imagens, consequentemente, tal procedimento permite uma melhor análise e discussão dos resultados. 
A checagem não é sistematizada, consistindo em se percorrer a Ilha do Cardoso em um trajeto pré-determinado, de maneira a cobrir áreas de interesse principalmente em termos de solos e relevo.

\subsubsection{Análise estatística}

\subsubsection{Introdução}

O tratamento estatístico dos dados obtidos é elaborado através de programas do "Statistical Analysis System" (SAS, 1987) para computadores pessoais (versão 6.04). Este sistema, como o nome indica, é uma coleção de programas ("pacote") específicos para análises estatísticas.

A Análise Multivariada é o ramo da estatística que objetiva o resumo, a representação e a interpretação de dados amostrados a partir de populações nas quais em cada unidade experimental são avaliadas diversas variáveis. A justificativa para medir diversas variáveis em cada unidade é que nenhuma das variáveis individualmente consegue caracterizar de maneira adequada a unidade, ou consegue discriminar os indivíduos com relação a qualquer critério que seja empregado.

Para poder receber tratamento matemático, os dados qualitativos (referentes às características descritivas da rede de drenagem e do relevo) são transformados em valores numéricos, conforme codificação apresentada a seguir: 
A) Rede de drenagem

A.1) Densidade

3 - muito baixa

4 - baixa

5 - média

6 - alta

7 - muito alta

A.2) Grau de uniformidade

3 - não uniforme

4 - pouco uniforme

5 - uniforme

A.3) Ângulos de junção

3 - agudos fechados

4 - agudos abertos

5 - retos

6 - obtusos

A.4) Orientação

3 - não orientada

4 - pouco orientada

5 - orientada 
A.5) Angularidade

3 - baixa

4 - média

5 - alta

A.6) Grau de controle

3 - muito baixo (rede não controlada)

4 - baixo

5 - médio

6 - alto

A.7) Tipo ou modelo

3 - dendrítico

4 - paralelo

5 - subparalelo

6 - retangular

7 - subretangular

Quando a amostra (unidade fisiográfica) não apresenta canais de drenagem (rede de drenagem ausente), o código empregado é o número 1 e quando a rede de drenagem é insuficiente para caracterização, recebe o código 2 . 
B) Relevo

B.1) Tipo

1 - subnormal

2 - normal

3 - normal a excessivo

4 - excessivo

B.2) Classe

1 - plano

2 - suave ondulado

3 - ondulado

4 - ondulado a forte ondulado

5 - forte ondulado

6 - forte ondulado a montanhoso

7 - montanhoso

B.3) Comprimento das vertentes

1 - não aplicável (amostra ocupando posição de interflúvio)

2 - curtas $<100 m$

3 - médias 100 - 250m

4 - longas $250-500 m$

5 - muito longas $>500 \mathrm{~m}$

6 - amostra insuficiente para caracterização 
B.4) Posição topográfica

1 - terço inferior da vertente (ti)

2 - terço médio da vertente $(\mathrm{tm})$

3 - terço superior da vertente (ts)

4 - topo da vertente (tv)

$5-\mathrm{ti}+\mathrm{tm}$

$6-\mathrm{ti}+\mathrm{tm}+\mathrm{ts}$

$7-\mathrm{ti}+\mathrm{tm}+\mathrm{ts}+\mathrm{tv}$

$8-\mathrm{tm}+\mathrm{ts}$

$9-\mathrm{tm}+\mathrm{ts}+\mathrm{tv}$

10- ts $+\mathrm{tv}$

11- amostra insuficiente para caracterização

\subsubsection{Passos da análise}

1) Análise de agrupamentos

Dado um conjunto de unidades conhecidas somente por uma listagem de suas variáveis, o objetivo da análise de agrupamentos é encontrar a melhor maneira de descrever o padrão de similaridades mútuas das unidades.

O primeiro passo da análise é a definição de grupos homogêneos de unidades fisiográficas, em função de suas características da rede de drenagem e do 
relevo. Essa definição é realizada através da Análise de Agrupamentos ("Cluster Analysis").

Análise de Agrupamentos é um nome genérico para uma série de métodos matemáticos que podem ser usados para definir quais os elementos, dentro de um dado conjunto, são similares, ou seja, para fazer classificações. Com base em ROMESBURG (1984), é feita a seguir uma descrição resumida desse tipo de análise.

Os métodos de análise de agrupamentos seguem um conjunto determinado de passos, dos quais os principais são:

(1) coletar uma matriz de dados, cujas colunas são reservadas para os elementos a serem analisados, ficando as linhas com os atributos que descrevem os elementos;

(2) opcionalmente, padronizar a matriz de dados;

(3) calcular os valores de um coeficiente de semelhança, para medir as similaridades entre todos os pares de elementos;

(4) usar um método de agrupamento para processar os valores do coeficiente de semelhança, o que resulta num diagrama chamado de árvore, ou dendrograma ou fenograma, que mostra a hierarquia de similaridade entre todos os pares de elementos. Os grupos ("clusters") podem então ser definidos através desse diagrama. 
Dentro do conjunto de passos tem-se a liberdade de escolher caminhos alternativos para padronizar a matriz de dados, escolher um coeficiente de semelhança e um método de agrupamento. Logo, o pesquisador tem amplas possibilidades de adaptar a análise a aplicações específicas.

Após a obtenção da matriz de dados, onde os elementos são as unidades fisiográficas e os atributos são características de drenagem e de relevo, realiza-se a padronização da matriz, ou seja, os atributos originais são convertidos em novos atributos adimensionais. Há duas razões principais para se padronizar a matriz. Primeira razão: remover efeitos arbitrários que podem afetar a análise, provocados pelas unidades escolhidas para medir os atributos. Segunda razão: a padronização faz com que os atributos contribuam mais equitativamente com as similaridades entre elementos; por exemplo, se a variação de valores de um certo atributo é muito maior que a de um outro, então o primeiro terá maior peso na determinação das similaridades entre os elementos.

A padronização é feita através da aplicação à matriz de dados de uma função de padronização.

Uma matriz possuindo $\mathrm{n}$ atributos, $\mathrm{i}=1,2, \ldots \mathrm{n}$, e $\mathrm{t}$ elementos, $\mathrm{j}=$ $1,2, \ldots$ t, terá o valor do dado para a i-ésimo atributo e j-ésimo elemento designado por $X_{\mathrm{ij}}$. $\mathrm{O}$ valor correspondente na matriz padronizada será designado por $\mathrm{Z}_{\mathrm{ij}}$.

A função de padronização aplicada aos dados deste trabalho é:

$$
Z_{i j}=X_{i j}-\bar{X}_{i} / S_{i}
$$


isto é, no cálculo do valor padronizado $\mathrm{Z}_{\mathrm{ij}}$ para o i-ésimo atributo e j-ésimo elemento, toma-se o valor correspondente $X_{i j}$ na matriz subtrai-se dele a média $\bar{X}_{i}$ de valores do i-ésimo atributo e divide-se o resultado pelo desvio padrão $S_{\mathrm{i}}$ dos valores do i-ésimo atributo.

A etapa seguinte da análise é a determinação do coeficiente de semelhança, o qual mede a similaridade entre cada par de elementos do conjunto.

Um dos coeficientes que pode ser empregado é a Distância Euclideana. Como o nome sugere, mede a distância entre dois elementos, quando são representados por pontos em um espaço bidimensional formado por seus atributos. Esta distância é calculada usando-se o teorema de Pitágoras.

A notação da Distância Euclideana entre dois elementos j e k é $e_{j k}$, onde j é o menor dos dois números de identificação do elemento. $O$ coeficiente $e_{j k}$ não pode ser menor do que 0,0 (zero), uma vez que este valor indica a máxima semelhança entre os elementos, ou seja, são idênticos quando $e_{j k}=0,0$.

O cálculo da Distância Euclideana é feito da seguinte maneira:

$$
e_{j k}=\left[\sum_{i=1}^{n}\left(X_{i j}-X_{i k}\right)^{2}\right]^{1 / 2}
$$

ou seja, para um dado par de elementos, atributo por atributo são tomadas as diferenças entre seus valores; as diferenças são elevadas ao quadrado e somadas, sendo posteriormente extraída a raiz quadrada desta soma. 
O coeficiente de semelhança empregado neste trabalho é a Distância Euclideana Média $\left(\mathrm{d}_{\mathrm{jk}}\right)$, uma variação de $\mathrm{e}_{\mathrm{jk}}$, diferindo deste por ter em seu cálculo a média dos quadrados das diferenças, dividindo-os por $\mathrm{n}$ :

$$
d_{j k}=\left[\sum_{i=1}^{n}\left(X_{i j}-X_{i k}\right)^{2} \ln \right]^{1 / 2}
$$

Uma das vantagens de $d_{j k}$ é poder ser empregado quando a matriz de dados contém valores perdidos.

Calculados os coeficientes de semelhança, passa-se à execução do método de agrupamento. O método empregado neste trabalho é o "Average Linkage", onde a distância entre dois grupos é a distância média entre pares de observações, um em cada grupo. Este método tende a formar grupos com a mesma variância.

A execução do método de agrupamento possibilita a construção de um diagrama (árvore de dendrograma ou fenograma), que torna mais fácil a verificação da similaridade entre todos os pares de elementos analisados.

A decisão de onde "cortar" o fenograma para se definirem os grupos (classificação) depende de uma combinação de fatores. Geralmente, segundo ROMESBURG (1984), é desejável que os grupos sejam poucos em número e bem definidos. Entretanto, o propósito de uma classificação também é um fator a ser considerado, ou seja, o fenograma deve ser cortado em um ponto que atenda aos propósitos do trabalho. Normalmente isto coincide com a formação de poucos grupos e bem definidos. 
DU TOIT et al. (1986) citam que a escolha, um tanto subjetiva, de um valor através do qual os grupos são eventualmente formados, pode ser considerada uma desvantagem na análise de agrupamentos hierárquica. Segundo esses autores, deve-se ter em mente, que a análise de agrupamentos é uma análise determinística exploratória e é usada somente para identificar grupos relativamente homogêneos de observações em um conjunto de dados simples, e raramente como uma técnica inferencial clássica.

Na Figura 9, conforme VETTORAZZI (1988), são exemplificadas três situações de corte do fenograma. O corte em A, no valor de 24,0 para o coeficiente de semelhança, não irá separar os cinco elementos, mantendo-os todos em um único grupo. Cortando-se em B (coeficiente de semelhança igual a 16,0), há a separação dos elementos em dois grupos: o primeiro formado pelos objetos 3,4 e 2, e o segundo pelos elementos 1 e 5 . A medida que aumenta o grau de similaridade entre cada par de elementos, ou seja, diminui o coeficiente de semelhança, a tendência é aumentar o número de grupos formados. Um corte feito ao nível do valor 8,0 (corte $\mathrm{C}$ ), por exemplo, resulta na formação de três grupos: no primeiro grupo encontram-se os elementos 3 e 4, no segundo o elemento 2 e no terceiro os elementos 1 e 5 .

O procedimento "PROC TREE" do sistema SAS, empregado neste trabalho, não produz um fenograma ou dendrograma típico, mas sim um mapa de agrupamentos ("cluster map"), cuja interpretação também não oferece maiores dificuldades. 


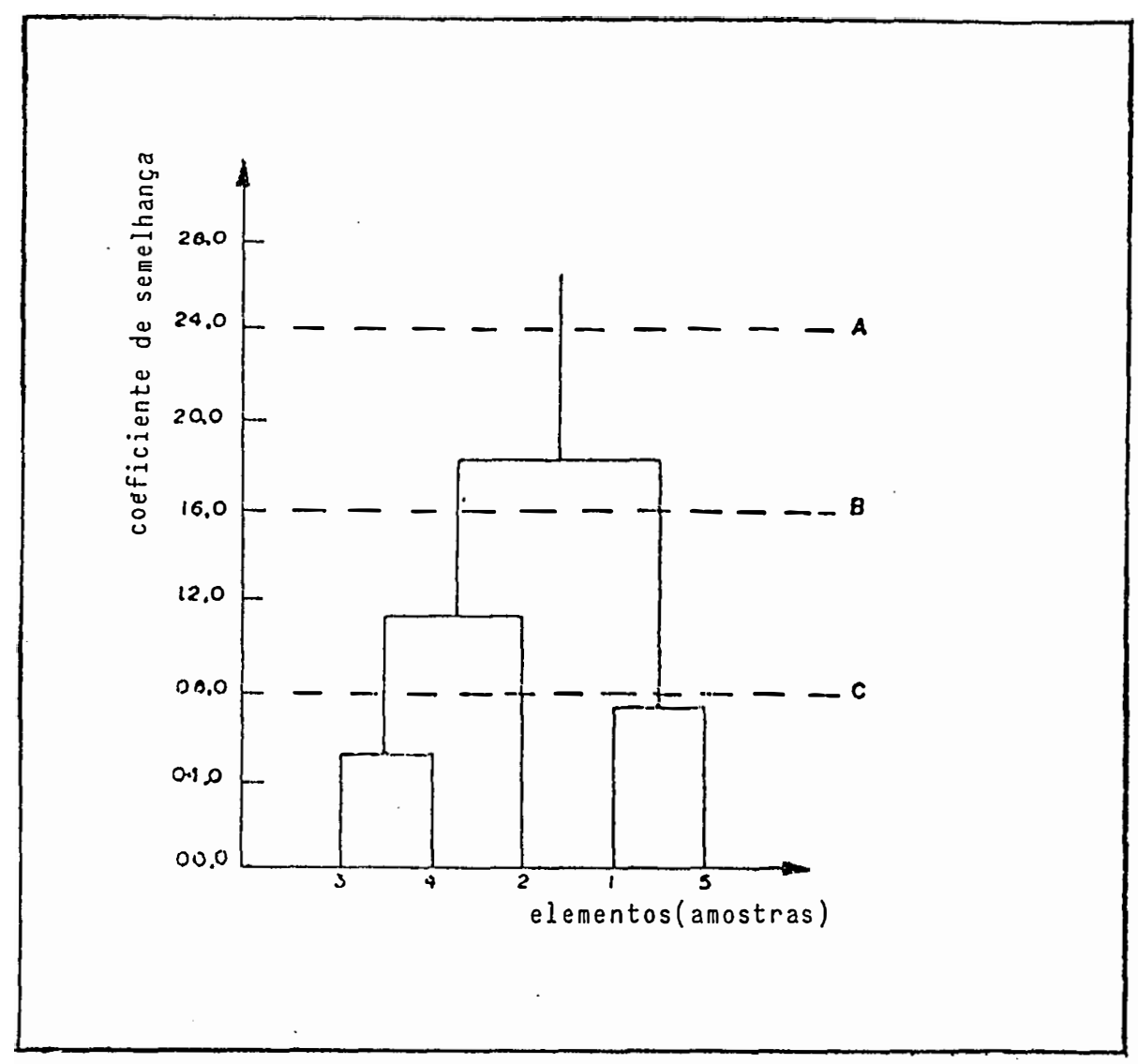

Figura 9 - Exemplo hipotético de dendrograma.

Fonte: VETTORAZZI (1988). 
2) Cálculo das medidas de tendência central e de dispersão

Para cada variável (elemento de interpretação), dentro de cada um dos grupos definidos, são calculadas medidas de tendência central (média aritmética e moda) e de dispersão (desvio padrão e coeficiente de variação). Estas medidas são utilizadas na caracterização de cada grupo através das variáveis estudadas.

3) Análise de variância

Para analisar a eficiência de cada variável na separabilidade dos grupos, são aplicados para cada elemento de:

a) interpretação quantitativa, o teste $\mathrm{F}$ e o teste de Tukey ao nível de $5 \%$ de probabilidade (GOMES, 1987); e

b) interpretação qualitativa, o teste de Wilcoxon e o teste de Kruskal-Wallis ao nível de $5 \%$ de probabilidade (CAMPOS, 1983). 


\section{RESULTADOS E DISCUSSÃO}

Os resultados obtidos estão apresentados numa sequência correlata com a utilizada no ítem Material e Métodos, dispostos em Figuras e Tabelas referentes aos resultados obtidos de cada produto de sensor remoto, isto é, de fotografias aéreas (1:25000), imagem TM/Landsat - composição colorida 3.4.5 - (1:50000) e imagem de Radar (1:250000), com a finalidade de não torná-los repetitivos e facilitar a visualização e interpretação comparativa das unidades fisiográficas estudadas.

\subsection{Mapas da rede de drenagem superficial}

Os mapas de drenagem do Parque Estadual da Ilha do Cardoso, obtidos através das aerofotografias, imagens de satélite e de radar, podem ser observados nas Figuras 10, 11 e 12, respectivamente.

Pela Figura 10, mapa da rede de drenagem extraído de fotografias aéreas na escala aproximada de 1:25000 nota-se, concordado com FRANÇA (1968), que a composição das redes de drenagem, envolvendo número e comprimento dos segmentos de rios das diversas ordens, possue alta significância hidrológica e reflete melhor as 


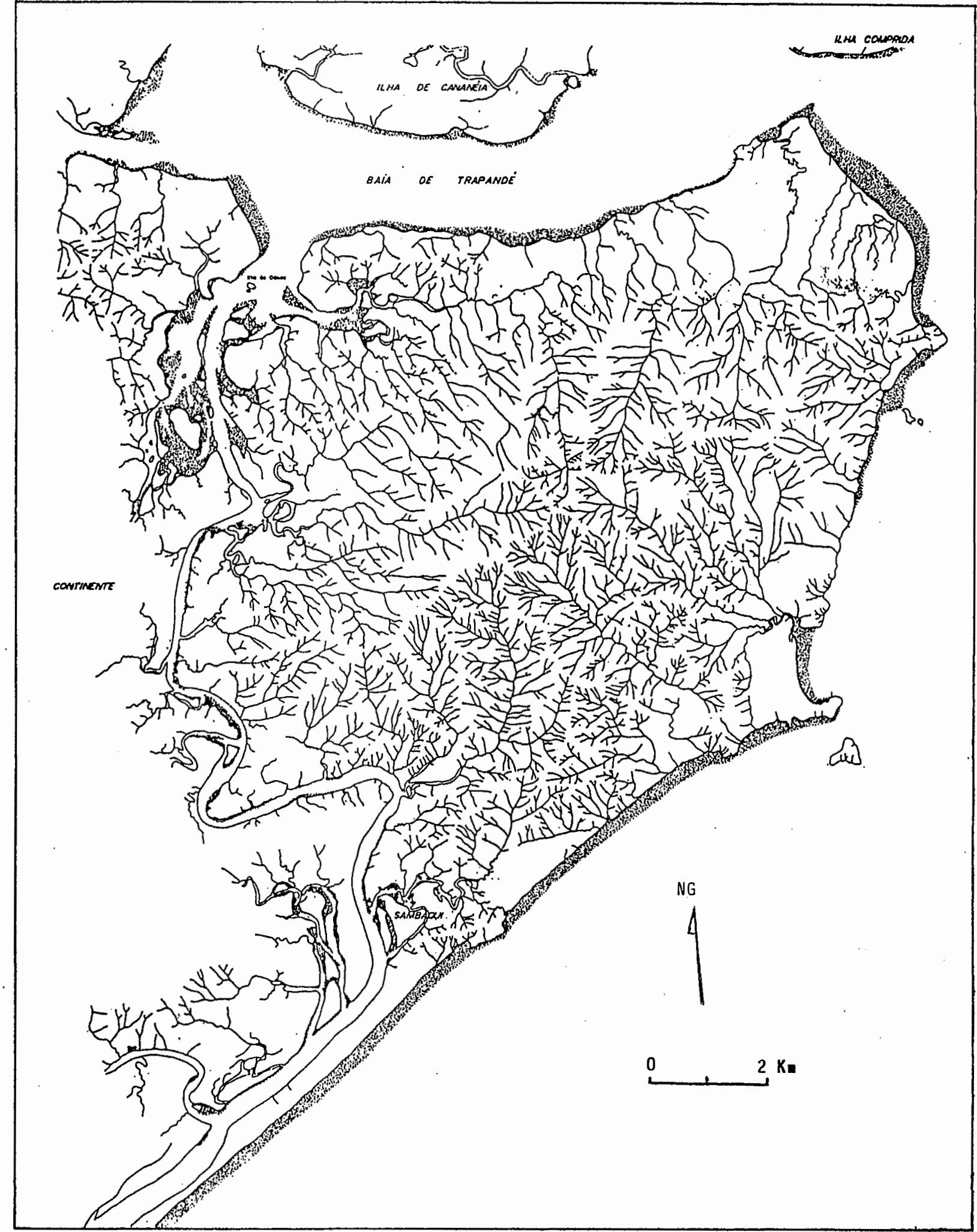

Figura 10 - Mapa da.rede de drenagem superficial do P.E. da Ilha do Cardoso, SP. (extraído de fotografias aéreas da cobertura aerofotogramétrica do Estado de São Paulo, de 1972, na escala aproximada de $1: 25.000)$. 


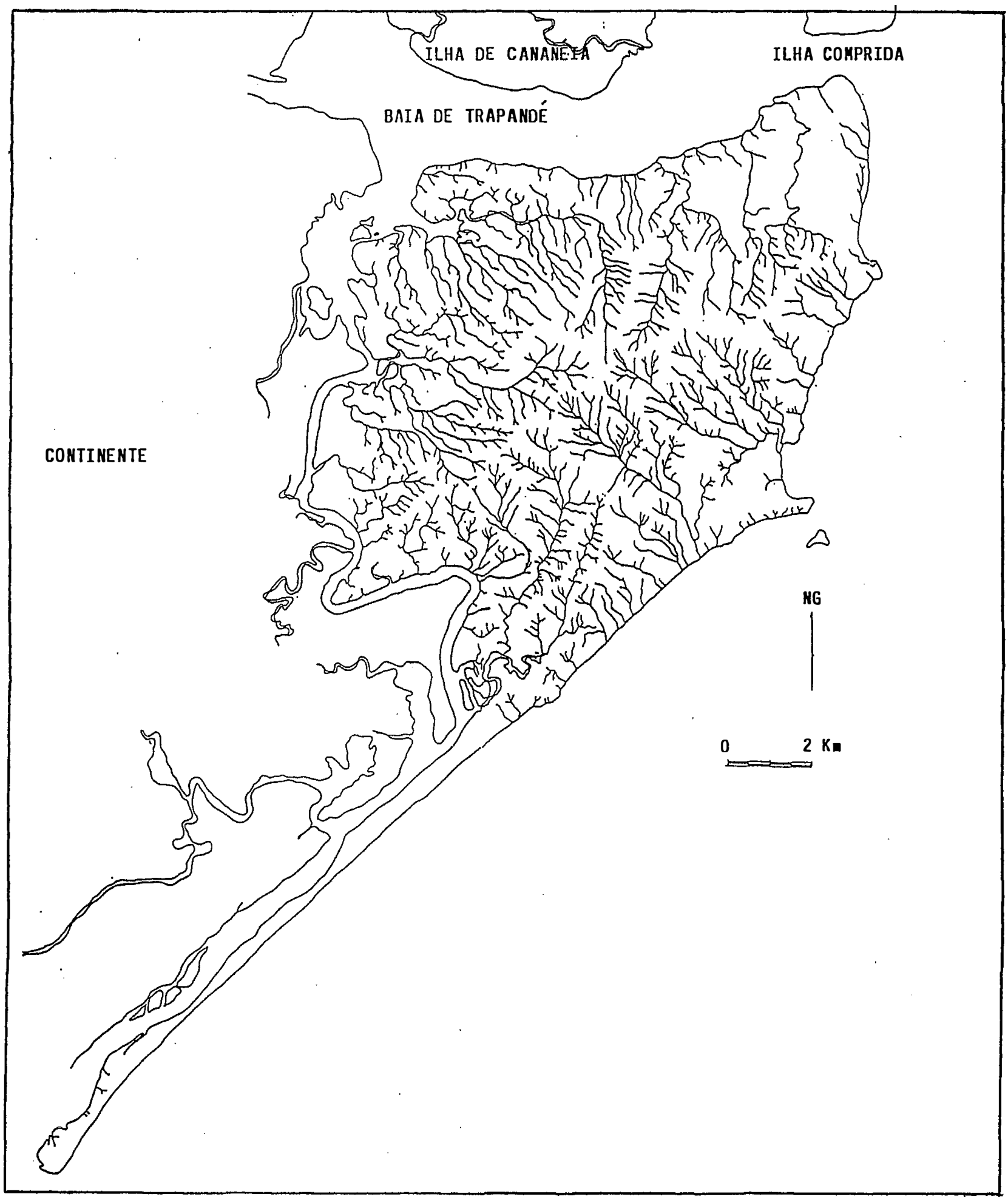

Figura 11 - Mapa da rede de drenagem superficial do P.E. da Ilha do Cardoso, SP. (extraído de imagem TM/LANDSAT, composição colorida 3.4.5, de 22.03.1992, na escala de $1: 50.000)$. 


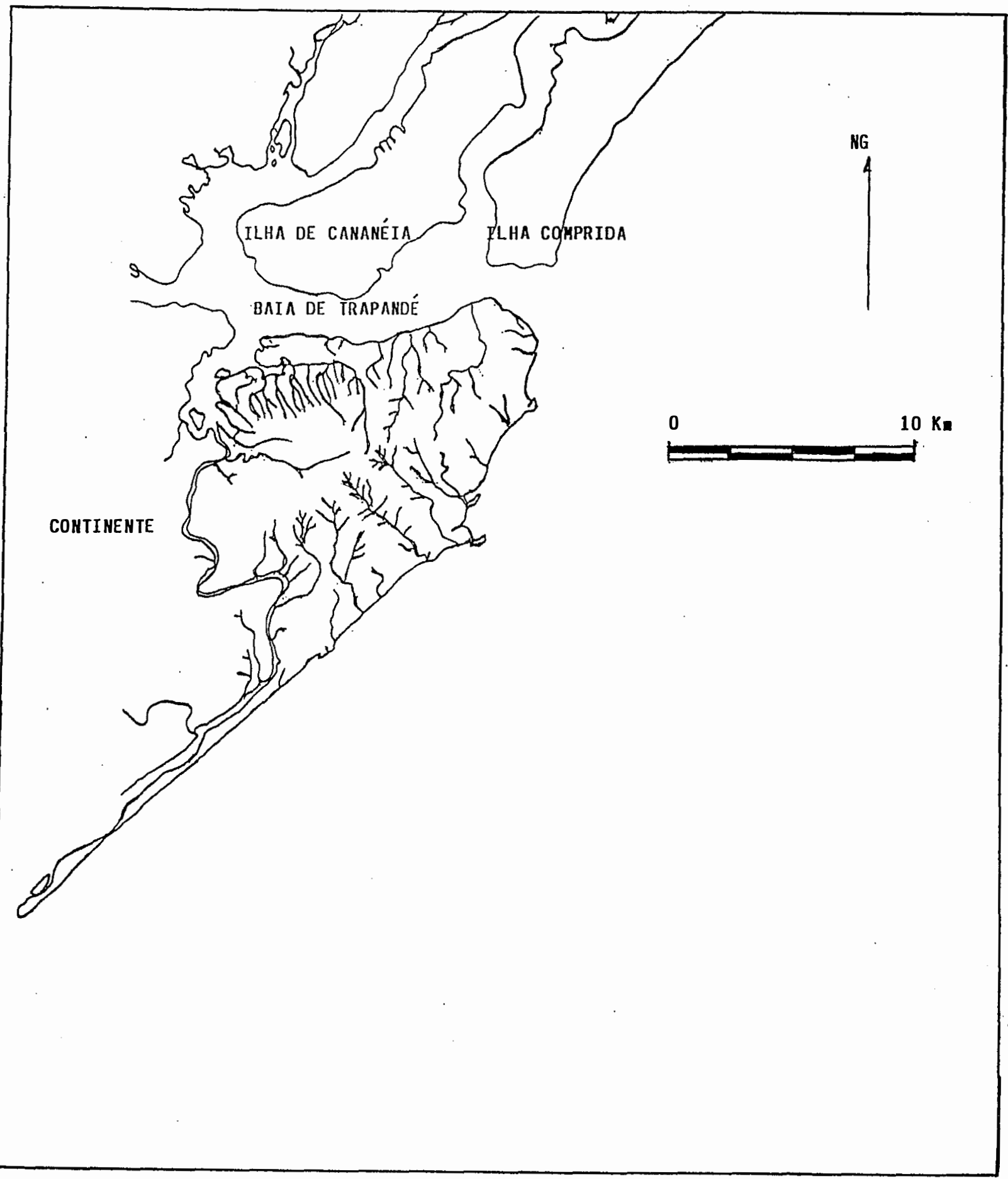

Figura 12 - Mapa da rede de drenagem superficial do P.E. da Ilha do Cardoso, SP. (extraído de imagem de Radar GEMS 1000, banda X, cópia "off set" do mosaico semicontrolado de 1976 , na escala de $1: 250.000$ ). 
diferenças entre solos, do que o padrão de drenagem em si. Segundo o autor, o padrão de drenagem, por ligar-se mais aos modelos de distribuição de rios e tributários tem mais significância com respeito a controles geológico e topográfico dos sistemas de drenagem. Estas observações corroboram com as de HORTON (1945) e STRAHLER (1952 e 1957). Portanto, no delineamento da rede de drenagem, a fotografia aérea na escala aproximada de 1:25000, é de grande utilidade, pois permite um nível de detalhamento que facilita a extração de informações e, consequentemente, a interpretação.

Comparativamente, pelo exame da Figura 11, a utilização de imagens orbitais, em estudos envolvendo rede de drenagem, apresenta como uma de suas limitações a dificuldade de obter-se o traçado completo da rede, conforme verificado por TOWNSHEND et al. (1979), EPIPHANIO et al. (1983), COVRE et al. (1986) e VETTORAZZI (1988). Porém, com o emprego de imagem TM/Landsat - composição colorida 3, 4 e 5 - na escala 1:50000, pode-se obter uma aproximação maior do traçado real da rede de drenagem, devido a referida imagem reunir diferentes bandas que proporcionam um maior número de informações espectrais e espaciais sobre o terreno. Este resultado, no que diz respeito às bandas referentes às faixas do visível e do infravermelho próximo [TM-3 (630-690 nm), TM-4 (760-900 nm) e TM-5 (1550-1750 nm)], está de acordo com as observação de VALÉRIO FILHO (1984) e VETTORAZZI (1988). Em função da absorção da energia eletromagnética pela umidade presente na biomassa florestal do P.E. da Ilha do Cardoso e, principalmente, pela combinação das 
bandas aliadas ao contraste proporcionado pela falsa cor, em áreas de ocupação, em canais de drenagem e em áreas com cobertura vegetal natural, há uma maior facilidade no delineamento dos segmentos de rios.

Pelo exame da Figura 12 nota-se que as dificuldades encontradas no traçado da rede sobre imagem de radar na escala 1:250.000 em relação às anteriores, são maiores mas esperadas, visto que, a medida que se diminui a escala dos produtos de sensores remotos, torna-se mais difícil a identificação dos canais de pequenas ordens e consequentemente, diminui o nível de detalhamento do mapa da rede de drenagem. Para compensar os problemas advindos da escala e resolução do Radar de Visada Lateral, lança-se mão dos benefícios da tonalidade e da textura que produzem o efeito sombra, isto é, a distribuição média do elemento tonal, a textura individual, e a combinação de ambos que formam o padrão topográfico. As variações topográficas do terreno imageado afetam a distribuição do sombreamento provocado pelas encostas sem retorno do sinal, com grande frequência de ocorrência de sombras caracterizando a rugosidade do terreno, portanto, há uma relação direta entre a rugosidade da superfície e a consequente textura registrada nas imagens de radar. Tal efeito auxilia a interpretação monoscópica não encontrada em produtos de outros sensores remotos. Esta também é a opinião de KOOPMANS (1973), de PARRY (1974) e de VALÉRIO FILHO (1984). 


\subsection{Mapas das unidades fisiográficas}

A estratificação do terreno em áreas homogêneas quanto ao padrão da rede de drenagem e do relevo, segundo procedimento sugerido por GOOSEN (1967), é aplicado nos três produtos de sensores remotos, isto é, em fotografias aéreas (escala aproximada de 1:25000), imagem de satélite (1:50.000) e em imagem de radar (1:250.000). O resultado é o mapeamento das unidades fisiográficas, nas três escalas, que são apresentados nas Figuras 13, 14 e 15 respectivamente.

A metodologia empregada, isto é, as características do padrão de drenagem e do relevo, revelaram-se bastante úteis na identificação das unidades fisiográficas associadas aos solos, concordando com os resultados obtidos por MONTOYA (1977) e VETTORAZZI (1988).

Quanto às facilidades proporcionadas pelo emprego dos diferentes produtos de sensores remotos e respectivas escalas na delimitação das unidades fisiográficas, pode-se dizer que constituiu-se nas mesmas encontradas para a fotointerpretação da rede de drenagem, em virtude das potencialidades e limitações de cada material empregado. Pelos motivos expostos e observando-se as Figuras 13, 14 e 15 , nota-se que pela fotointerpretação da rede de drenagem e do relevo em fotografias aéreas - na escala aproximada de 1:25.000 - há a possibilidade de se detectar 28 (vinte e oito) unidades fisiográficas; pela imagem TM/Landsat - composição colorida 3.4.5, na escala 1:50.000 - 20 (vinte) unidades fisiográficas; e pela imagem de radar - na escala 1:250.000 - apenas 6 (seis) unidades. 


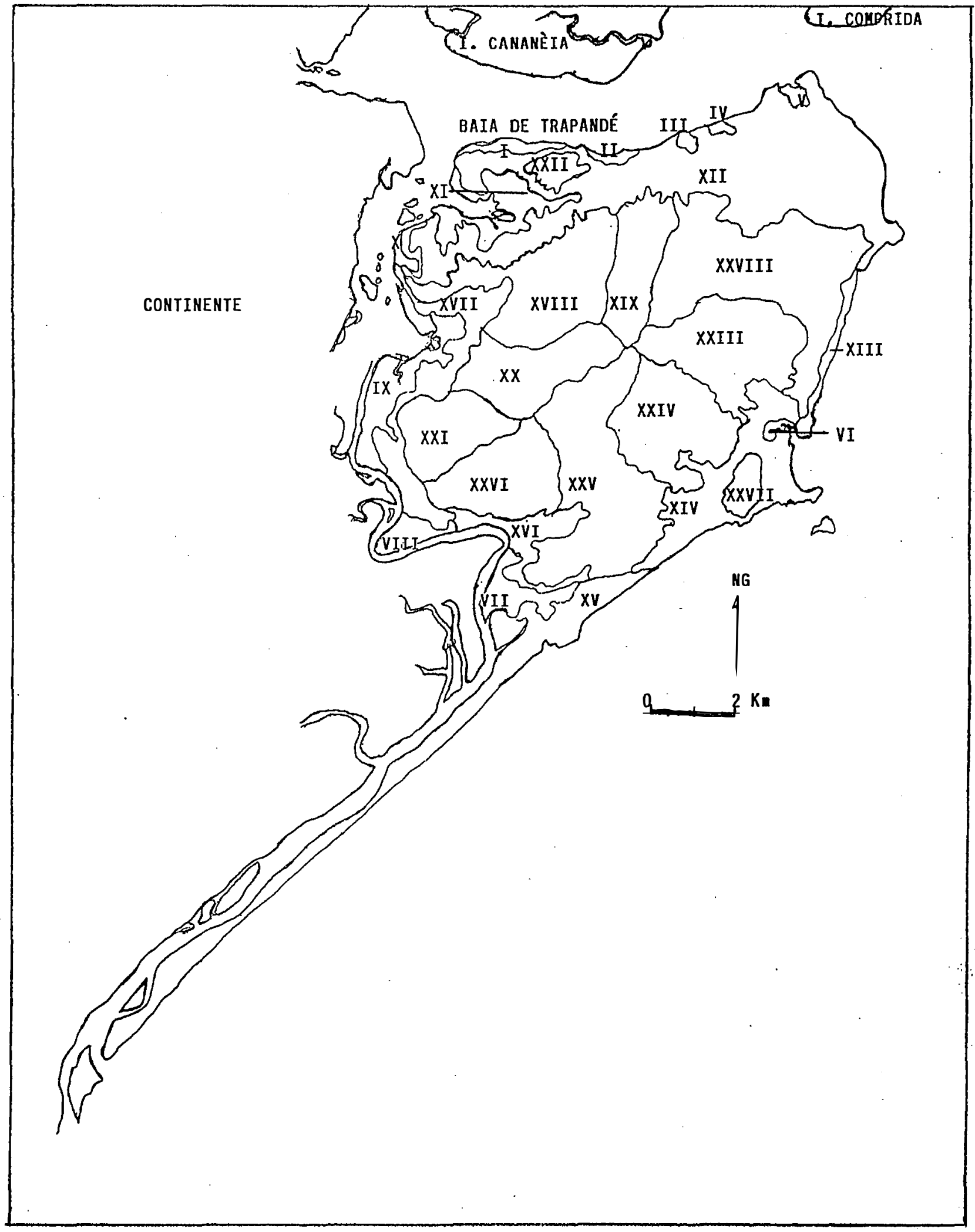

Figura 13 - Mapa de localização das unidades fisiográficas (I a XXVIII). (obtidas de fotografias aéreas de 1972, na escala aproximada de 1 : 25.000). 


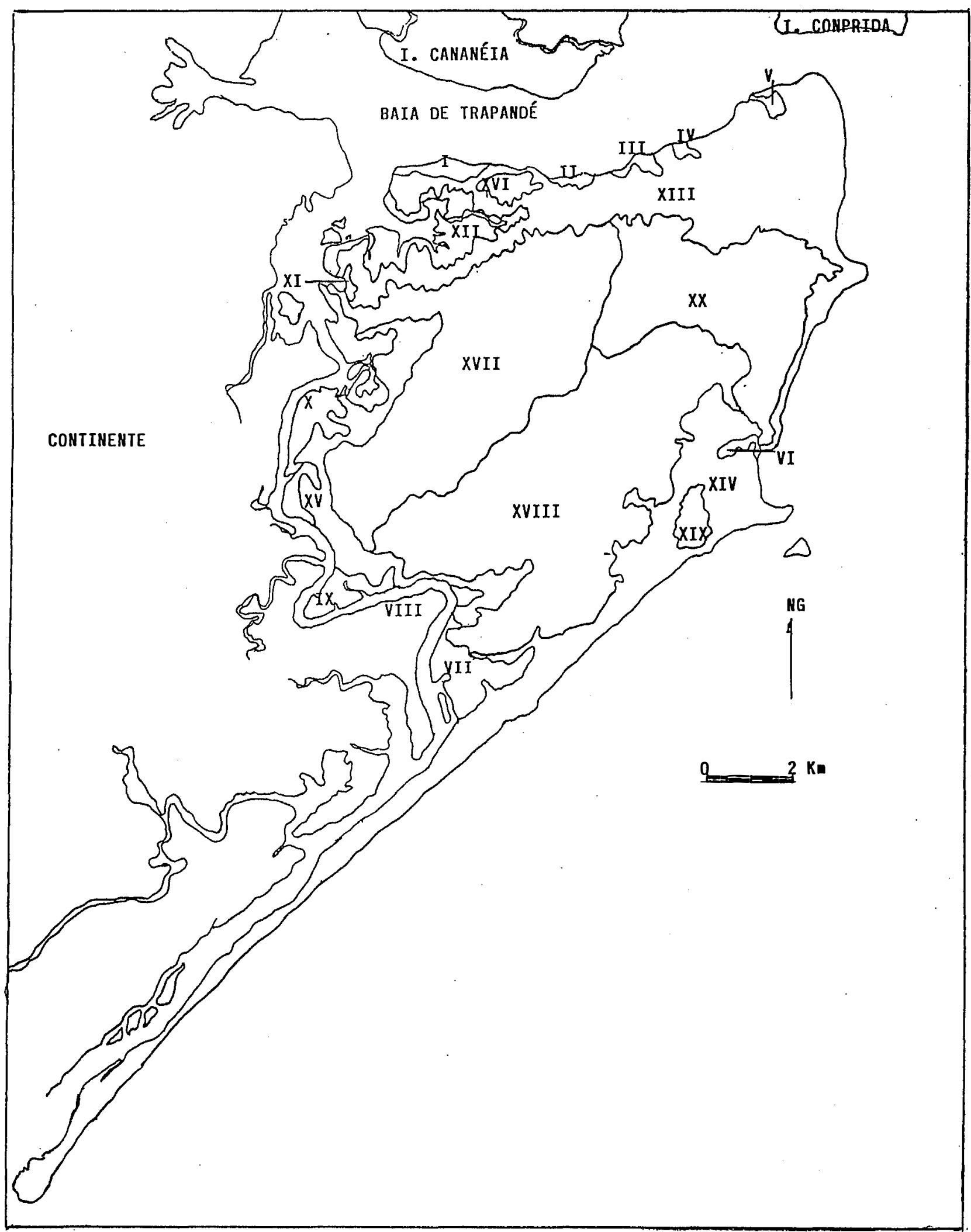

Figura 14 - Mapa de localização das unidades fisiográficas (I a XX).

(obtidas de imagem TM/Landsat, composição colorida 3.4.5, na escala de $1: 50.000)$. 


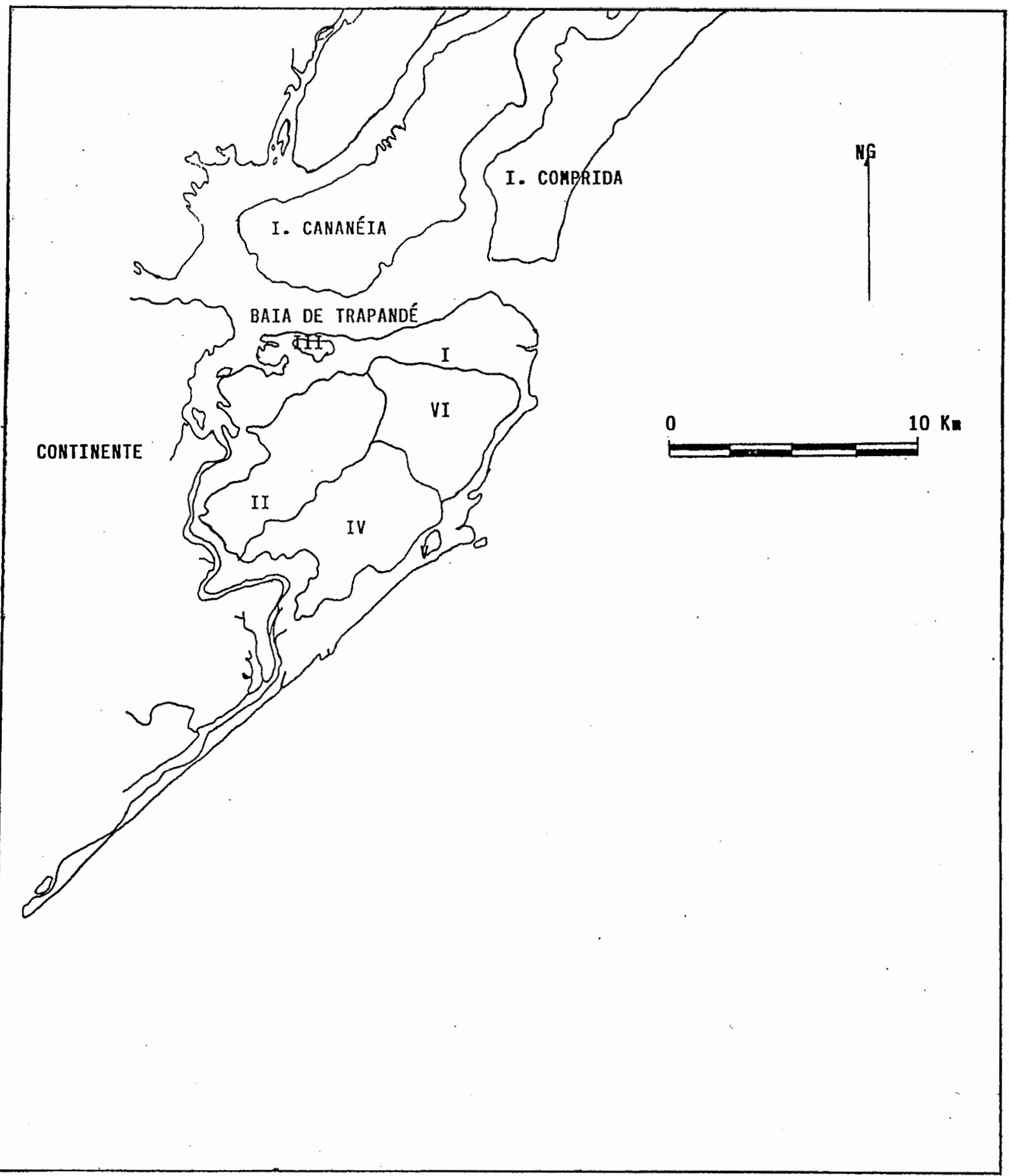

Figura 15 - Mapa de localização das unidades fisiográficas (I a VI). (obtidas de imagem de Radar GEMS 1000, cópia "off set" do mosaico semicontrolado, na escala de $1: 250.000$ ). 


\subsection{Características dimensionais das unidades fisiográficas}

As características quantitativas dos padrões de drenagem superficial, das unidades fisiográficas extraídas de aerofotografias, de imagem TM/Landsat e de imagem de radar, são apresentados nas Tabelas 3, 4 e 5, respectivamente, isto é, para a escala aproximada de 1:25.000, para a escala 1:50.000 e para a escala 1:250.000.

Observando-se as Figuras 13, 14 e 15 e comparando-se os dados apresentados nas citadas Tabelas, pode-se verificar que, poucas observações são equivalentes nas 3 (três) escalas, isto é, das 54 (cinquenta e quatro) unidades fisiográficas mapeadas, apenas 3 (três) são equivalentes nas três escalas estudadas (observações 22/44/51; 27/47/53; e 28/48/54), correspondendo à 5,56\% .

Nota-se também que, a interpretação visual das fotografias aéreas e da imagem TM/Landsat possibilitam o delineamento de segmentos de rios de até $4^{\mathrm{a}}$ ordem de ramificação, enquanto que pela interpretação da imagem de radar detecta-se canais de apenas $3^{a}$ ordem de ramificação. Neste caso, a escala impõe limites, tornando-se um fator que deve ser considerado no nível de detalhamento do mapeamento.

Por esse mesmo motivo, o número total de segmentos de rios $(\mathrm{Nt})$ detectados nas 3 (três) escalas é decrescente, bem como o comprimento total (Lt), isto é, maior na escala aproximada de 1:25.000; intermediário na escala 1:50.000 e menor na escala $1: 250.000$. 
Tabela 3 - Características dimensionais das unidades fisiográficas extraídas de fotografias aéreas de 1972, na escala aproximada de $1: 25.000$.

\begin{tabular}{|c|c|c|c|c|c|c|c|c|c|c|c|c|c|}
\hline \multirow{2}{*}{$\begin{array}{l}\text { UNID. } \\
\text { FISIO. }\end{array}$} & \multirow[t]{2}{*}{ 08s. } & \multicolumn{2}{|c|}{ № SEG.RIOS EM } & \multirow{2}{*}{$\frac{\text { CADA }}{3 a}$} & \multirow{2}{*}{$\frac{\text { OROEM }}{4^{\mathrm{a}}}$} & \multirow{2}{*}{$\begin{array}{l}\text { TOTAL } \\
\mathrm{Nt}\end{array}$} & \multicolumn{2}{|c|}{ COMP.SEG.RIOS EM } & \multirow{2}{*}{$\frac{C A D A}{3 \underline{a}}$} & \multirow{2}{*}{$\frac{\text { ORDEM }(\mathrm{Km})}{4 \mathrm{a}}$} & \multirow{2}{*}{$\begin{array}{l}\text { rOTAL } \\
\text { Lt }\end{array}$} & \multirow{2}{*}{$\begin{array}{l}\text { PERIK. } \\
(\mathrm{Km})\end{array}$} & \multirow{2}{*}{$\begin{array}{l}\text { ÁREA } \\
\text { (ha) }\end{array}$} \\
\hline & & $1 \mathrm{a}$ & $2 \underline{a}$ & & & & $1 \mathrm{a}$ & $2^{\mathrm{a}}$ & & & & & \\
\hline I & 1 & 4 & 1 & 0 & 0 & 5 & 0,37 & 0,63 & 0,00 & 0,00 & 1,00 & 3,00 & 41,66 \\
\hline II & 2 & 2 & 0 & 0 & 0 & 2 & 0,37 & 0,00 & 0,00 & 0,00 & 0,37 & 2,60 & 26,88 \\
\hline III & 3 & 4 & 1 & 0 & 0 & 5 & 1,00 & 0,10 & 0,00 & 0,00 & 1,10 & 2,33 & 26,04 \\
\hline IV & 4 & 3 & 1 & 0 & 0 & 4 & 0,93 & 0,33 & 0,00 & 0,00 & 1,26 & 0,96 & 12,08 \\
\hline V & 5 & .4 & 0 & 0 & 0 & 4 & 1,00 & 0,00 & 0,00 & 0,00 & 1,00 & 1,93 & 30,00 \\
\hline VI & 6 & 5 & 0 & 0 & 0 & 5 & 1,33 & 0,00 & 0,00 & 0,00 & 1,33 & 2,30 & 22,71 \\
\hline VII & 7 & 17 & 4 & 0 & 0 & 21 & 2,53 & 1,33 & 0,00 & 0,00 & 3,86 & 8,67 & 145,00 \\
\hline VIII & 8 & 8 & 1 & 0 & 0 & 9 & 2,37 & 0,33 & 0,00 & 0,00 & 2,70 & 4,97 & 99,17 \\
\hline IX & 9 & 29 & 3 & 0 & 0 & 32 & 4.87 & 0,73 & 0,00 & 0,00 & 5,60 & 19,67 & 362,81 \\
\hline$x$ & 10 & 7 & 1 & 0 & 0 & 8 & 0,67 & 0,33 & 0,00 & 0,00 & 1,00 & 4,70 & 46,04 \\
\hline$X I$ & 11 & 34 & 2 & 0 & 0 & 36 & 2,97 & 1,33 & 0,00 & 0,00 & 4,30 & 15,03 & 441,56 \\
\hline XII & 12 & 186 & 46 & 5 & 0 & 237 & 22,60 & 17,06 & 6,50 & 0,00 & 46,16 & 55,98 & 2108,63 \\
\hline XIII & 13 & 25 & 2 & 0 & 0 & 27 & 2.93 & 0,40 & 0,00 & 0,00 & 3,33 & 8,67 & 83,44 \\
\hline XIV & 14 & 100 & 28 & 5 & 0 & 133 & 12,13 & 5,60 & 3,63 & 0,00 & 21,36 & 18,50 & 591,46 \\
\hline XV & 15 & .48 & 13 & 3 & 0 & 64 & 4,50 & 2,67 & 0,97 & 0,00 & 8,14 & $37 ; 00$ & 722,40 \\
\hline XVI & 16 & 64 & 14 & 2 & 0 & 80 & 5,27 & 3,07 & 0,63 & 0,00 & 8,97 & 14,35 & 215,31 \\
\hline XVII & 17 & 69 & 19 & 3 & 0 & 91 & 9,33 & 5,97 & 1,63 & 0,00 & 16,93 & 22,30 & 454,38 \\
\hline XVIII & 18 & 123 & 27 & 5 & 0 & 155 & 19,37 & 8,00 & 2,70 & 0,00 & 30,07 & 17,95 & 730,00 \\
\hline$X I X$ & 19 & 91 & 18 & 3 & 1 & 113 & 12,27 & 4,70 & 1,00 & 2,50 & 20,47 & 8,30 & 362,71 \\
\hline$x x$ & 20 & 80 & 14 & 2 & 0 & 96 & 14,67 & 5,67 & 3,97 & 0,00 & 24,31 & 11,27 & 512,92 \\
\hline XXI & 21 & 80 & 17 & 3 & 0 & 100 & 11,70 & 6,47 & 1,30 & 0,00 & 19,47 & 9,63 & 383,33 \\
\hline$X X I I$ & 22 & 26 & 4 & 1 & 0 & 31 & 2,93 & 0,70 & 0,20 & 0,00 & 3,83 & 4,33 & 82,50 \\
\hline XXIII & 23 & 152 & 37 & 11 & 3 & 203 & 21,67 & 7,87 & 5,93 & 4,20 & 39,67 & 10,07 & 734,06 \\
\hline XXIV & 24 & 161 & 35 & 7 & 1 & 204 & 22,87 & 7,33 & 7,17 & 4,50 & 41,87 & 10,00 & 592,50 \\
\hline$x \times V$ & 25 & 340 & 79 & 23 & 3 & 445 & 43.40 & 17,33 & 7,00 & 3,63 & 71,36 & 21,33 & 1195,00 \\
\hline XXVI & 26 & 116 & 25 & 6 & 0 & 147 & 16,73 & 6,70 & 5,07 & 0,00 & 28,50 & 9,07 & 488,33 \\
\hline XXVII & 27 & 29 & 5 & 0 & 0 & 34 & 3,00 & 0,63 & 0,00 & 0,00 & 3,63 & 3,53 & 97,29 \\
\hline XXVIII & 28 & 198 & 49 & 12 & 2 & 261 & 37,70 & 12,53 & 5,00 & 3.17 & 58,40 & 18,90 & 1172,50 \\
\hline TOTAL & 28 & 2005 & 446 & 91 & 10 & 2552 & 281,48 & 117,81 & 52,70 & 18,00 & 469,99 & - & 11780,71 \\
\hline
\end{tabular}




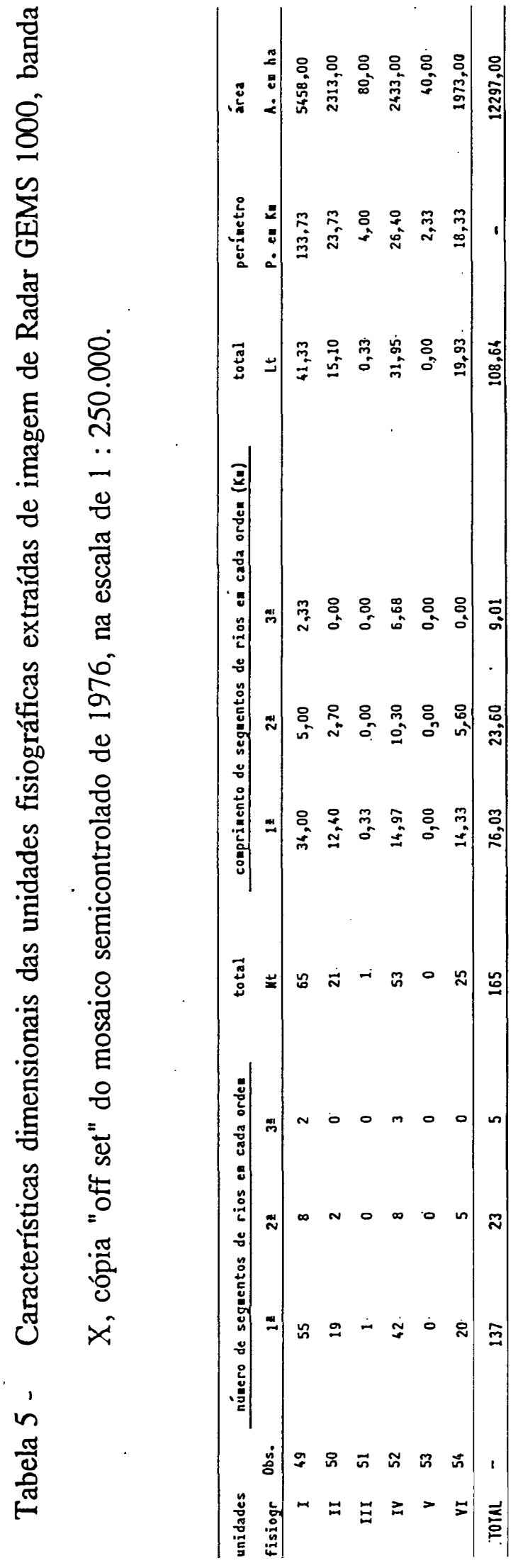


4.4. Características quantitativas e qualitativas da drenagem superficial e do relevo

As características, quantitativas e qualitativas, das unidades fisiográficas relativas à rede de drenagem e ao relevo, são apresentadas nas Tabelas 6, 7 e 8, respectivamente para as escalas $1: 25.000 ; 1: 50.000$; e 1:250.000. Para facilitar a apresentação, as características qualitativas da drenagem e do relevo são representadas, nas citadas Tabelas por códigos numéricos empregados no tratamento matemático, descrito no ítem 3.2.8. Análise estatística.

Ao comparar os dados apresentados nas referidas Tabelas e Figuras 13, 14 e 15, pode-se verificar, para as unidades fisiográficas equivalentes nas 3 (três) escalas (observações $22 / 44 / 51 ; 27 / 47 / 53$; e 28/48/54), que as características qualitativas dos padrões de drenagem superficial e as do relevo pouco variaram. Em contrapartida, as características quantitativas dos padrões de drenagem superficial apresentam alterações sem uma tendência definida, isto é, para algumas unidades fisiográficas o valor de um determinado parâmetro de drenagem é maior na escala 1:50.000 que o seu equivalente na escala aproximada 1:25.000, enquanto que para outras unidades ocorre o inverso.

Concordando com VETTORAZZI (1988), a variação nos valores dos parâmetros, de uma escala para outra, é uma consequência, principalmente, das diferenças entre os respectivos traçados das redes de drenagem, no tocante ao número e ao comprimento dos segmentos de rios. 
)

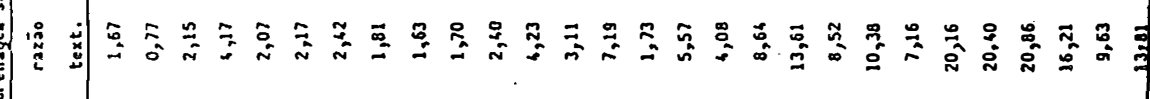
.

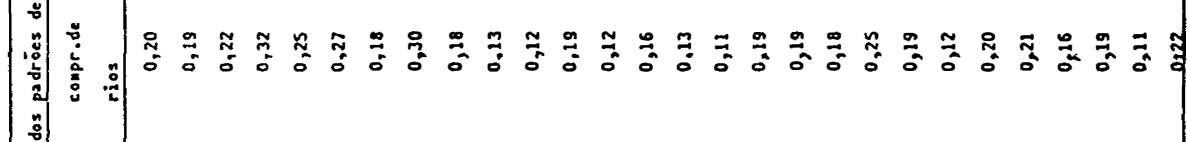

6

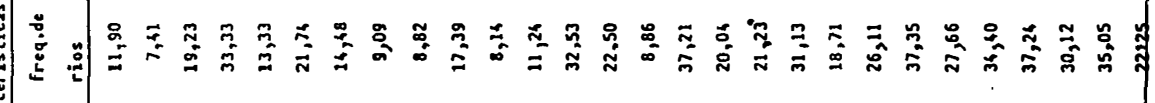

$\frac{\mathscr{d}}{\tilde{T}}$

$\frac{\pi}{\mathbb{\pi}}$ 


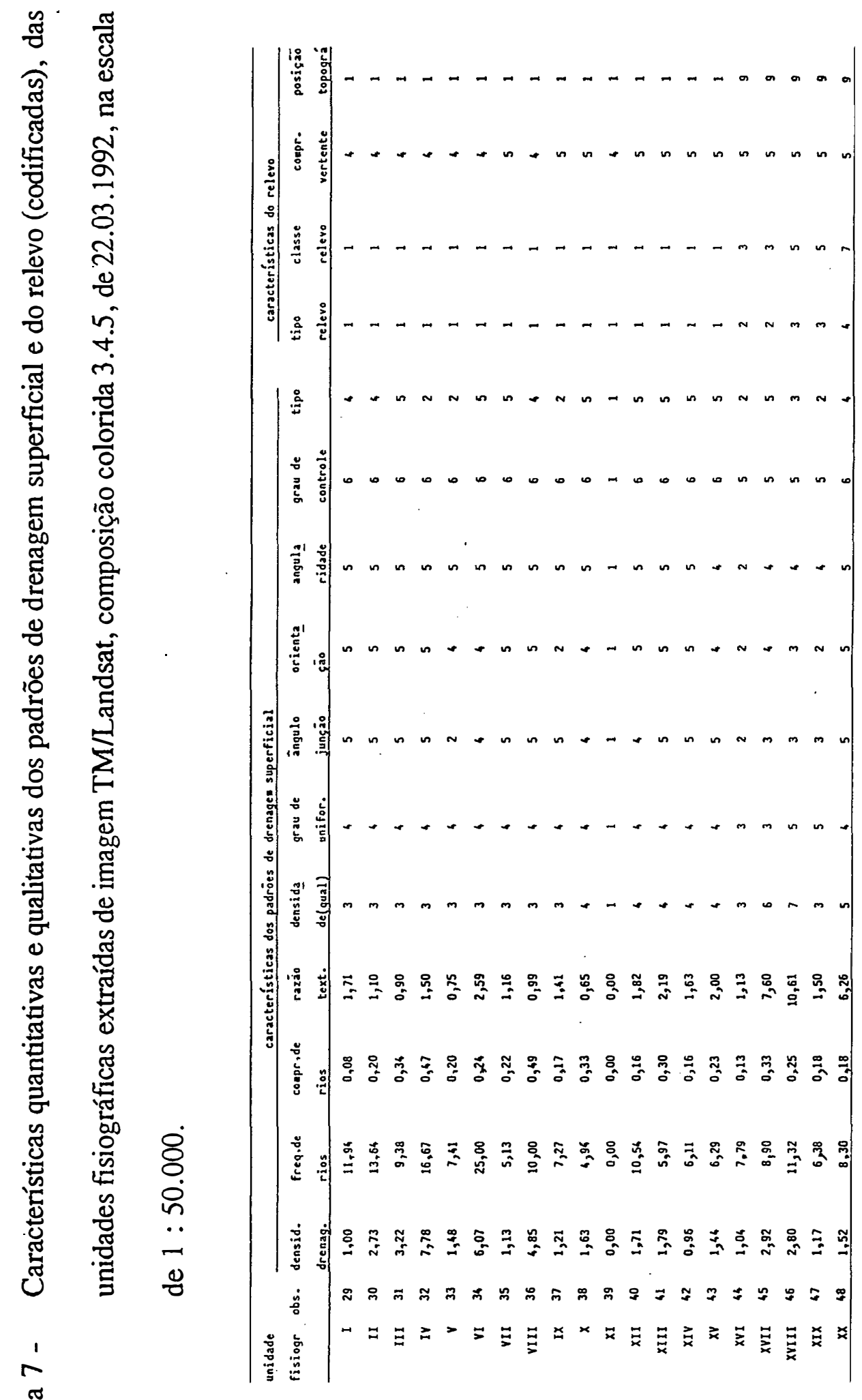




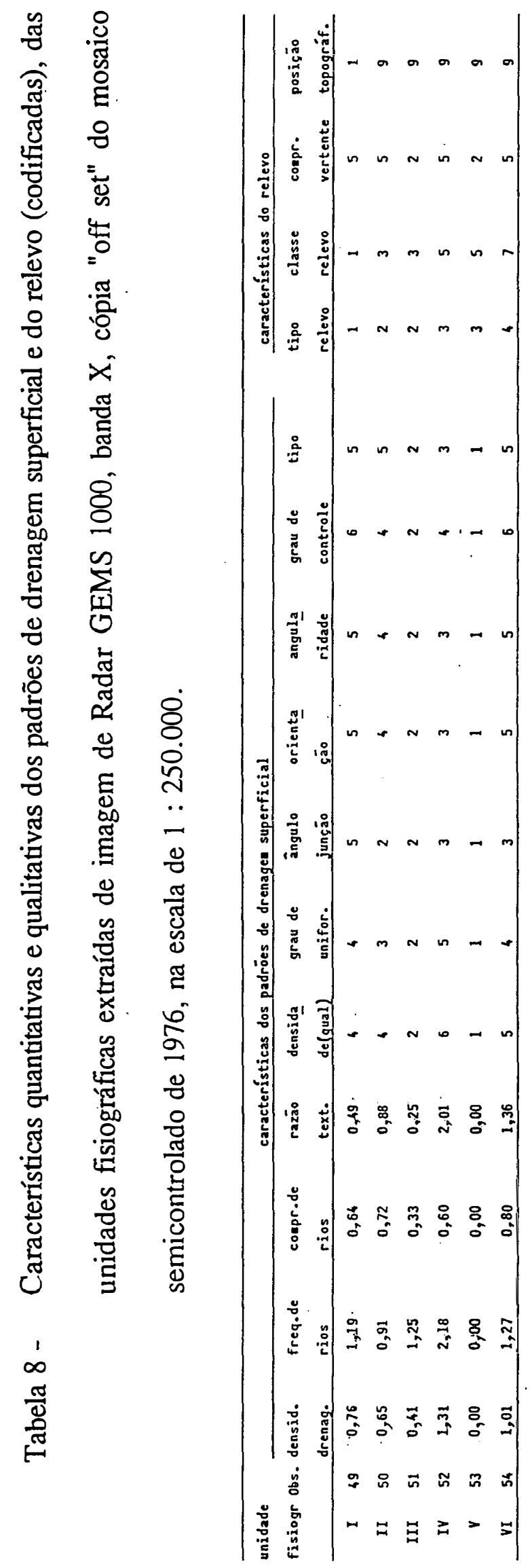


Partindo-se do princípio de que o traçado da rede extraído de fotografias aéreas na escala aproximada de 1:25.000 aproxima-se mais da "verdade terrestre" que o obtido sobre imagem TM/Landsat na escala 1:50.000 e sobre imagem de radar na escala 1:250.000, por motivos inerentes à própria escala, a redução no número dos segmentos de rios e/ou no comprimento dos rios, pode ser considerado um fato normal. O aumento desses valores (número e/ou comprimento de rios), quando se passa da escala 1:250.000, para a 1:50.000, ou para 1:25.000, pode ser atribuído também às deficiências da escala menor, não proporcionando condições para uma interpretação mais detalhada.

No caso específico do delineamento da rede de drenagem, determinadas feições da paisagem, registradas nas imagens de escala muito pequena, podem induzir suas inclusões no traçado da rede como sendo canais de drenagem. Como consequência direta das limitações da escala 1:250.000 é o menor número de unidades fisiográficas delimitadas na imagem de radar (6 unidades) em relação à escala 1:50.000 da imagem TM/Landsat - composição colorida 3,4,5, - (20 unidades) e ainda em relação à escala aproximada de 1:25.000 das fotografias aéreas (28 unidades).

\subsection{Correlação pedológica das unidades fisiográficas}

A Tabela 9 apresenta a relação das unidades fisiográficas, nas 3 (três) escalas estudadas, com os seus respectivos solos. 
Tabela 9 - Correlação pedológica das unidades fisiográficas do P.E. da Ilha do Cardoso, SP.

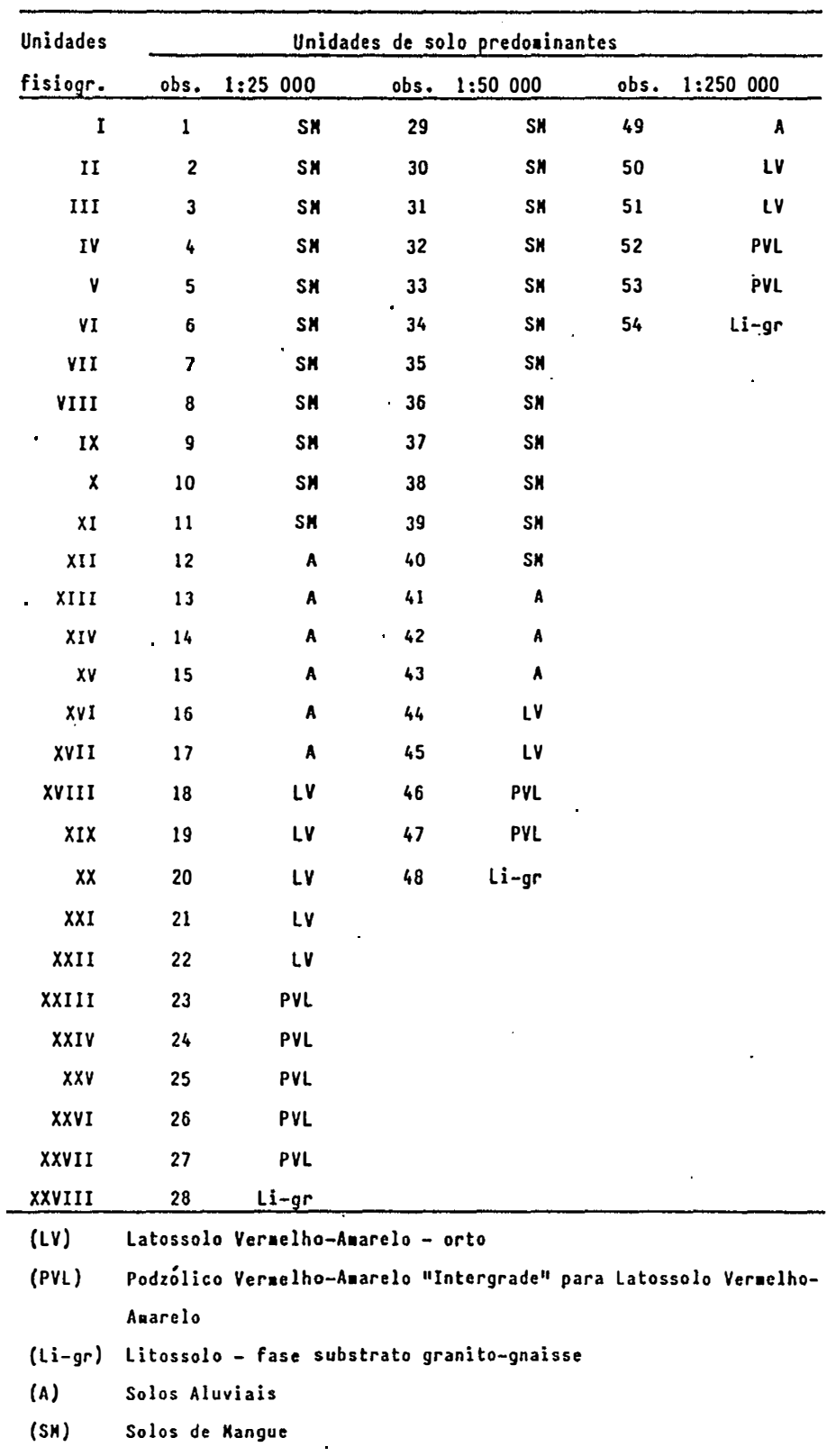


Analisando conjuntamente os dados fornecidos pelas Tabelas 3 a 5 (características dimensionais), Tabelas 6 a 8 (características quantitativas e qualitativas) e Tabela 9 (caracterização pedológica), para as 3 (três) unidades equivalentes, tem-se que:

a) Observações 22/44/51 - Neste caso, o solo predominante é o LV (Latossolo Vermelho-Amarelo-Orto), cuja textura média e estrutura granular do horizonte A permitem uma infiltração das águas pluviais que, atingindo o horizonte B argiloso com estrutura em blocos subangulares, tornam-se responsáveis pela formação de canais (vales). Como o relevo é ondulado, resulta para este tipo de solo um menor número de canais (13 em média) com maior extensão (1,65 km, em média) quando comparado com as características dimensionais da unidade PVL (27/47/53) e constatado pelo exame das Tabelas 3, 4, e 5 . Concordando com PFEIFER (1984), as características do padrão de drenagem da unidade LV apresentam um grau de integração médio, assim como uma média densidade de drenagem que, aliados à orientação de seus canais e ao médio grau de controle, explica sua relação infiltração/deflúvio, enquanto que o relevo e declividade conferem um grau de uniformidade não uniforme, angularidade média e ângulos de junção agudos fechados, cujo tipo ou modelo é subparalelo.

b) Observações 27/47/53 - O. solo predominante nesta unidade fisiográfica é o PVL (Podzólico Vermelho-Amarelo "Intergrade" para Latossolo Vermelho-Amarelo) que, 
apesar de possuir um horizonte B textural, o fato de ser muito profundo e possuir horizonte B com textura mais argilosa, confere à esta unidade, valores intermediários para número de segmentos de rios (14, em média) e menor extensão de canais $(1,58$ $\mathrm{km}$, em média), quando comparada com as outras unidades estudadas e conforme podese verificar nas Tabelas 3, 4 e 5. Concordando com PFEIFER (1984), a unidade PVL apresenta um alto grau de integração e baixa densidade de drenagem. $\mathrm{O}$ tipo ou modelo do padrão é dendrítico, principalmente nas partes mais elevadas do relevo, onde os rios se distribuem sem direção preferencial, refletindo as características do perfil, enquanto que nas partes mais baixas do relevo os rios de ordens mais elevadas apresentam alguma orientação, um certo grau de controle, angularidade moderada e ângulos de junção agudos fechados, possivelmente indicando que estão correndo sobre a rocha. Essas características refletem a presença de um controle litológico que também define a unidade de solo, porque é constituída por um solo "intergrade" que inclui solos profundos a moderadamente profundos (PFEIFER, 1981/82 e PFEIFER \& DOMINGUES, 1983/85).

c) Observações 28/48/54 - Neste caso, o solo predominante é o Li-gr (Litossolo-fase substrato granito-gnaisse) cuja pequena profundidade, capacidade de infiltração e presença de rochas, refletem a sua baixa permeabilidade. Ocorre em relevo montanhoso e possui um maior número de segmentos de rios (137, em média) com maior extensão (33,72 km, em média), quando comparada com as outras unidades e conforme pode-se 
verificar nas Tabelas 3, 4 e 5. Essas características proporcionam à unidade Li-gr, uma relação infiltração/deflúvio menor. Concordando com PFEIFER (1984), a unidade Li-gr do P.E. da Ilha do Cardoso apresenta um grau de integração médio e média densidade de drenagem (qualitativa), refletindo sua alta relação infiltração/deflúvio que, associados à declividade e permeabilidade, conferem um tipo ou modelo de drenagem retangular pouco uniforme. O padrão de drenagem é orientado, apresentando alto grau de controle, alta angularidade com ângulos de junção retos, ocasionalmente agudos. Essas características associadas ao tipo e extensão dos rios, levam a crer que a rede de drenagem dessa unidade de solo está sujeita a um controle estrutural, o que concorda com as observações de PFEIFER (1981/82 e 1984) e PFEIFER \& DOMINGUES (1983/85). Além disso, com a diminuição da profundidade do perfil e pela própria posição no relevo, os rios sofrem um controle estrutural da rocha subjacente que apresenta diáclases longitudinais, as quais determinam a direção preferencial e extensão dos segmentos de rios de $2^{\mathfrak{a}}$ e $3^{\mathfrak{a}}$ ordens, o que também concorda com as observações feitas por PARVIS (1950) e LUEDER (1959).

Nota-se ainda que pelas aerofotografias (1:25.000) é possível delinear 28 unidades fisiográficas, das quais 11 se referem aos Solos de Mangue (SM), 6 aos Solos Aluviais (A), 5 aos Latossolos Vermelho-Amarelo-orto (LV), 5 aos Podzólicos Vermelho-Amarelo "intergrade" para Latossolo Vermelho-Amarelo (PVL) e um aos Litossolos-fase substrato granito-gnaisse ( $\mathrm{Li}$-gr); pela imagem TM/Landsat (1:50.000) detecta-se 20 unidades, sendo 12 com SM, 3 com A, 2 com LV, 2 com PVL e 1 com 
Li-gr; e pelo mosaico semicontrolado de radar, obtem-se apenas 6 unidades fisiográficas das quais uma refere-se a A, 2 a LV, 2 a PVL e 1 a Li-gr.

Alguns autores, estudando os parâmetros, densidade de drenagem (Dd), frequência de rios (Fr) e razão de textura (T) das redes de drenagem, relacionando-os com os materiais subjacentes (rochas ou solos), obtiveram conclusões muito generalizadas sobre os fatores responsáveis pelo desenvolvimento das redes, tais como: permeabilidade e resistência à erosão, e relação infiltração/deflúvio. Como argumenta CARVALHO (1977 e 1981), o fato desses autores terem trabalhado com bacias hidrográficas de elevadas ordens de ramificação, possivelmente com a inclusão de outros materiais (rochas ou solos), leva a crer que essa seja a razão de seus resultados não terem sido tão consistentes.

Concordando com PFEIFER (1984) e observando-se as Tabelas 6, 7 e 8, pode-se constatar que os parâmetros estudados fornecem índices que mostram uma diferenciação entre as unidades LV, PVL e Li-gr.

Assim sendo, a densidade de drenagem resulta para a unidade LV num valor médio de 2,02; para a PVL, 1,64 e para a unidade Li-gr um valor médio de 2,50, devido aos processos de formação. Concordando com HORTON (1945) a unidade Li-gr, por possuir maior densidade de drenagem, é uma unidade mais susceptível à erosão.

A frequência de rios, relacionando o número total de segmentos de rios com a respectiva área, mostra-se um dado consistente, evidenciando uma real diferença 
entre as três unidades, isto é, resulta para a unidade LV num valor médio de 15,46 ; para a PVL, 13,81 e para a unidade Li-gr um valor médio de 10,61.

Os valores médios obtidos para a razão de textura mostram uma boa diferenciação entre a unidade Li-gr e as outras unidades estudadas. O valor da razão de textura média para a unidade $\mathrm{Li}$-gr é de 7,14 , o que permite classificá-la como pertencente à classe textural topográfica fina (FRANÇA, 1968); para a unidade LV um valor de razão de textura média igual a 2,85 , o que a classifica como pertencente à classe de textura topográfica média e para a unidade PVL um valor de razão de textura média igual a 3,71, o que a classifica também como pertencente à classe de textura topográfica média.

Portanto, pode-se dizer que as características quantitativas e qualitativas dos padrões de drenagem superficial e do relevo são bons parâmetros para a diferenciação entre solos morfogeneticamente distintos e que as unidades fisiográficas mostram-se eficientes como sistema de amostragem, para o P.E. da Ilha do Cardoso, com vantagens sobre outros sistemas - bacias hidrográficas de $3^{\mathrm{a}}$ ordem de ramificação e amostras circulares de $10 \mathrm{~km}^{2}$ de área, utilizadas por PFEIFER (1984) - visto que os parâmetros estudados em unidades fisiográficas fornecem índices que mostram uma diferenciação entre as unidades LV, PVL e Li-gr, indicando uma relativa proximidade para LV e PVL, como era de se esperar, pois o PVL trata-se de um solo "intergrade", isto é, num grau intermediário entre Podzólico Vermelho-Amarelo e Latossolo Vermelho-Amarelo. 


\subsection{Análise de agrupamentos}

A premissa básica do presente estudo é de analisar, quantitativamente e qualitativamente, alguns parâmetros da rede de drenagem e do relevo com vistas à caracterização das diferenças entre solos, fotointerpretadas em fotografias aéreas na escala aproximada de 1:25.000, em imagem TM/Landsat - composição colorida 3,4,5 na escala 1:50.000, e em imagem de radar na escala 1:250.000.

Para verificar a ação conjunta e a classificação por ordem de importância dos parâmetros estudados, é aplicado a Análise de Agrupamento (SAS, 1987) para as unidades fisiográficas mapeadas nos 3 (três) produtos de sensores remotos e respectivas escalas.

\subsubsection{Fotografias aéreas na escala aproximada de 1:25.000}

O diagrama obtido a partir da Análise de Agrupamentos para as unidades fisiográficas (amostras) relativas à interpretação das aerofotografias na escala aproximada de 1:25.000, é apresentado na Figura 16.

Pela análise desse diagrama, observa-se que um grupo de amostras destaca-se facilmente das demais (a um valor maior que 1,2 para o coeficiente de semelhança) sendo formado pelas unidades: $1 ; 5 ; 7 ; 12 ; 2 ; 8 ; 9 ; 15 ; 11 ; 3 ; 17 ; 10 ; 6$; e 14, denominado de GR1. 


\section{"Average Linkage Cluster Analysis" \\ Nome da Observacao ou "Cluster"}

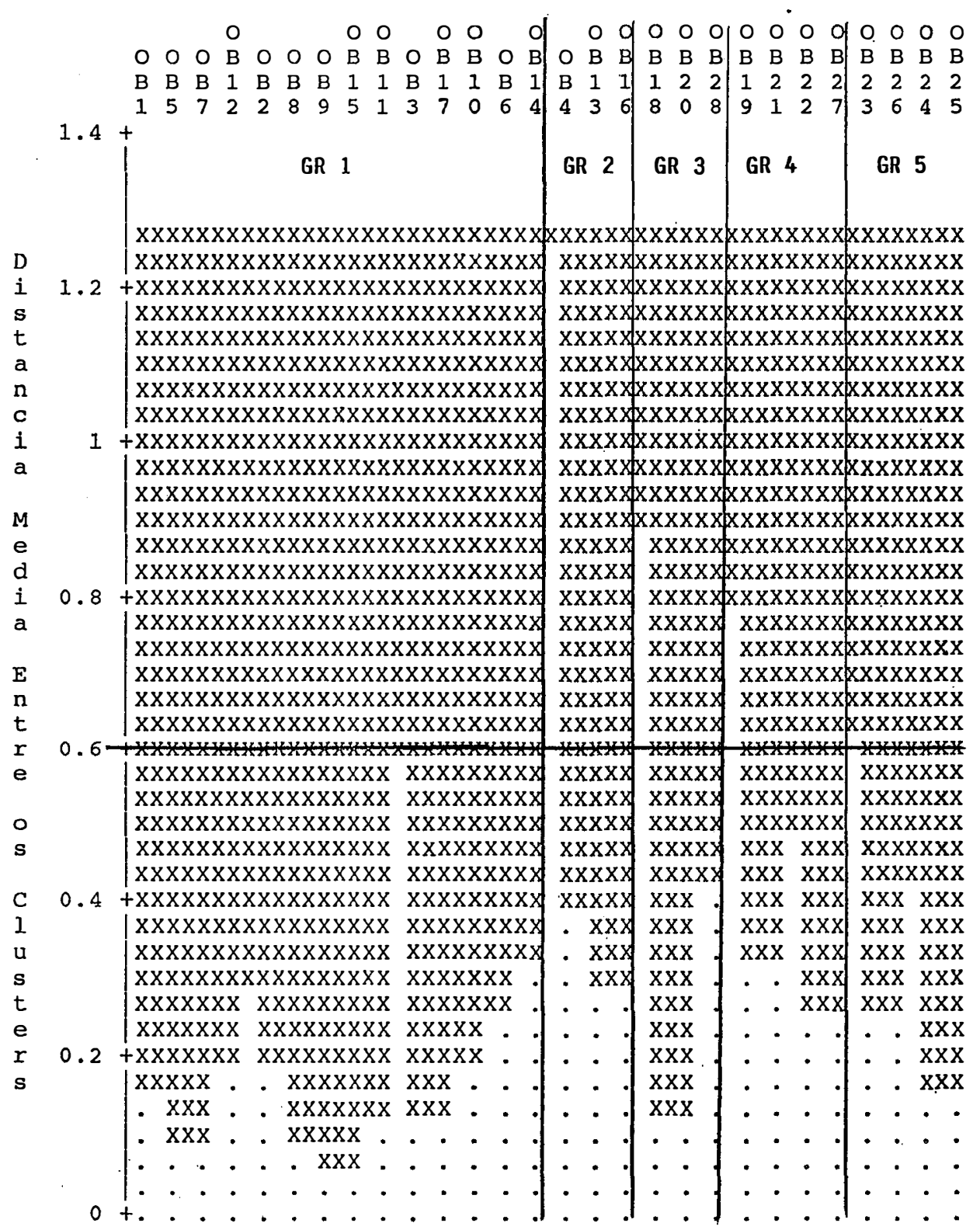

GR $1(S H, A) ; \operatorname{GR} 2(S K, A) ; \operatorname{GR~} 3(L V, L i-g r) ; \operatorname{GR} 4$ (LV, PVL); e, GR 5 (PVL).

Figura 16 - Dendrograma da Análise de Agrupamentos dos padrões de drenagem

superficial, extraídos das aerofotografias na escala

aproximada 
Ao recorrer à Tabela 9, pode-se notar que a maioria das unidades fisiográficas do GR1 possuem como solos predominantes os Solos de Mangue, à exceção das unidades 12, 15, 17 e 14 com solos Aluviais, cuja inclusão em GR 1, muito provavelmente tenha sido em decorrência da posição do relevo que ocupam (tiposubnormal e classe-plano).

Concordando com PFEIFER (1981/82), os Solos de Mangue (SM) são constituídos por solos de várzea, pouco profundos, com características associadas, com encharcamento, redundando em acumulação de matéria orgânica na camada superficial, sendo desenvolvido a partir de sedimentos aluviais, de origem fluvial e marinha, provenientes da decomposição das rochas, transportados e depositados. Os Solos Aluviais (A) são provenientes de material não consolidado, de deposição recente, apresentando-se em camadas estratificadas, sem relação genética entre si, isto é, são constituídos de sedimentos aluviais que formam camadas estratificadas compostas de materiais argilosos, arenosos ou siltosos, dispostos uns sobre os outros, não havendo sequência preferencial na superposição.

Continuando a observação da Figura 16, nota-se que a um valor próximo a 0,8 para o coeficiente de semelhança, isto é, da distância média entre os "clusters", um outro grupo pode ser isolado. Este novo grupo (GR2) é constituído pelas unidades: 4,13 e 16.

Nota-se, ao se recorrer à Tabela 9 , que os solos predominantes nessas unidades são os mesmos descritos anteriormente, isto é, Solos de Mangue (observação 
4) e Solos Aluviais (observações 13 e 16). O isolamento desse grupo (GR2) deve ter sido em virtude de possuírem um índice de frequência de rios semelhantes, que relaciona o número total de segmentos de rios com a respectiva área da unidade fisiográfica (Tabela 6).

Sendo excluídas as unidades fisiográficas dos grupos GR1 e GR2, as demais formam um grupo relativamente heterogêneo, onde a predominância numérica é para as amostras com solos mais evoluídos e na grande maioria, localizados no maciço rochoso do P.E. da Ilha do Cardoso. Tais amostras, ou unidades fisiográficas, podem ser isoladas a um valor da distância média entre os "clusters" próximo de 0,6 do diagrama (Figura 16).

Fazem parte do grupo GR3 as unidades fisiográficas 18,20 e 28, constituídas por Latossolos (unidades 18 e 20) e Litossolos (unidade 28). O isolamento desse grupo (GR3) deve ter sido por possuir um índice de densidade de rios semelhantes, que relaciona o comprimento total de segmentos de rios com a respectiva área da unidade fisiográfica (Tabela 6). A análise de agrupamentos está em acordo com as observações de PFEIFER (1984) que aproximam também as duas unidades taxonômicas. Concordando com PFEIFER (1981/82), o Latossolo Vermelho-AmareloOrto (LV) é constituído de solos argilosos, profundos, de coloração alaranjada, ácidos e com saturação por bases baixa; são solos bem drenados, com horizonte B latossólico e ocupam as meias encostas e patamares de morros cristalinos, sendo que no sopé e na meia encosta, apresentam relevo ondulado a montanhoso e são formados a partir de 
rochas granito-gnaisse. O Litossolo-fase substrato granito-gnaisse (Li-gr) apresenta como principal característica a pequena espessura do "solum", a qual em geral é um torno de $40 \mathrm{~cm}$ e sequência de horizontes $\mathrm{A}_{1}-\mathrm{R}$, sendo que a rocha subjacente, em geral, apresenta-se alterada; estes solos ocupam as partes mais acidentadas do P.E. da Ilha do Cardoso, apresentando-se num relevo montanhoso, com várias exposições rochosas e resultam do entalhamento posterior da superfície mais antiga dos solos com B latossólicos.

As unidades fisiográficas de GR4 são caracterizadas pela presença dominante de solos com B latossólico, fazendo parte desse grupo as unidades 19, 21, 22 e 27. As três primeiras unidades com Latossolo Vermelho-Amarelo-Orto (LV) e a unidade 27 com Podzólico Vermelho-Amarelo "intergrade" para Latossol Vermelho-Amarelo (PVL). A inclusão da amostra 27 nesse grupo, provavelmente, deve-se ao fato de ser constituída por um solo "intergrade", cujas características refletem a presença de um controle litológico, o que concorda com CARVALHO (1981) e PFEIFER (1981/82).

Ainda observando o diagrama da Figura 16, nota-se que a Análise de Agrupamentos isola um último grupo - GR5 - a um valor de distância média entre os "clusters" de 0,6.

Esse grupo (GR5) é constituído pelas unidades fisiográficas 23, 26, 24 e 25, todas com Solo Podzólico Vermelho-Amarelo "intergrade" para Latossolo Vermelho-Amarelo (PVL) que corroborando com BRASIL - SNPA (1960) e PFEIFER (1981/82), apresenta característica morfológica mais comum ao Podzólico VermelhoAmarelo-Orto, isto é, com horizonte B textural, estrutura em blocos subangulares e presença de cerosidade nas superfícies dos elementos estruturais. 
A caracterização em termos quantitativos dos padrões de drenagem superficial, isto é, a estatística descritivas das variáveis contínuas, elaborada com base na interpretação de fotografias aéreas, do vôo de recobrimento do Estado de 1972, na escala aproximada de 1:25.000, é apresentada na Tabela 10.

Observando a referida Tabela, nota-se que o coeficiente de variação (CV) separa nítidamente as amostras em 2 (dois) subgrupos. Um constituído pelos GR1 e GR2, isto é, formados pelas unidades fisiográficas com Solos de Mangue e Aluviais (numa mesma posição topográfica) e outro, constituído pelos GR3, GR4 e GR5 com unidades fisiográficas localizadas no maciço rochoso e com solos mais evoluídos. Podese extrair também que dentro desse segundo subgrupo, o coeficiente de variação do GR5 apresenta-se mais homogêneo, o que era de se esperar, pois é o único grupo formado por unidades fisiográficas constituídas com uma única unidade taxonômica, isto é, com o Solo Podzólico Vermelho-Amarelo "intergrade" para Latossolo VermelhoAmarelo (PVL). Portanto, a separabilidade dos 5 (cinco) grupos proporcionadas pela Análise de Agrupamento, é plenamente justificada pelo dendrograma apresentado na Figura 16.

\subsubsection{Imagem TM/Landsat - composição colorida 3,4,5 - na escala 1:50.000}

O dendrograma obtido a partir da Análise de Agrupamento para as unidades fisiográficas (amostras) relativas à interpretação da imagem de satélite na escala 1:50.000, é apresentado na Figura 17. 
จิ

กิำำ

政

จิ๊

ㄴ.?ㄴ.?

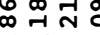

제융

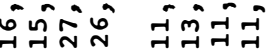

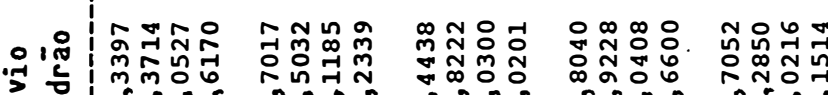

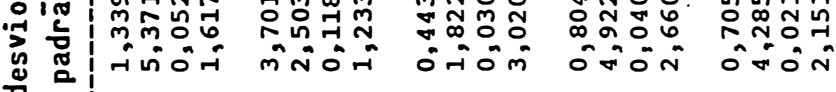

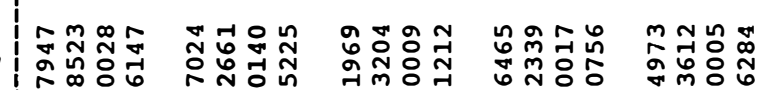

क तं

8

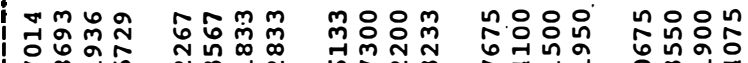

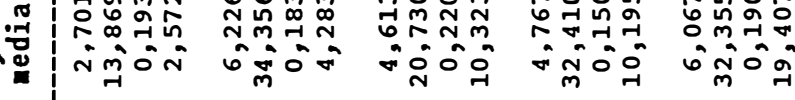

요 8

ษัว

ช্

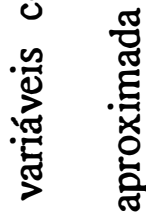

ช

.

ชี

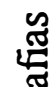

త్ర దूద

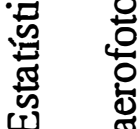

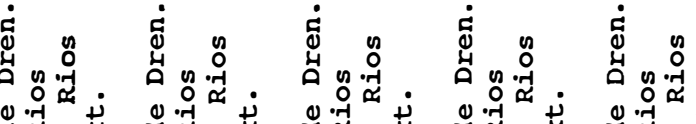

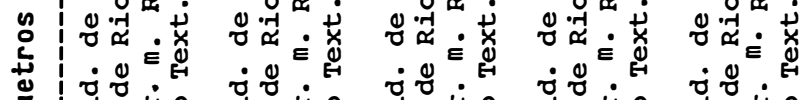

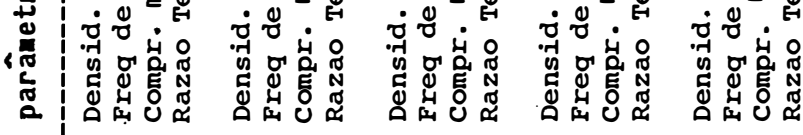

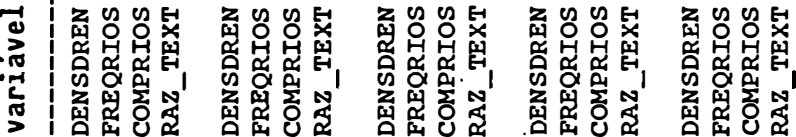

今ี

m

m

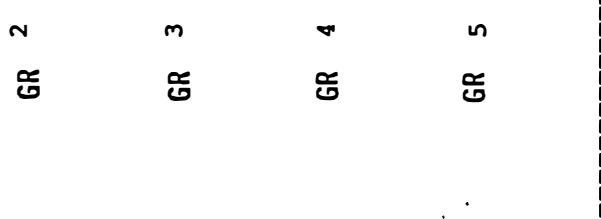

$\frac{1}{\frac{0}{0}}$ 


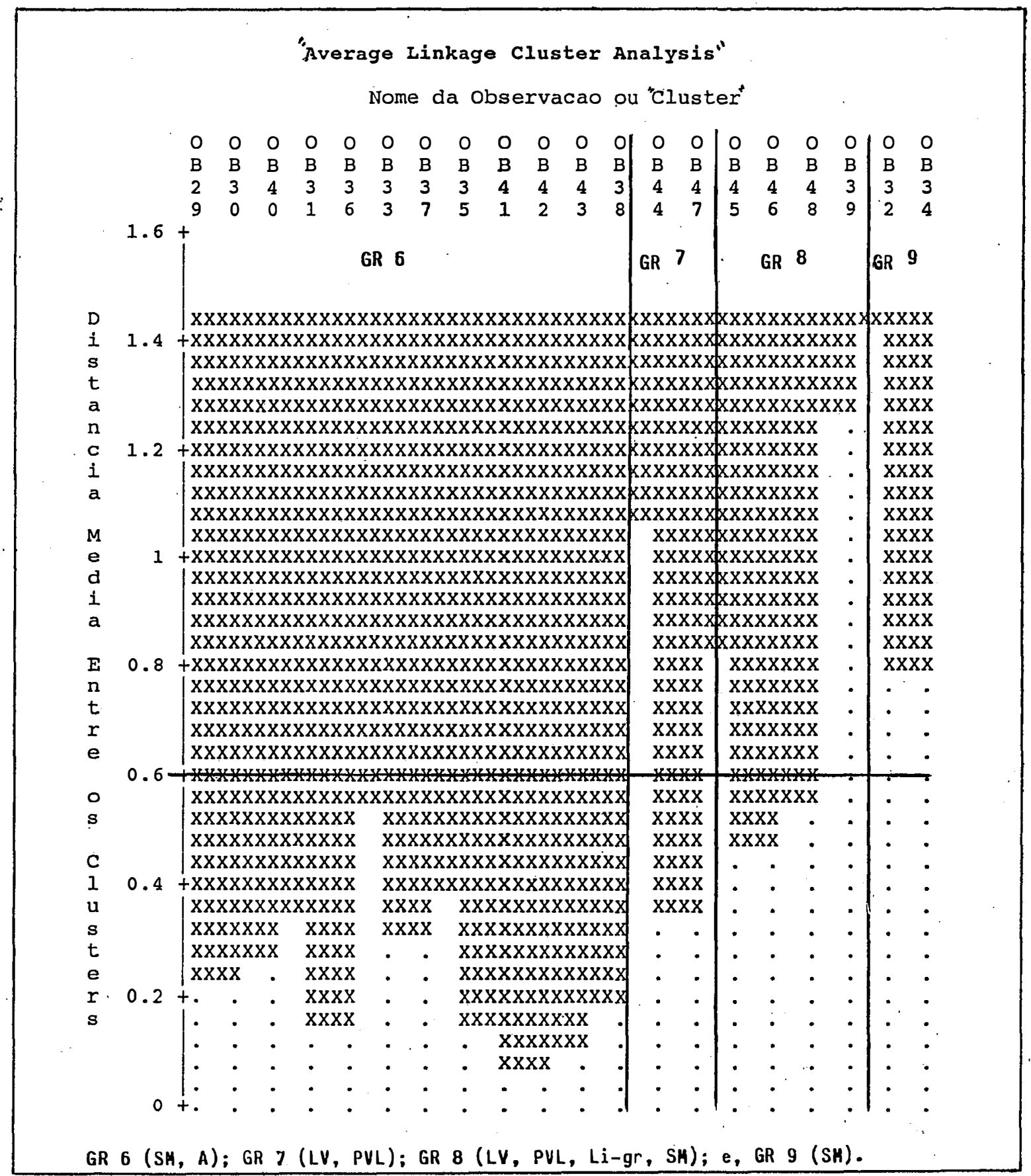

Figura 17 - Dendrograma da Análise de Agrupamentos dos padrōes de drenagem superficial, extraídos da imagem TM/Landsat - composição colorida 3, 4,5 , na escala de $1: 50.000$ 
Observando diretamente o ponto 0,6 da distância média entre os "clusters" do dendrograma (Figura 17), nota-se o isolamento de 4(quatro) grupos:

GR 6 constituído pelas unidades $20,30,40,31,36,33,37,35,41,42,43$ e 38 ;

GR 7 constituído pelas unidades 44 e 47;

GR 8 constituído pelas unidades 45, 46, 48 e 39; e

GR 9 constituído pelas unidades 32 e 34 .

Confrontando-se o isolamento desses grupos com a Tabela 9, pode-se notar que as unidades fisiográficas do GR 6 possuem como solos predominantes os Solos de Mangue à exceção das unidades 41, 42 e 43, que possuem Solos Aluviais; o GR 7 que possuem os Latossolo Vermelho-Amarelo-Orto e Podzólico VermelhoAmarelo "intergrade" para Latossolo Vermelho-Amarelo; o GR 8 que detêm todas as unidades taxonômicas (LV + PVL + Li-gr + SM), com exceção dos Aluviais; e o GR 9, no qual há ocorrência dos Solos de Mangue.

Portanto, o agrupamento mais significante é dado pelo GR 7 que isola unidades fisiográficas ocorrentes em solos com B latossólico e B textural, isto é, com solos mais desenvolvidos.

A caracterização em termos quantitativos dos padrões de drenagem superficial, ou seja, a estatística descritiva das variáveis contínuas, elaborada com base na interpretação da imagem de satélite na escala 1:50.000, é apresentada na Tabela 11. 


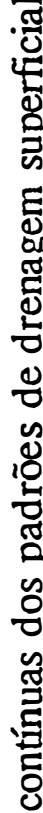

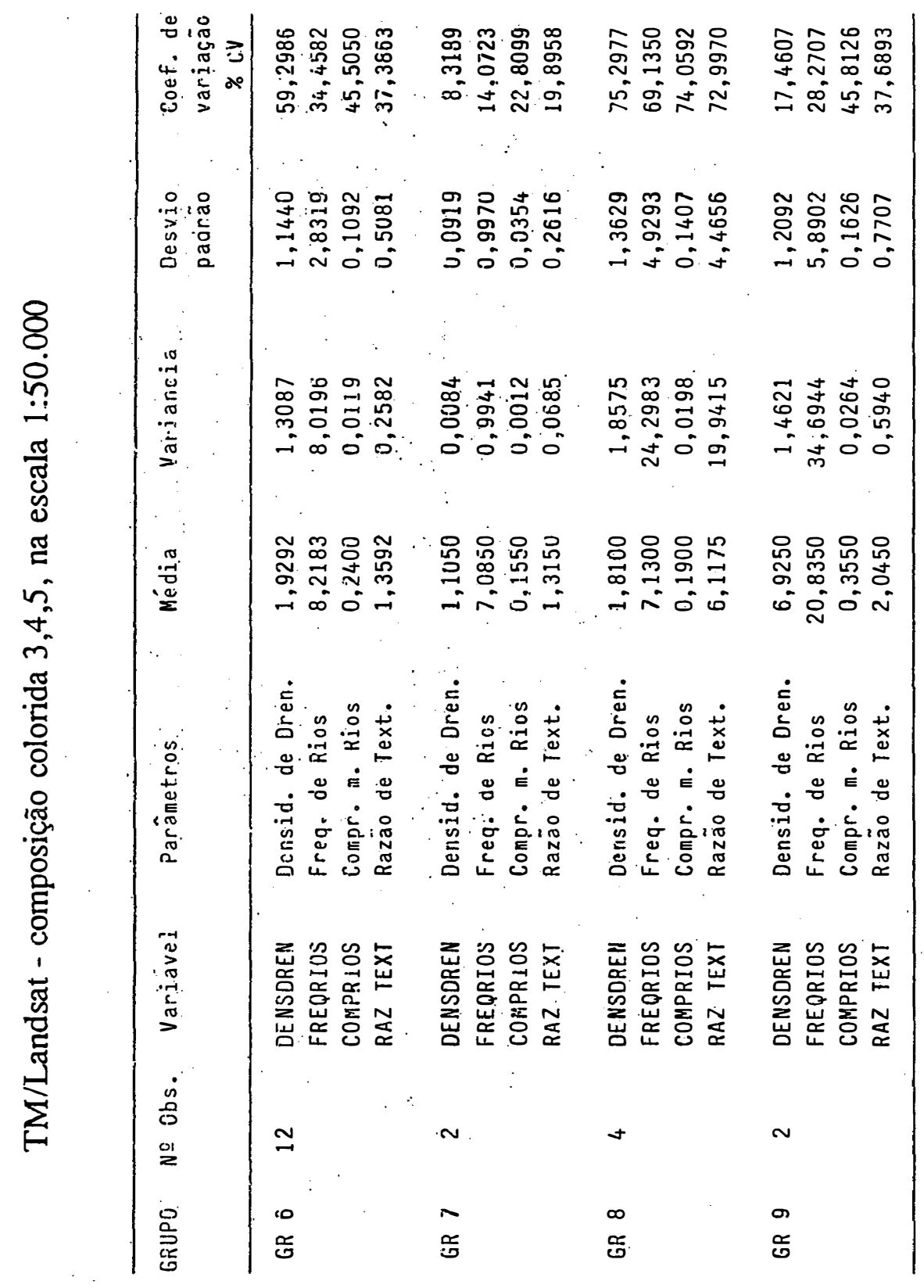


Comparando-se os coeficientes de variação dos parâmetros da rede de drenagem das unidades fisiográficas, ou seja, densidade de drenagem, frequência de rios, comprimento médio de rios e razão de textura, de todos os grupos isolados, notase que os melhores resultados são os pertencentes ao GR 7, com coeficientes de variação mais baixos.

Comparando-se também os dados fornecidos pelas Tabelas 10 e 11, notase que os resultados obtidos pela interpretação das fotografias aéreas, são mais consistentes. Portanto, observa-se que para o nível do mapeamento de solos correlacionado, as fotografias aéreas na escala aproximada de 1:25.000, fornecem resultados mais consistentes que os resultados da interpretação da imagem TM/Landsat composição colorida 3,4,5 - na escala 1:50.000, para o caso da análise quantitativa dos padrões de drenagem superficial, na diferenciação entre solos, o que concorda com VALÉRIO FILHO (1984).

\subsubsection{Imagem de radar GEMS 1000, banda X, cópia "off set", na escala de 1:250.000}

O dendrograma obtido a partir da Análise de Agrupamentos para as unidades fisiográficas (amostras) relativas à interpretação da imagem de radar na escala 1:250.000, é apresentado na Figura 18. 


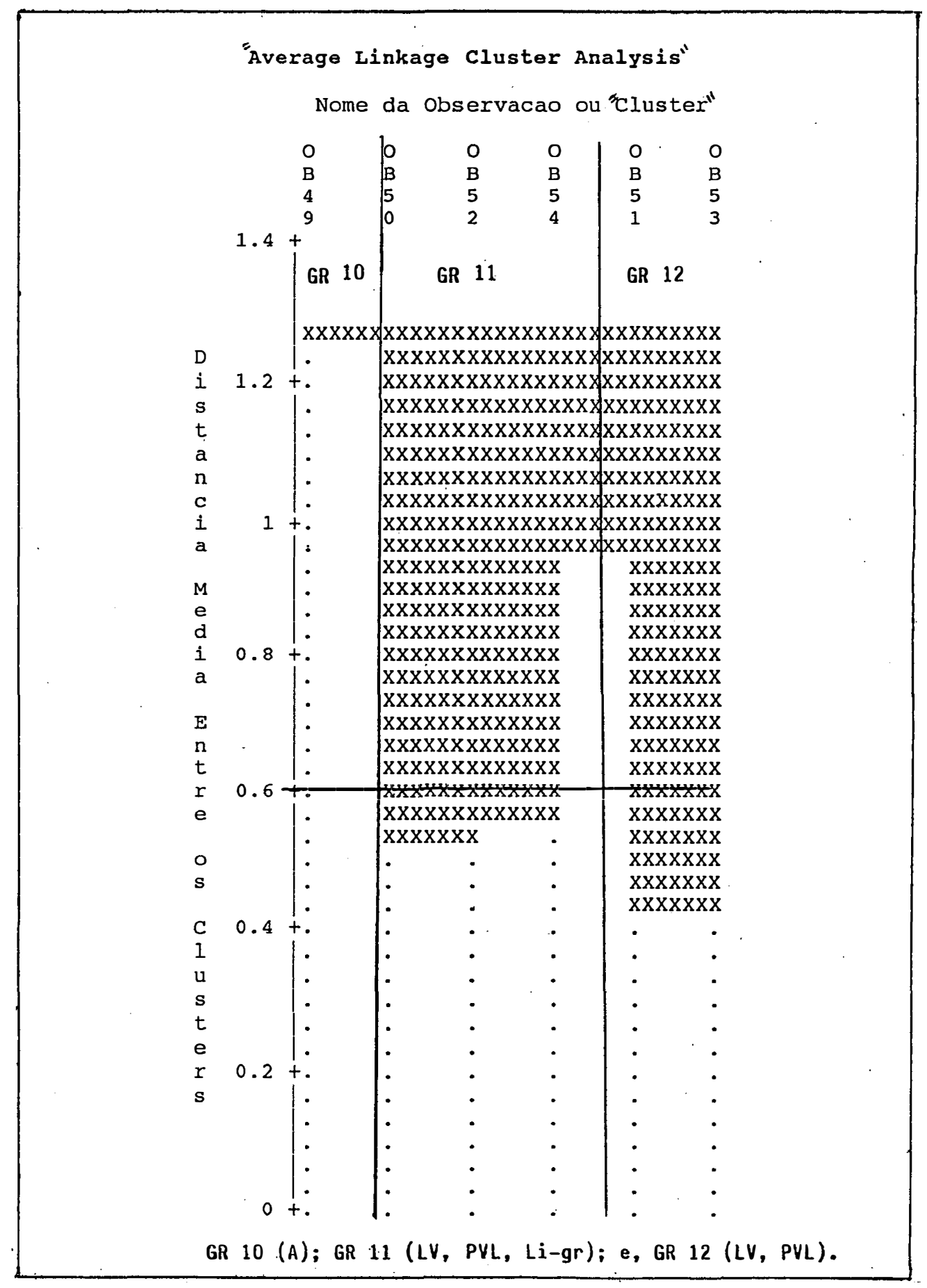

Figura 18 - Dendrograma da Análise de Agrupamentos dos padrões de drenagem superficial, extraídos da imagem de radar GEMS 1000, banda X, cópia "off set", na escala de 1:250.000. 
Como se esperava, a Análise de Agrupamentos detecta apenas 3(três) grupos, devido a própria deficiência de interpretação das unidades fisiográficas nessa escala (em número de 6 unidades).

Pela análise do diagrama, observa-se que um grupo de amostras destaca-se facilmente das demais (a um valor maior que 1,2 para a distância média entre os "clusters"), sendo formado pela unidade 49, denominado de GR 10.

Ao se recorrer à Tabela 9, nota-se que a unidade fisiográfica (49) do GR 10 possui solos Aluviais. Devido a problemas de interpretação de imagens de pequena escala, os Solos de Mangue não são detectados, isto é, são englobados na classe dos Aluviais por serem mais predominantes.

Logo abaixo do ponto 1,0 da distância média entre os "clusters", nota-se o isolamento de outro grupo (GR 11), do qual fazem parte as unidades 50, 52 e 54. Reportando-se à Tabela 9 e Figura 15, observa-se que, respectivamente, essas unidades possuem solos LV, PVL e Li-gr, todos do maciço rochoso do P.E. da Ilha do Cardoso. O último grupo isolado pela Análise de Agrupamentos pode ser observado no ponto 0,6 da distância média entre os "clusters" (Figura 18), o GR 12, do qual fazem parte as amostras 51 e 53. Tais amostras possuem respectivamente solos LV e PVL (Tabela 9 e Figura 15), oriundas das unidades fisiográficas dos 2(dois) morrotes do Parque.

Comparando-se os 3 (três) dendrogramas (Figuras 16, 17 e 18), observase que os grupos - GR 4, GR 7 e GR 12 - são equivalentes, isto é, aś unidades 
(observações) 22/27; 44/47; e 51/53, referentes aos morrotes isolados de P.E. da Ilha do Cardoso, com solos LV e PVL respectivamente, são passíveis de delineamento na interpretação dos diversos produtos de sensores remotos (aerofotografias, imagens de satélite e de radar) e consequentemente nas 3 (três) escalas estudadas (1:25.000, 1:50.000 e 1:250.000), o que proporciona o isolamento dos referidos grupos pela Análise de Agrupamentos.

A Tabela 12, apresenta a caracterização quantitativa dos padrões de drenagem superficial, isto é, a estatística descritiva das variáveis contínuas, elaboradas com base na interpretação da imagem de radar, na escala de 1:250.000.

Nota-se que para o GR 10, não é possível o cálculo do coeficiente de variação devido, ter esse grupo, apenas uma observação, isto é, apenas uma unidade fisiográfica (49).

Observa-se também que os coeficientes de variação do GR 11, com 3 (três) observações, ou seja, referentes às unidades 50, 52 e 54 são tão mais altos que os calculados para a interpretação da imagem de satélite (Tabela 11).

Ainda com relação a Tabela 12 , pode-se notar que o GR 12 possui coeficientes de variação também altos. Neste caso, tal resultado é devido à inclusão da unidade 51 (com apenas um segmento de rio delineado) e da unidade 53 (sem qualquer segmento de rio). 


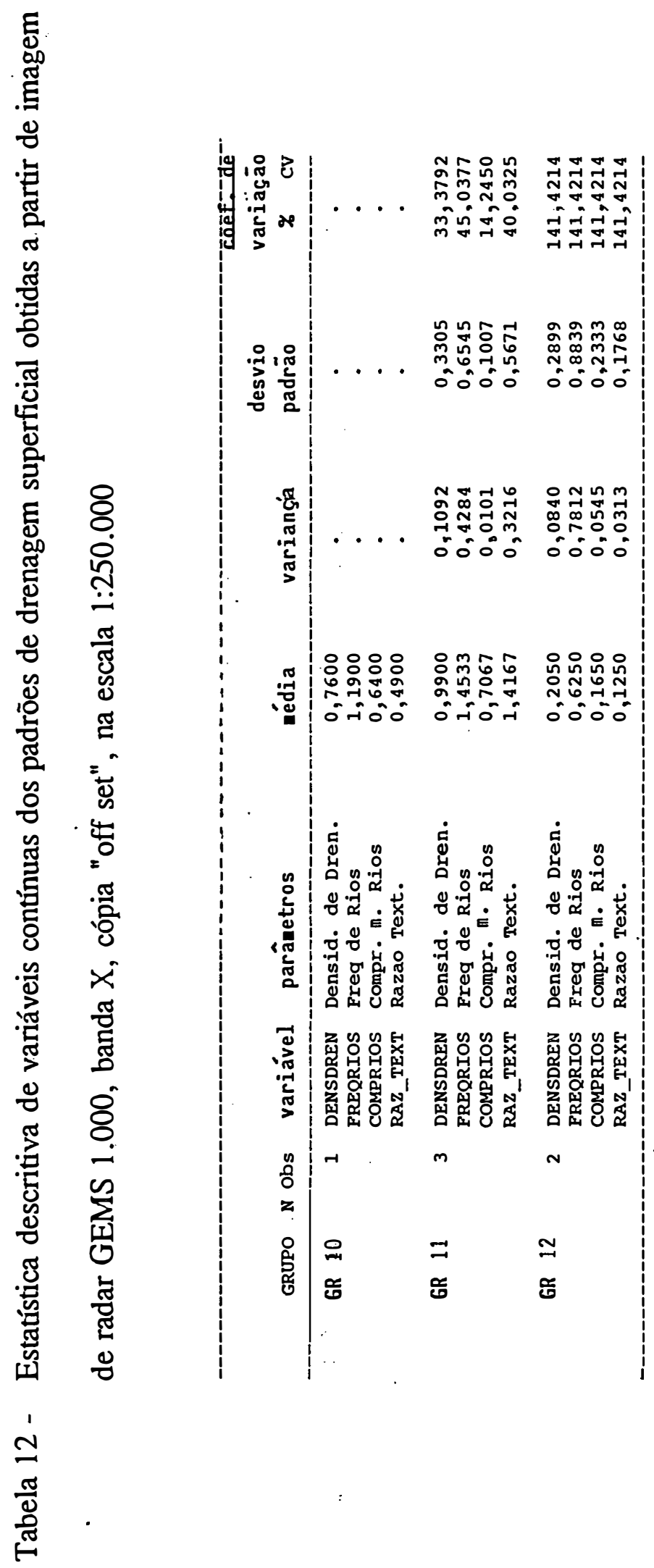


Portanto, comparando-se os resultados apresentados nas Tabelas 10, 11 e 12 , pode-se dizer que a interpretação quantitativa dos padrões da rede de drenagem superficial, do P.E. da Ilha do Cardoso, extraídas das fotografias aéreas (1:25.000) é mais consistente que a extraída da imagem de satélite (1:50.000), e que da interpretada na imagem de radar (1:250.000), isto é, comparando-se a eficiência da interpretação dos diversos produtos de sensores remotos, referente à diferenciação entre solos ao nível de semidetalhe, pode-se estabelecer a seguinte relação:

Aerofotografias $(1: 25.000) \rightarrow$ TM/Landsat $(1: 50.000) \rightarrow$ Radar $(1: 250.000)$

4.7. Avaliação da eficiência dos elementos de interpretação da rede de drenagem superficial

A eficiência em função do número de agrupamentos da maior ou menor contribuição de cada um dos elementos quantitativos da drenagem superficial, na discriminação entre os grupos de unidades fisiográficas, é verificada através de uma análise de variância (Teste F).

Através dos resultados do Teste F, apresentados na Tabela 13, constata-se que: 
Tabela 13 - Resultados do Teste $F$ para as variáveis quantitativas da rede de drenagem superficial dos grupos (GR) definidos a partir de sensores remoto e respectivas escalas.

\begin{tabular}{|c|c|c|c|c|c|}
\hline $\begin{array}{l}\text { Produto de } \\
\text { sensor remoto }\end{array}$ & $\begin{array}{l}\text { Variável } \\
\text { dependente }\end{array}$ & $G L$ & $\begin{array}{l}\text { Q. R. } \\
\text { trat. }\end{array}$ & $F$ & c. $v$. \\
\hline & dens. de dren. & 27 & 0,51 & $6,21 * *$ & 37,93 \\
\hline Aerofotografia & freq. de rios & 27 & 0,81 & $24,79 * *$ & 21,56 \\
\hline \multirow{3}{*}{$(1: 25000)$} & compr. Mo rios & 27 & 0,11 & $0,74 \mathrm{~ns}$ & 29,75 \\
\hline & raz. de text. & 27 & 0,91 . & $62,73^{* *}$ & 27,99 \\
\hline & dens. de dren. & 19 & 0,69 & $12,00 * *$ & 49,84 \\
\hline TH/LAKDSAT & freq. de rios & 19 & 0,61 & $8,36^{* *}$ & 38,33 \\
\hline \multirow[t]{2}{*}{$(1: 50000)$} & compr. n. rios & 19 & 0,18 & $1,22 \mathrm{~ns}$ & 50,13 \\
\hline & raz. de text. & 19 & 0,52 & $5,97 * *$ & 83,76 \\
\hline$:$ & dens. de dren. & 5 & 0,71 & $3,70 \mathrm{~ns}$ & 46,01 \\
\hline Radar & freq. de rios & 5 & 0,33 & $0,76 \mathrm{~ns}$ & 65,20 \\
\hline \multirow[t]{2}{*}{$(1: 250000)$} & compr. m. rios & 5 & 0,83 & $7,44 \mathrm{~ns}$ & 30,64 \\
\hline & raz. de text. & 5 & 0,76 & $4,76 \mathrm{~ns}$ & 57,01 \\
\hline
\end{tabular}

* significativo ao nível de $1 \%$

* significativo ao nível de $5 \%$

ns näo significativo 
a) Todas as variáveis estudadas, tanto em unidades fisiográficas extraídas de fotografias aéreas (na escala aproximada de 1:25.000), quanto de imagem de satélite (na escala de 1:50.000), ocorrem com uma significância ao nível de $5 \%$ de probabilidade, à exceção da variável comprimento médio de rios. Esse fato demonstra que os parâmetros densidade de drenagem, frequência de rios e razão de textura, são capazes de acusar diferenças estatísticas significativas, entre pelo menos, dois dos cinco grupos formados a partir da utilização de aerofotografias e/ou imagem TM/Landsat.

b) Os coeficientes de variação encontrados, para a frequência de rios, comparativamente menores que os obtidos para os outros parâmetros (densidade de drenagem, comprimento médio de rios e razão de textura), assegura maior consistência ao refletir a influência do fator solo no desenvolvimento das redes de drenagem extraídas tanto de aerofotografias, quanto de imagem TM/Landsat e, na seguinte proporção:

$$
\begin{aligned}
& \text { fotografias aéreas - Fr } \rightarrow \mathrm{T} \rightarrow \mathrm{Dd} \rightarrow \mathrm{Lm}, \\
& \mathrm{TM} / \text { Landsat - } \mathrm{Fr} \rightarrow \mathrm{Dd} \rightarrow \mathrm{T} \rightarrow \mathrm{Lm} ; \mathrm{e}
\end{aligned}
$$

c) Todas as variáveis estudadas nas unidades fisiográficas extraídas da imagem de Radar (escala de 1:250.000), não ocorrem com significância. Esse fato demonstra que todos os parâmetros quantitativos estudados da rede de drenagem superficial, não são capazes de acusar diferenças estatísticas significativas, entre pelo menos dois dos três grupos formados pela Análise de Agrupamentos. 
A contribuição de cada uma das variáveis de interpretação da rede de drenagem (densidade de drenagem, frequência de rios, comprimento médio de rios e razão de textura) na distinção entre os grupos formados a partir da Análise de Agrupamentos, pode ser analisada através da aplicação do Teste de Tukey (GOMES, 1987).

Assim sendo, pela Tabela 14 pode-se verificar que a densidade de drenagem (Dd) é um parâmetro que apresenta resultados consistentes para a separabilidade dos agrupamentos pois, quando calculada para a rede de drenagem de unidades fisiográficas extraídas de aerofotografias, distinguem-se os GR 2 (com solos A e SM) e GR 5 (com PVL) dos demais, além de acusar a semelhança existente entre o GR 4 (com LV e PVL) e o GR 3 (com LV e Li-gr).

Quando aplicada em dados extraídos da imagem TM/Landsat, a densidade de drenagem distingue o GR 9 (com SM) dos demais, isto é, de GR 6 (com SM e A), de GR 8 (com LV, PVL, Li-gr e SM), de GR 7 (com LV e PVL).

Porém, quando aplicada aos dados extraídos da imagem de Radar, a densidade de drenagem não consegue nenhuma diferenciação entre os agrupamentos, devido às limitações impostas pela própria escala 1:250.000.

Tanto os resultados obtidos para a escala aproximada de $1: 25.000$, quanto para a escala 1:50.000, concordam com as observações de STRAHLER (1957), que coloca a densidade de drenagem como um importante indicador da escala linear de elementos fisiográficos, bem como com os resultados de SOUZA (1957), NOGUEIRA (1979), PIEDADE (1980), VALÉRIO FILHO (1984), PFEIFER (1984) 
Tabela 14 - Resultados do Teste de Tukey, ao nível de 5\% de probabilidade, para a variável DENSIDADE DE DRENAGEM.

\begin{tabular}{|c|c|c|c|c|}
\hline $\begin{array}{l}\text { Produto de } \\
\text { sensor renoto }\end{array}$ & $\begin{array}{l}\text { Agrupamento } \\
\text { de Tukey * }\end{array}$ & Média & $\begin{array}{l}\text { № de } \\
\text { obs. }\end{array}$ & $\begin{array}{l}\text { Grupo } \\
\text { (GR) }\end{array}$ \\
\hline & A & 6,22 & 03 & 2 \\
\hline & A & 6,06 & 04 & 5 \\
\hline Aerofotografia & A & 4,76 & 04 & 4 \\
\hline \multirow[t]{4}{*}{$(1: 25000)$} & A & 4,61 & 03 & 3 \\
\hline & B & 2,70 & 14 & 1 \\
\hline & A & 6,92 & 02 & 9 . \\
\hline & B & 1,92 & 12 & 6 \\
\hline TH/LANDSAT & B & 1,81 & 04 & 8. \\
\hline \multirow[t]{2}{*}{$(1: 50000)$} & B & 1,10 & 02 & 7 \\
\hline & A & 0,99 & 03 & 11 . \\
\hline Radar & A & 0,76 & 01 & 10 \\
\hline$(1: 250000)$ & A & 0,20 & 02 & 12 \\
\hline
\end{tabular}

* Agruparento de Tukey con ura meswa letra, não diferem entre si. 
e VETTORAZZI (1988), que também verificam a grande eficiência desse índice na diferenciação entre solos, visto que a densidade de drenagem é um parâmetro que se reveste de grande importância, proporcionando uma idéia das características do perfil, representadas pela profundidade, estrutura dos horizontes, relevo da área e resistência à erosão.

Pela Tabela 15 nota-se que a frequência de rios (Fr) também é um parâmetro que apresenta resultados consistentes para a separabilidade dos agrupamentos pois, quando aplicado em dados fornecidos por aerofotografias, distingue os grupos GR 2, GR 4 e GR 5 dos GR 3 e GR 1; quando aplicada aos dados extraídos de imagem de satélite, distingue o GR 9 dos demais; e, quando aplicada aos dados da imagem de radar, assim como a densidade de drenagem, não detecta nenhuma diferenciação entre os grupos, pelos mesmos motivos já discutidos, isto é, as limitações para a interpretação de imagens de pequenas escalas.

Tal como ocorre com a densidade de drenagem, a frequência de rios, que relaciona o número total de rios com a área das respectivas unidades fisiográficas, também mostra-se como um índice consistente, evidenciando uma real diferença entre os diversos agrupamentos da Análise Multivariada.

Assim, esta afirmação também é válida para as diferenças apresentadas entre os solos e concordam com os resultados obtidos por VALÉRIO FILHO et al. (1976), CARVALHO (1977), GUIMARÃES (1984) e VETTORAZZI (1985). 
Tabela 15 - Resultados do Teste de Tukey, ao nível de 5\% de probabilidade, para a variável FREQÜÊNCIA DE RIOS.

\begin{tabular}{|c|c|c|c|c|}
\hline $\begin{array}{l}\text { Produto de } \\
\text { sensor remoto }\end{array}$ & $\begin{array}{l}\text { Agrupanento } \\
\text { de Tukey * }\end{array}$ & Média & $\begin{array}{l}\text { No de } \\
\text { obs. }\end{array}$ & $\begin{array}{l}\text { Grupo } \\
\text { (GR) }\end{array}$ \\
\hline & A & 34,35 & 03 & 2 \\
\hline Aerofotografia & A & 32,41 & 04 & 4 \\
\hline \multirow[t]{4}{*}{$(1: 25000)$} & A & 32,35 & 04 & 5 \\
\hline & B & 20,73 & 03 & 3 \\
\hline & B & 13,86 & 14 & 1 \\
\hline & A & 20,83 & 02 & 9 \\
\hline TH/LANDSAT & B & 8,21 & 12 & 6 \\
\hline \multirow[t]{3}{*}{$(1: 50000)$} & B & 7,13 & 04 & 8 \\
\hline & B & 7,08 & 02 & 7 \\
\hline & A & 1,45 & 03 & 11 \\
\hline Radar & A & 1,19 & 01 & 10 \\
\hline$(1: 250000)$ & A & 0,62 & 02 & 12 \\
\hline
\end{tabular}

* Agrupamento de Tukey con uma mesma letra, näo diferem entre si. 
Portanto, os resultados obtidos concordam com a sugestão de HORTON (1945), no sentido de se utilizar os parâmetros - densidade de drenagem e frequência de rios - com a finalidade de caracterizar quantitativamente as redes de drenagem superficial, pois estas duas características relacionam a composição da rede (comprimento total e número de segmentos de rios) à área de uma unidade fisiográfica.

Pela Tabela 16, observa-se que os comprimentos médios de rios não permitem uma distinção entre os agrupamentos, tal qual CARVALHO (1977 e 1981) e PFEIFER (1984) observam na separabilidade de unidades de solo, o que discorda de FRANÇA (1968) e VETTORAZZI (1988), que estabelecem diferenças entre os solos estudados a partir deste índice.

Através da Tabela 17, nota-se que a variável razão de textura (T) é o melhor parâmetro para a diferenciação entre os agrupamentos, quando aplicada à rede de drenagem superficial de unidades fisiográficas extraídas de fotografias aéreas, na escala aproximada de 1:25.000, pois distingue o GR 5 de GR 3 e GR 4, que por sua vez, distinguem-se de GR 2 e GR 1. Portanto, ocorre uma semelhança entre si em GR 3/GR 4, bem como entre GR 2/GR 1. Quando aplicada em dados extraídos de imagens TM/Landsat, distingue o GR 8 dos demais (GR 9, GR 6 e GR 7), porém quando aplicada aos dados do Radar, a razão de textura não permite uma distinção entre os agrupamentos. 
Tabela 16 - Resultados do Teste de Tukey, ao nível de $5 \%$ de probabilidade, para a variável COMPRIMENTO MÉDIO DE RIOS.

\begin{tabular}{|c|c|c|c|c|}
\hline $\begin{array}{l}\text { Produto de } \\
\text { sensor remoto }\end{array}$ & $\begin{array}{l}\text { Agrupanento } \\
\text { de Tukey * }\end{array}$ & Média & $\begin{array}{l}\text { № de } \\
\text { obs. }\end{array}$ & $\begin{array}{l}\text { Grupo } \\
\text { (GR) }\end{array}$ \\
\hline & A & 0,22 & 03 & 3 \\
\hline Aerofotografia & A & 0,19 & 14 & 1 \\
\hline \multirow[t]{4}{*}{$(1: 25000)$} & A & 0,19 & 04 & 5 \\
\hline & A & 0,18 & 03 & 2 \\
\hline & A & 0,15 & 04 & 4 \\
\hline & A & 0,35 & 02 & 9 \\
\hline TH/LANDSAT & A & 0,24 & 12 & 6 \\
\hline \multirow[t]{3}{*}{$(1: 50000)$} & A & 0,19 & 04 & 8 \\
\hline & A & 0,15 & 02 & 7 \\
\hline & A & 0,70 & 03 & 11 \\
\hline Radar & A & 0,64 & 01 & 10 \\
\hline$(1: 250 \quad 000)$ & A & 0,16 & 02 & 12 \\
\hline
\end{tabular}

* Agrupanento de Tukey con una nesæa letra, não diferen entre si. 
Tabela 17 - Resultados do Teste de Tukey, ao nível de 5\% de probabilidade, para a variável RAZÃO DE TEXTURA.

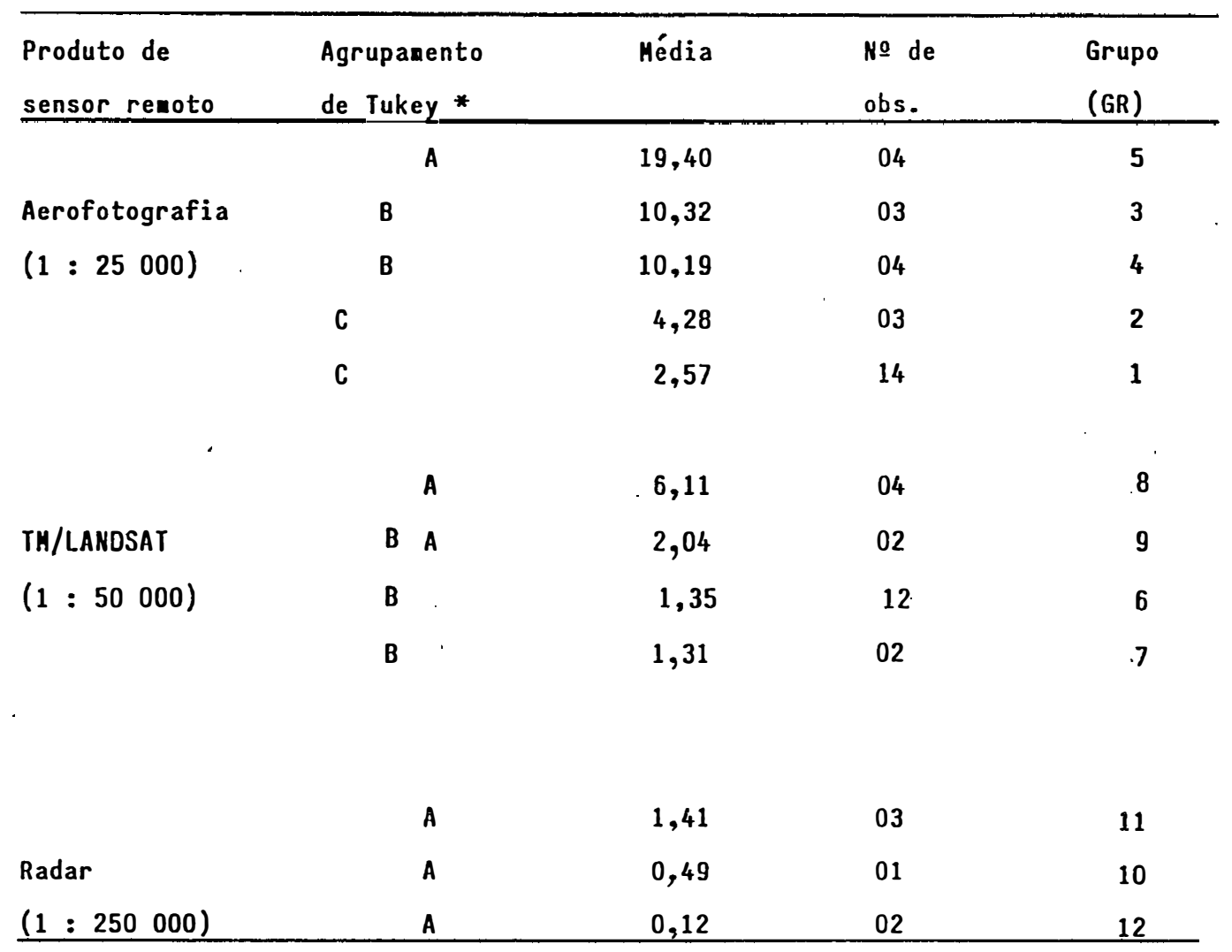

* Agrupamento de Tukey con uma mesma letra, não diferen entre si. 
Tal resultado é esperado pois, a medida que se diminui a escala, diminui também o nível de detalhe que se consegue interpretar; consequentemente, os segmentos de rios de ordens menores não são representados quando da utilização de imagens de Radar. Portanto, o cálculo da razão de textura, segundo SMITH (1950), modificado por FRANÇA (1968), que envolve a relação entre o número total de segmentos de rios e o perímetro da respectiva unidade fisiográfica, fica prejudicado, com a utilização de dados extraídos de imagens de pequenas escalas.

\subsubsection{Características descritivas do padrão de drenagem}

Para a avaliação da eficiência de cada parâmetro qualitativo da rede de drenagem superficial e do relevo, na discriminação entre os grupos de unidades fisiográficas, é utilizada a análise não-paramétrica, efetuada através do Sistema Estatístico SAS. Nesse sistema utiliza-se o procedimento "NPAR1WAY" solicitando-se o cálculo do teste da soma das ordens de Wilcoxon - "Rank Sun Test" - (SAS, 1987). Comumente, ao confrontarmos dois tratamentos, o interesse mäior é o de averiguar se existe superioridade de um sobre o outro quanto à natureza dos dados levantados, ou seja, para dois níveis, o sistema calcula o teste da soma das ordens de Wilcoxon, porém, para qualquer número de níveis, o sistema calcula ("chama") o teste de Kruskal-Wallis que concordando com CAMPOS (1983), é um substituto do Teste F do campo paramétrico e mais indicado para dados qualitativo, ou seja, para índices. 
Para tanto, são apresentados nos Quadros 1 a 11 do Apêndice, as frequências dos índices de cada variável discreta, isto é, para cada característica qualitativa dos padrões de drenagem e do relevo, nos diversos produtos de sensores remotos interpretados.

De uma maneira geral, a análise descritiva do padrão de drenagem determinado através dos elementos propostos por PARVIS (1950) e LUEDER (1959), mostram-se úteis principalmente na abordagem de alguns aspectos que a análise quantitativa desenvolvida por HORTON (1945) e STHRALER (1957) não considera, ao menos expressamente.

O padrão de drenagem resultante do trabalho das águas que atingem, penetram e se escoam pela superfície do terreno, tem suas características descritivas observadas para o P.E. da Ilha do Cardoso agrupados nas Tabelas 6, 7 e 8 e a contribuição de cada um dos elementos de interpretação na distinção entre os grupos, pode ser analisada a partir dos resultados do teste de Kruskal-Wallis, ao nível de 5\% de probabilidade, aplicado a cada uma das características descritivas do padrão de drenagem das unidades fisiográficas e apresentados na Tabela 18.

Para os dados obtidos a partir da fotointerpretação das fotografias aéreas na escala aproximada de 1:25.000, observa-se que os resultados do teste de KruskalWallis, para todas as variáveis, acusam diferença significativa ao nível de $1 \%$ de probabilidade, para pelo menos dois dos cinco grupos formados pela análise multivariada. 


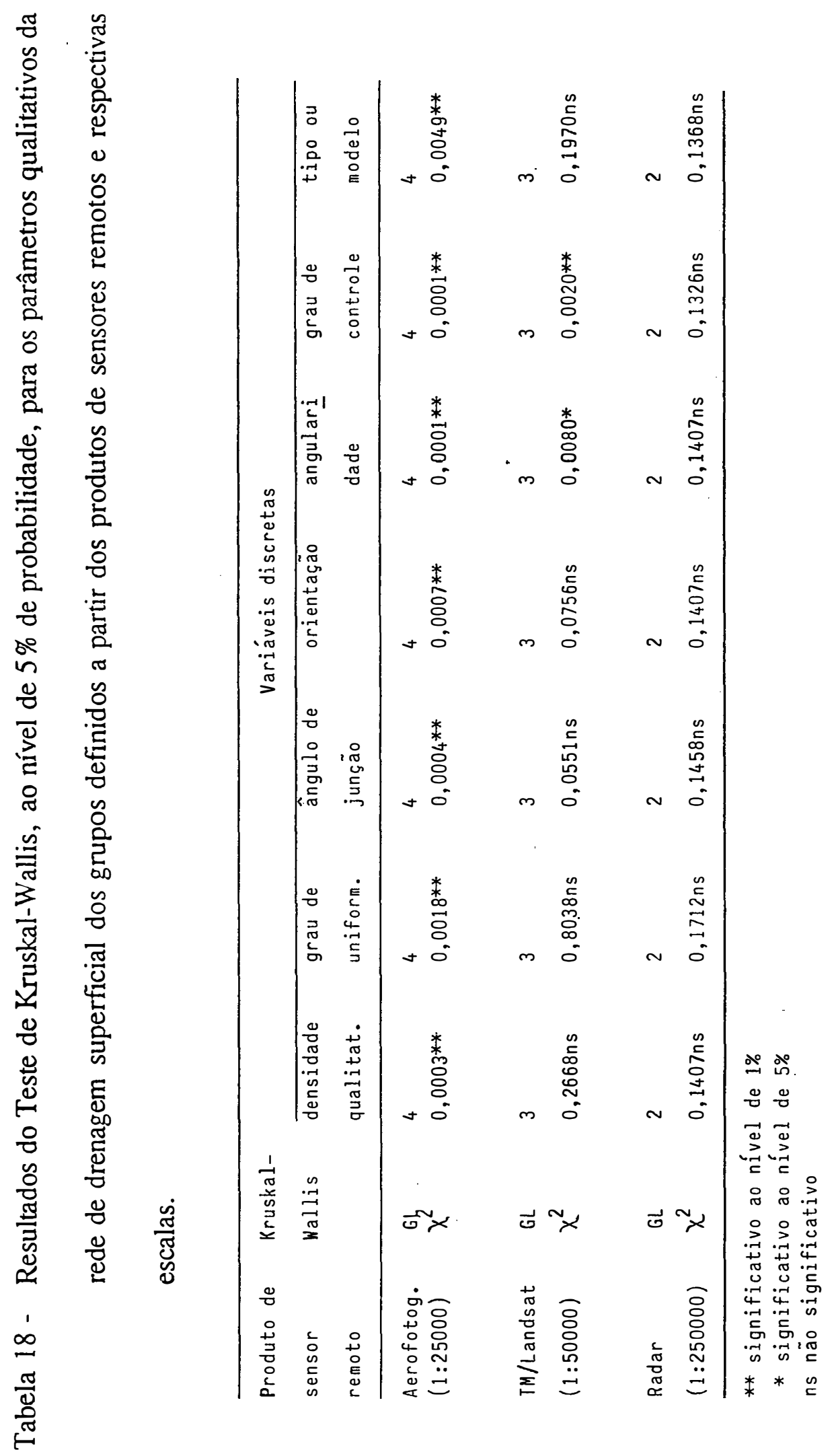


Para os dados obtidos a partir da interpretação da imagem TM/Landsat na escala de 1:50.000, observa-se que os resultados do teste de Kruskal-Wallis, para quase todas as variáveis, não acusam diferença significativa, para pelo menos dois dos cinco grupos formados pela análise multivariada, exceto para as variáveis grau de controle (ao nível de $1 \%$ de probabilidade) e para a variável angularidade (ao nível de $5 \%$ de probabilidade).

Para os dados obtidos a partir da interpretação da imagem de Radar na escala 1:250.000, observa-se que os resultados do teste de Kruskal-Wallis não acusam diferença significativa entre dois dos três grupos formados pela análise multivariada, para todas as variáveis qualitativas da rede de drenagem analisadas.

Levando-se em consideração estes fatos, pode-se afirmar que, dentre as características qualitativas da rede de drenagem, a mais eficiente na distinção entre os grupos é grau de controle, pois só não apresenta diferença significativa entre os grupos, nos dados interpretados na imagem de Radar, pelos motivos já discutidos das limitações apresentadas pela interpretação de pequenas escalas (1:250.000), discordando de VETTORAZZI (1988) que obteve pouca contribuição desse índice na discriminação entre os grupos. O grau de controle refere-se a relativa dominância de orientação, portanto uma rede de drenagem superficial com um alto grau de controle apresenta os segmentos de rios, exclusivamente, com direções orientadas e com alta angularidade, inferindo que o controle pode ser estrutural em Li-gr (observações 28/48/54) e litológico em PVL (observações 27/47/53), o que concorda com PFEIFER (1984). 
Outro elemento, a angularidade, também apresenta boa eficiência. A angularidade refere-se as variações bruscas de direção dos segmentos de rios podendo indicar a presença de rocha próxima à superfície ou no leito do rio, assim como estruturas de diáclases e/ou falhamentos (LUEDER, 1959).

Concordando com FRANÇA (1968), a descrição detalhada do padrão de drenagem, em termos de suas principais características, facilita a análise do padrão, porém, como LUEDER (1959) reconhece, a interpretação de sua significância não é simples, requerendo uma combinação de avaliação teórica com experiência no processo de correlacionar aspectos da imagem fotográfica com as condições reais do terreno.

Para sanar tal problema, os resultados obtidos mostram a necessidade e a importância das características quantitativas que, baseando-se em simples medições, colocam a descrição do padrão de drenagem em termos mais objetivos, exatos e reproduzíveis, permitindo a elaboração de comparações e interpretações em bases mais concretas e significativas, desde que sejam superadas certas dificuldades no tipo de amostragem, no tipo de material fotográfico empregado e na respectiva escala utilizada.

Baseando-se nesta assertiva e pelos resultados obtidos com os estudos da drenagem superficial, pode-se sugerir que as fotografias aéreas na escala aproximada de 1:25.000 são úteis para levantamentos à nível de semidetalhe, as imagens TM/ Landsat na escala 1:50.000 podem auxiliar os levantamentos de reconhecimento; e, as imagens de radar na escala de 1:250.000, pela grande área que recobrem (continuamente), são de grande utilidade para os levantamentos mais generalizados (exploratórios). 


\subsection{Avaliação da eficiência dos elementos de interpretação do relevo}

O relevo associado aos fatores climáticos e pedológicos comanda a capacidade de infiltração, além de determinar o tipo de escoamento superficial. Concordando com as afirmações de PIEDADE (1980) e CARVALHO (1981), a conformação do terreno representa um componente de grande importância do sistema natural que os solos do P.E. da Ilha do Cardoso representam. Essa conformação comporta duas das três dimensões do solo: a superfície de exposição e a forma, o que permite ao relevo condicionar as drenagens internas e externas do corpo do solo.

O relevo, por comandar a circulação de água nos solos, possui sua evolução ligada à das formações superficiais. A condição de um relevo suavemente ondulado propicia, normalmente, a existência de solos mais evoluídos (maduros), enquanto que relevos fortemente ondulados suportam solos mais jovens.

Com o intuito de interpretar e comparar as unidades fisiográficas é efetuada a fotoanálise do relevo. No exame estereoscópico das fotografias aéreas, o relevo é o elemento que mais se destaca, permitindo um exame mais minucioso, auxiliado pelo exagero da escala vertical, acentuando a topografia e evidenciando os relevos suaves. Havendo variações nas formas de relevo, pode-se esperar mudanças nos tipos de solos, pois esse elemento constitui um dos seus fatores de formação. Estando o relevo correlacionado com a relação infiltração/deflúvio, extremamente importante aos processos de formação de um solo, o relevo pode ser desmembrado em seus 
elementos para melhor caracterizar os solos das unidades fisiográficas em: tipo de relevo, classe de relevo, comprimento de vertente e posição topográfica.

A contribuição de cada um dos elementos de interpretação na distinção entre os grupos, pode ser analisada a partir dos resultados do teste de Kruskal-Wallis, ao nível de $5 \%$ de probabilidade, aplicado a cada uma das variáveis discretas do relevo apresentados na Tabela 19.

Observando-se a referida Tabela, nota-se que a contribuição de cada um dos elementos de interpretação é idêntica, tanto aos dados extraídos de aerofotografias (escala aproximada de 1:25.000) quanto aos dados extraídos de imagem TM/Landsat (escala de 1:50.000). Nos dois produtos de sensor remoto e respectivas escalas, todas as variáveis foram significativas ao nível de $1 \%$ de probabilidade, exceção feita ao comprimento de vertente. Porém, quanto aos dados extraídos de imagem de Radar (escala de 1:250.000), nenhum elemento é capaz de mostrar diferenças significativas na diferenciação dos grupos.

Portanto, de um modo geral, pode-se considerar bom o desempenho das variáveis - tipo de relevo, classe de relevo e posição topográfica - na Análise de Agrupamentos, o que vem a confirmar os resultados obtidos por diversos autores para o critério relevo, na diferenciação entre solos (MARCHETTI, 1969; KOFFLER, 1982; LEÃO, 1983; VALÉRIO FILHO, 1984; ANGULO FILHO, 1986; SILVA, 1988 e VETTORAZZI, 1988). 
Tabela 19 - Resultados do Teste de Kruskal-Wallis, ao nível de $5 \%$ de probabilidade, para os parâmetros do relevo dos grupos (GR) definidos a partir dos produtos de sensores remotos e respectivas escalas.

\begin{tabular}{|c|c|c|c|c|c|}
\hline \multirow{2}{*}{$\begin{array}{l}\text { Produto de } \\
\text { sensor remoto }\end{array}$} & \multirow{2}{*}{$\begin{array}{l}\text { Kruskal- } \\
\text { Mallis }\end{array}$} & \multicolumn{3}{|c|}{ Variáveis discretas } & \multirow[b]{2}{*}{$\begin{array}{l}\text { posigāo } \\
\text { topográf. }\end{array}$} \\
\hline & & $\begin{array}{l}\text { tipo de } \\
\text { relevo }\end{array}$ & $\begin{array}{l}\text { classe de } \\
\text { relevo }\end{array}$ & $\begin{array}{l}\text { comprimento } \\
\text { de vertente }\end{array}$ & \\
\hline Aerofotografia & $6 L^{\circ}$ & 4 & 4 & 4 & 4 \\
\hline$(1: 25000)$ & $x^{2}$ & $0,0001 * *$ & $0,0001 * *$ & $0,1123 \mathrm{~ns}$ & $0,0001 * *$ \\
\hline TH/LAKDSAT & GL & 3 & 3 & 3 & 3 \\
\hline$(1: 50000)$ & $x^{2}$ & $0,0022 * *$ & $0,0022 * *$ & $0,2135 \mathrm{~ns}$ & $0,0017^{* *}$ \\
\hline Radar & GL & 2 & 2 & 2 & 2 \\
\hline$(1: 250000)$ & $x^{2}$ & $0,2829 \mathrm{~ns}$ & $0,2829 n s$ & $0,0821 \mathrm{~ns}$ & $0,0821 \mathrm{~ns}$ \\
\hline
\end{tabular}

* significativo ao nível de $1 \%$

* significativo ao nível de $5 \%$

ns nāo significativo 
Analisando-se conjuntamente a fotoanálise do relevo, as Figuras 13, 14 e 15 e a Tabela 9, nota-se que para as unidades fisiográficas equivalentes, isto é, determinadas pela Análise de Agrupamentos aplicada aos dados extraídos dos diversos produtos de sensores remotos, tem-se:

a) Observações 22/44/51- esta unidade possui como solo predominante o Latossolo Vermelho-Amarelo-Orto (LV) assente em relevo do tipo normal, onde a relação infiltração/deflúvio praticamente se equivale, ocupando as posições topográficas mais elevadas nas quais não se observa a predominância de nenhum fator de formação. A classe de relevo predominante é ondulado cujas superfícies são movimentadas, com diferenças de nível inferiores à 50m e declives suavizados em virtude do comprimento das vertentes - muito longo (acima de 500m). A ocorrência do B latossólico no P.E. da Ilha do Cardoso é explicada por PFEIFER \& DOMINGUES (1983/85) pela existência de rochas cataclásticas e pelos falhamentos que possibilitam, por intermédio da ação dos processos geomorfológicos, o aparecimento dos interflúvios mamelonados e de formações superficiais mais espessas;

b) Observações 27/47/53 - o solo predominante dessa unidade fisiográfica é o Podzólico Vermelho-Amarelo "intergrade" para Latossolo Vermelho-Amarelo (PVL) assente em relevo que varia de normal a excessivo. A classe de relevo predominante é forte ondulado, com superfícies movimentadas, ṕresença de outeiros e diferença de nível 
entre 50 e $100 \mathrm{~m}$, com declives moderados. O comprimento dominante das vertentes também é classificado em muito longo, ocupando as mais diversas posições topográficas. Pelos mesmos motivos dos Latossolos, PFEIFER \& DOMINGUES (1983/85) explicam a presença desse B textural "intergrade"; e

c) Observações 28/48/54 - a formação superficial dessa unidade fisiográfica é o Litossolo-fase substrato granito-gnaisse (Li-gr) assente em relevo do tipo excessivo, onde a infiltração é menor do que o deflúvio. Esse tipo de relevo é típico de solos pouco desenvolvidos, onde os processos erosivos são maiores do que os de formação do solo e o deflúvio superficial é mais rápido em virtude da classe de relevo montanhoso (superfícies movimentadas com presença de morros e diferenças de níveis entre 100 e $200 \mathrm{~m}$, com fortes declives). Ocupam as mais diversas posições topográficas e possuem um comprimento de vertente classificada como muito longa (acima de 500m). SUDELPA (1975) observa que a estrutura, delineada pelos dobramentos, possibilita aos processos de retrabalhamento da superfície, o encaixe da drenagem em vales profundos e a ocorrência desse tipo de solo (Litossolo) com padrões rochosos em áreas de topos em cristas, com vertentes retilíneas e movimentos de massas lineares e areolares (as cicatrizes quase sempre expõem a rocha e o solo, enquanto que as aerolares formam extensos paredões rochosos).

Pode-se dizer também que a análise detalhada dos padrões de drenagem e do relevo na imagem de radar (esc. de 1:250.000) é prejudicada, pelas condições da 
área de estudo. Provavelmente, a alta densidade de drenagem da rede hidrográfica do P.E. da Ilha do Cardoso faz com que os canais de pequenas dimensões e pouco espaçados, não possam ser individualizados na imagem. Deve-se considerar, ainda, o tipo de vegetação da Unidade de Conservação, que por sua densidade, dificulta a identificação de rios ao nível desse sensor remoto.

Acredita-se que outro fator limitante relacionado com o sistema de imageamento, que pode ter dificultado a representação fotográfica de qualidade suficiente para esse tipo de interpretação visual, tenha sido em virtude da utilização de mosaico semicontrolado, cópia "off set". Tal fato sugere a realização de trabalhos futuros com processamento automático, eliminando-se assim, várias fases do processamento de imagens, que podem causar perdas de resolução.

Contudo, a análise da eficiência dos elementos de interpretação do relevo nas várias escalas estudadas sugerem, à exemplo da interpretação quantitativa e qualitativa da drenagem superficial que:

* as fotografias aéreas (escala aproximada de 1:25.000) são úteis na realização de levantamentos de solos em nível de semidetalhe;

* as imagens TM/Landsat (escala de 1:50.000) podem auxiliar os levantamentos de reconhecimento; e

* as imagens de radar (escala de 1:250.000), pela grande área que recobrem (continuamente), com apenas uma imagem, auxiliam os levantamentos regionais mais generalizados (exploratórios). 


\subsection{Considerações sobre os resultados da Análise de Agrupamentos}

Concordando com CARDOSO (1988), SILVA (1988), VETTORAZZI (1988) e CARVALHO et al. (1990), a aplicação da Análise de Agrupamentos para os dados obtidos pela interpretação de aerofotografias, imagens orbital e de radar do P.E. da Ilha do Cardoso, visando à formação de grupos homogêneos de unidades fisiográficas, mostra-se de grande utilidade, orientando a operação de agrupamento e possibilitando a associação do grau de dificuldade na distinção das unidades com a escala de valores numéricos (coeficientes de semelhança). Mostra também que, para as três escalas estudadas, os critérios rede de drenagem e relevo podem ser aplicados com resultados satisfatórios na interpretação visual de produtos de sensores remotos visando a caracterização fisiográfica para mapeamento de solos, obviamente observando-se as limitações impostas pelas escalas ao nível de detalhamento.

A coerência verificada entre as características da rede de drenagem superficial e do relevo, nos grupos formados com os respectivos tipos de solos é a comprovação da aplicabilidade da Análise de Agrupamentos. A exemplo dos grupos - GR 4, GR 7 e GR 12 - que separam os 2 (dois) morrotes isolados (existentes no Parque) que apresentam, predominantemente, solos com horizontes B latossólico e B textural. A análise qualitativa da rede de drenagem superficial das unidades fisiográficas constituídas pelo Latossol Vermelho-Amarelo-Orto revela que o modelo subparalelo, não uniforme, pouco orientado e com grau médio de controle são bons indicativos do desenvolvimento da rede sobre esse tipo de formação superficial. 
Este tipo de observação também pode ser notada para o caso dos Solos Podzólicos Vermelho-Amarelo "intergrade" para Latossol Vermelho-Amarelo, cujo modelo dendrítico da rede de drenagem e o médio grau de controle aliado à uniformidade e a não orientação da rede conferem os bons resultados, além de indicarem o tipo de material sobre o qual a rede de drenagem se desenvolve.

Os resultados quantitativos, sintetizados na Tabela 20, também demonstram a estreita correlação entre o grau de evolução e a susceptibilidade à erosão dos tipos de solos característicos das unidades fisiográficas estudadas.

Analisando-se as médias gerais, observa-se que os maiores valores encontrados para densidade de drenagem, frequência de rios e razão de textura ocorrem nas unidades com horizonte B textural, conferindo-lhe características susceptíveis à erosão, o que concorda com a afirmação de RAY (1963), segundo a qual, à medida que diminui a resistência à erosão hídrica, ocorre um aumento na densidade da rede de drenagem superficial, bem como a observação de FRANÇA (1968), segundo a qual a relação (Susceptibilidade a erosão/Densidade de drenagem) não depende apenas do tipo de material sobre o qual a rede de drenagem encontra-se, mas também da natureza dos solo que se desenvolvem a partir desse material.

A textura topográfica (Tt), classificada segundo FRANÇA (1968), também revela-se um ótimo indicador para a separabilidade, isto é, para a distinção entre solos morfogeneticamente semelhantes, classificando como textura topográfica fina os PVL e Li-gr; como média os LV; e como grosseira os A e SM. 


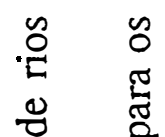

.ㄱ 1

总

总 苮

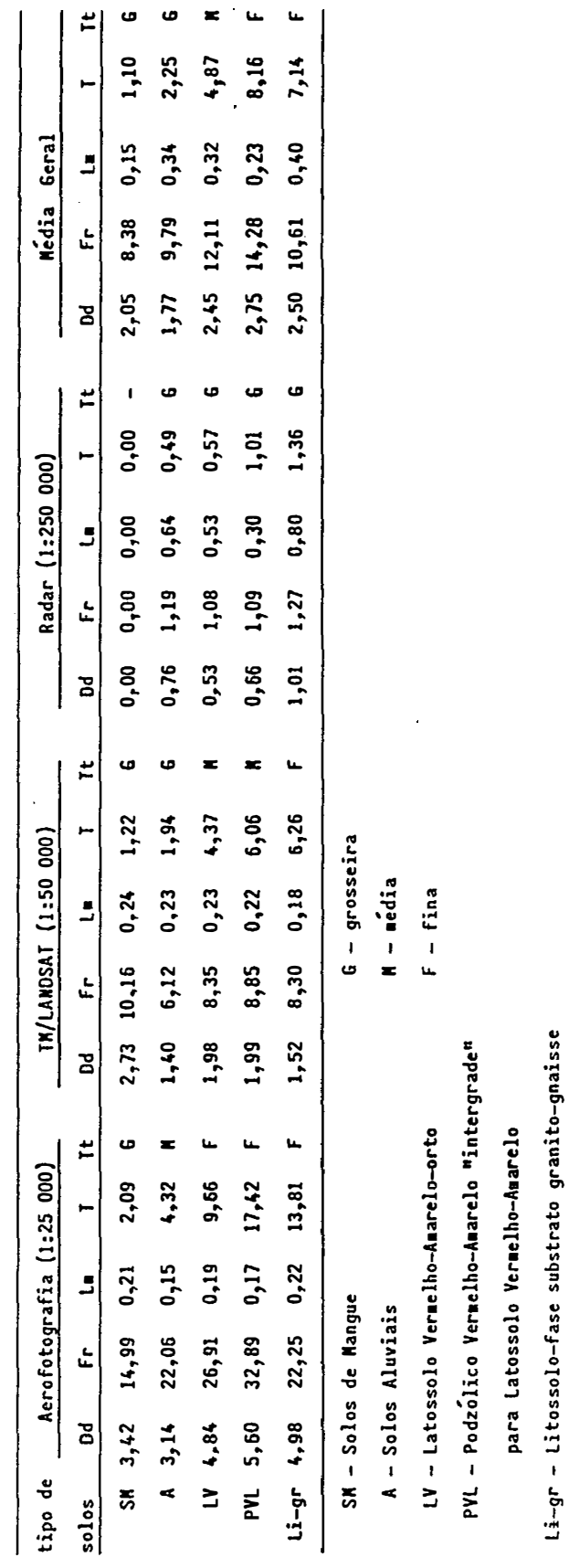

壳 䍃

点 站

. \&

ป E

兽 导

志

iิ

ह

苞

ㅇํㅇ

管

过

苞苞

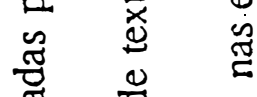

苛 范

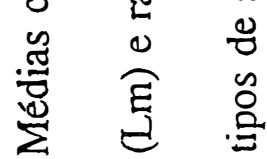

ᄋ̊

$\frac{\pi}{\mathbb{0}}$ 
O comprimento médio de rios, quando calculado segundo a média aritmética, indica pequenas variações entre os dados, o que concorda com CARVALHO (1981) e PFEIFER (1984) que observam a pouca significância desse índice na diferenciação entre solos. Esse fato, provavelmente, não permite uma interação entre o número e o comprimento total de segmentos de rios que possam resultar, para o P.E. da Ilha do Cardoso, um ajustamento da equação proposta por VASQUES FILHO (1972) e um enquadramento na lei dos comprimentos médios de HORTON (1945). Porém concordando com FRANÇA (1968), o comprimento médio dos segmentos de rios, classificados segundo a ordem de ramificação, é outra característica relacionada ao comportamento hidrológico do solo, embora seja mais susceptível de variação por controle geológico ou topográfico. Assim o Litossolo-fase substrato granito-gnaisse é o que apresenta os maiores comprimentos médios de rios, seguidos pelos Solos Aluviais e Latossolo Vermelho-Amarelo-Orto. O Podzólico Vermelho-Amarelo "intergrade" para Latossolo Vermelho-Amarelo e os Solos de Mangue são, dentre os solos estudados, os que condicionam o desenvolvimento de segmentos de rios com os menores comprimentos médios.

Portanto, a correlação encontrada entre as características do padrão de drenagem, para cada grupo formado e os respectivos solos, está de acordo com as afirmações de GARCIA et al. (1981) e VETTORAZZI (1988), de que a rede de drenagem destaca-se entre os critérios interpretativos, uma vez que a gênese está ligada a condições que também determinam o desenvolvimento das unidades de solo. Em parte 
também concorda com LUEDER (1959) que ressalta a importância do padrão de drenagem, ao afirmar que "depois do relevo, a rede de drenagem superficial é o mais consistente e confiável indicador das condições reais do terreno".

Concordando com HORTON (1945), SMITH (1950), STRAHLER (1952)

e GOOSEN (1967), a relação existente entre a rede de drenagem e o relevo, também pode ser observada nos resultados obtidos.

Concordando com VETTORAZZI (1988), o relevo forte ondulado e o tipo excessivo, associado aos Litossolos, favorece o deflúvio, em detrimento da infiluração, aumentando a ação erosiva das águas pluviais e resultando na formação de muitos canais de escoamento e consequentemente numa alta densidade de drenagem. $\mathrm{O}$ outro extremo da situação, nas unidades fisiográficas associadas aos Latossolos, a infiltração bastante favorecida pela condição de relevo suave ondulado (além das características do próprio solo), condiciona uma rede de drenagem de densidade mais baixa, comparativamente.

4.10. Considerações sobre as relações interpretativas dos parâmetros da drenagem e do relevo com os diversos produtos de sensores remotos

Estabelecendo-se as relações interpretativas dos resultados alcançados para os índices de drenagem e relevo na diferenciação entre solos é que se demonstra as razões pelas quais é possível realizar a compartimentação da área de estudo em unidades fisiográficas. 
Concordando com GIMBARZEVSKY (1974a), PACHECO \& HOWARD (1977), MONTOYA (1977), SEGOVIA et al. (1980), COCHRANE \& BROWNE (1981) e VALÉRIO FILHO (1984), não é apenas a "aparência" que define uma unidade fisiográfica, mas a integração dos atributos espaciais e espectrais da drenagem, do relevo e dos aspectos associados que ocupam uma disposição na superfície do terreno, que torna possível o delineamento desse tipo de amostragem.

Outro fator que auxilia a delimitação de unidades fisiográficas e a interpretação de imagens de pequena escala é o efeito de luz e sombra. A exemplo das vertentes que se apresentam com diferenças (declividade e comprimento) suficiente para causarem variações na tonalidade registrada na imagem fotográfica - visto que a superfície do terreno reflete os raios solares diretamente em direção ao sensor remoto e, através desta variação tonal, as variações topográficas podem ser inferidas pelas diferenças de tons de áreas iluminadas e sombreadas, as quais proporcionam uma clara idéia da forma do relevo.

Isto posto, pode-se dizer que a razão da individualização dos diversos tipos de solos analisados nos diversos produtos de sensores remotos, está diretamente relacionada com as feições da textura fotográfica, o que concorda com VALÉRIO FILHO (1984).

Embora os atributos do relevo associados à drenagem tenham sido os fatores mais influentes para evidenciar distintas texturas fotográficas, a interpretação da vegetação também proporciona uma importante contribuição, tornando possível uma 
compartimentação mais eficiente na área do estudo. A exemplo das unidades fisiográficas constituídas, predominantemente, com solos de Mangue, cujo tipo de cobertura vegetal, por sua textura fotográfica, possibilitou a delimitação mais eficiente desse tipo de solo e consequentemente, a individualização das unidades fisiográficas.

Este fato demonstra que a análise interpretativa dos diversos produtos de sensores remotos deve ser realizada, em qualquer tipo de amostragem, pela convergência de evidências e não através de um único parâmetro, o que concorda com GARCIA (1979) e DONZELI et al. (1983).

Com relação aos resultados obtidos para as interpretações nas diversas escalas estudadas, pode-se considerar que:

a) As unidades fisiográficas podem ser identificadas e delineadas, tanto em aerofotografias na escala aproximada de 1:25.000, quanto em imagem TM/Landsat composição colorida 3,4,5 - na escala de 1:50.000, como em imagem de radar - cópia "off set" do mosaico semicontrolado - na escala de 1:250.000;

b) Os elementos de interpretação mais eficientes na delimitação de unidades fisiográficas são a rede de drenagem superficial e o relevo, enquanto que os elementos textura, tonalidade e vegetação são úteis como parâmetros auxiliares na identificação das paisagens associadas aos solos, o que discorda de BARR \& MILES (1970) e concorda com CARNEIRO (1975), MONTOYA (1977) e VALÉRIO FILHO et al. (1979); 
c) O nível de detalhe geral do padrão de drenagem extraídos de aerofotografias e de imagem TM/Landsat se aproximam (com uma ligeira vantagem à interpretação dos dados obtidos a partir de fotografias aéreas na escala aproximada de 1:25.000), enquanto que o detalhamento obtido arravés dos dados extraídos da imagem de radar é prejudicado, isto é, mais generalizado. Portanto, o nível de informação é controlado pela escala da imagem, pela resolução do sistema e pelos aspectos superficiais de visibilidade dos canais de drenagem, o que concorda com KOOPMANS (1973), KOFFLER (1976a) e EPIPHANIO et al. (1983);

d) Os elementos do relevo como tipo, classe e posição topográfica, são caracterizados por uma alta relação com as condições de solo e uma alta coincidência com os limites das unidades fisiográficas e portanto podem ser considerados como um dos critérios importantes para a fotopedologia - concordando com ROURKE \& AUSTIN (1951), LUEDER (1959), MARCHETTI (1969), WONG et al. (1977) e POLITANO (1980) enquanto que o elemento comprimento de vertente pouco contribui para a separabilidade dos agrupamentos. Tais fatos verificam-se na mesma proporção dos encontrados para a rede de drenagem, isto é, resultados semelhantes e significativos para aerofotografias e imagem TM/Landsat e não significativos para a imagem de radar; e que

e) Os elementos de interpretação, nos diversos produtos de sensores remoto, aplicados ao estudo dos solos não devem ser analisados isoladamente, mas sim conjuntamente 
pois, os diversos critérios de interpretação não se substituem, mas complementam-se. Concordando com GARCIA (1979) e DONZELI et al. (1983), pode-se sugerir também que maior atenção deve ser dada à aplicação conjugada das três fontes de informações.

Finalizando, diante do exposto, pode-se dizer pelos resultados obtidos nesta investigação, que materiais de textura semelhante e depositados pelo mesmo agente de transporte devem ter dado origem aos solos diferentes, cujas diferenças se refletem também na composição e nas características do padrão de drenagem e no relevo do P.E. da Ilha do Cardoso.

Até certo ponto, os resultados obtidos concordam com as observações de HORTON (1945) e FRANÇA (1968) que enfatizam as condições do solo, reconhecendo como fatores importantes no desenvolvimento de sistemas hidrológicos, a capacidade de infiltração do solo e a resistência à erosão, observando-se que o grau de manifestação destes atributos varia de uma unidade de solo para outra, em função do conjunto de propriedades que caracteriza cada unidade.

Os resultados concordam com as observações de PARVIS (1950), LUEDER (1959) e FROST (1960), uma vez que fazem referências à capacidade de infiltração ou à relação infiltração/deflúvio, bem como à resistência do solo ou da rocha à erosão.

A análise dos materiais e métodos utilizados, somados aos resultados obtidos, permitem constatar, corroborando com as observações e conclusões de 
PFEIFER (1981/82), PFEIFER \& DOMINGUES (1983/85) e PFEIFER et al. (1989), que a região do P.E. da Ilha do Cardoso é de alta pluviosidade e de umidade relativa elevada, o que possibilitam a existência da densa cobertura vegetal e a farta rede de drenagem; a evolução do relevo está ligada à das formações superficiais e associada aos fatores climáticos e pedológicos que comandam a capacidade de infiltração, além de determinarem o tipo de escoamento superficial; o padrão de desenvolvimento da rede de drenagem reflete principalmente na influência de um controle litológico; a litologia composta de rochas que dão, em sua maioria, solos que favorecem o escoamento subsuperficial, impedindo a água de se infiltrar mais profundamente, mantendo assim a perenidade dos rios; a densa rede de drenagem não permite o completo assoreamento da baixada, convertendo-a em um emaranhado de restingas, ilhas, rios e canais; a planície aluvial, além de outros fatores é originária da ação do clima e da circulação da água, que causam a decomposição das rochas, dos compartimentos topomorfológicos superiores e fornecem farto material de sedimentação, os quais, transportados pelos rios são depositados nas baixadas costeiras; e o tectonismo é bastante evidente, pelos traços estruturais, disposição dos interflúvios e formas dos topos, nos quais os solos eluviais desenvolvem-se (sobre as rochas do Complexo Gnáissico-Migmatítico e do Grupo Açungui), sugerindo que suas formações podem ter ocorrido em função dos dobramentos sofridos pelas rochas durante o tectonismo, permitindo o aprofundamento dos vales, a sedimentação vertical e o aparecimento dos solos profundos em relevo acidentado. 


\section{CONCLUSÕES}

Considerando-se os objetivos deste trabalho, os materiais e métodos empregados, as condições específicas sob as quais se conduziram, os resultados obtidos, analisados e interpretados permitiram que se chegasse às conclusões apresentadas a seguir:

. no raçado da rede de drenagem, as maiores contribuições são dadas pelas fotografias aéreas, seguidas da imagem TM/Landsat, em relação à imagem de radar;

- as aerofotografias são as que melhores contribuições fornecem à delimitação de área homogêneas, seguidas da imagem orbital, em relação a imagem de radar;

. os critérios rede de drenagem e relevo comprovam, mais uma vez, sua utilidade em trabalhos de interpretação visual dos diversos produtos de sensores remotos, na separabilidade de áreas morfogeneticamente distintas;

- a abordagem estatística utilizada para o tratamento dos dados, mostra-se eficiente e oferece grande confiabilidade aos resultados obtidos; 
. a utilização da Análise de Agrupamentos possibilita a formação de grupos de unidades fisiográficas, relacionados aos solos morfologicamente semelhantes;

. para as escalas 1:25.000 e 1:50.000, o elemento frequência de rios é o que melhor desempenho apresenta, dentre as características quantitativas do padrão de drenagem, na distinção entre as diferentes unidades fisiográficas;

- a variável razão de textura é o melhor parâmetro para a diferenciação entre os agrupamentos, aplicada à rede de drenagem superficial de unidades fisiográficas extraídas de fotografias aéreas;

. as variáveis grau de controle e angularidade, são os elementos mais eficientes, dentre as características qualitativas do padrão de drenagem, para a distinção entre os grupos de unidades fisiográficas extraídas nas escalas 1:25.000 e 1:50.000;

. as características dos padrões de drenagem são condicionadas pela propriedade dos solos, pela posição topográfica que ocupam e pela natureza e profundidade do substrato rochoso;

. as melhores contribuições na separabilidade dos grupos de unidades fisiográficas são fornecidas dentre os elementos do relevo, pela posição topográfica, tipo e classe de relevo, tanto para a escala 1:25.000, quanto para a escala 1:50.000; 
. existe uma tendência de aproximação entre os dados obtidos através de produtos sensores nas escalas 1:25.000 e 1:50.000, dos valores de cada característica quantitativa e qualitativa, reduzindo a separabilidade dos agrupamentos, à medida que a escala diminui para 1:250.000;

- para o nível de detalhamento estudado, as características da rede de drenagem superficial e do relevo não apresentam resultados significativos para a separabilidade dos grupos de unidades fisiográficas na escala 1:250.000 (imagem de radar);

. os elementos de interpretação, nos diversos produtos de sensores remotos, aplicados ao estudo de solos, não devem ser analisados isoladamente, mas conjuntamente, pois os critérios de interpretação não se substituem, mas complementam-se; e

. a metodologia empregada no P.E. da Ilha do Cardoso, mostra-se potencialmente válida para levantamentos de solos, ao nível de semidetalhe realizados com o auxílio da interpretação de fotografias aéreas na escala aproximada de 1:25.000, podendo-se recomendar para levantamentos de reconhecimento a utilização da interpretação de imagem orbital na escala de 1:50.000 e para levantamentos a um nível mais generalizado, o auxílio da interpretação de imagem de radar na escala de 1:250.000. 


\section{REFERÊNCIAS BIBLIOGRÁFICAS}

AB'SABER, A.N. Sensibilidade das fotografias aéreas em zonas tropicais úmidas para efeito de fotointerpretação. Notícia Geomorfológica, Campinas, 3(6):67-72, 1960.

ALMEIDA, F.F.M. Diferenciação da plataforma brasileira. Res. das Conf. e Com. do XXIII CONGRESSO BRASILEIRO DE GEOLOGIA, Bol. Esp., Salvador, n.1:4-5, 1969.

ANDERSON, H.W. Relating sediment yield to watershed variables. Trans. Amer. Geophys. Un., Washington, 38:921-924, 1957.

ANDREWS, A. A B C'S of Radar. Howard W. Sams. The Bobbs - Merril Company, New York, 128p. 1966.

ANGULO FILHO, R. Caracterização da drenagem e do relevo de três solos do Estado de São Paulo, através de fotografias aéreas e cartas planialtimétricas. Piracicaba, 1986. 132p. (Doutorado - Escola Superior de Agricultura "Luiz de Queiroz"/USP).

AUDI, R. Fotointerpretação de atributos dos canais de drenagem em solos da região noroeste do Estado de São Paulo. Piracicaba, 1972. 182p. (Doutorado - Escola Superior de Agricultura "Luiz de Queiroz"/USP). 
AVERY, T.E. Interpretation of aerial photographe. Burgess Publishing Company, Minneapolis, 1968. 319p.

BALEANI, O.A. \& RAED, M.A. Aplicación del análisis digital de imágenes satelitárias en la diferenciación de suelos. In: SIMPÓSIO LATINOAMERICANO (SIMPÓSIO BRASILEIRO, 4.) DE SENSORIAMENTO REMOTO, Gramado, 1986. Anais. São José dos Campos, SELPER/INPE/SBC, 1986. p.7. (Resumo).

BARR, D.J. \& MILES, R.D. SLAR imagey and site selection. Photogrammetric Engineering, Falls Church, 36(11):1155-70, 1970.

BLOOM, A.L. A superfície da terra. Trad. por S. Petri e R. Ellert. Ed. Edgard Blücher Ltda. São Paulo, 1970. 184p.

BOMBERGER, E.H. \& DILL JÚNIOR, H.W. Photointerpretation in agriculture. In: American Society of Photogrammetry. Manual of Photographic Interpretation, Washington, 1960, cap.11, p.561-632.

BRASIL. Ministério da Agricultura. Centro Nacional de Ensino e Pesquisas Agronômicas. Serviço Nacional de Pesquisas Agronômicas. Levantamento de Reconhecimento dos solos do Estado de São Paulo. Rio de Janeiro, 1960. 634p. (Boletim, 12). 
BRINK, A.B.; MABBUTT, J.A.; WEBSTER, R.; BECKETT, P.H.T. Report of the Working Group on Land Cassification and Data Storage. Christchurch, Mexe Rep., 1966. 95p.

BURINGH, P. The applications of aerial photographs in soil surveys. In: AMERICAN SOCIETY OF PHOTOGRAMMETRY. Manual of photographic interpretation. Washington, 1960. ap. A, cap. 11, p.633-66.

CAMPOS, H. de. Estatística Experimental não Paramétrica. Piracicaba, ESALQ/USP, 349p. 1983. (4.ed.).

CARDOSO, L.G. Comportamento das redes de drenagem em solos com cana-deaçúcar e com eucalipto. Botucatu, 1988. 139p. (Doutorado - Faculdade de Ciências Agronômicas/UNESP).

CARNEIRO, C.M.R. Estudo da aplicabilidade de imagens MSS do ERTS-1 em levantamento de solos. Santa Maria, 1975. 63p. (Mestrado - Universidade Federal de Santa Maria).

CARTER, L.D. \& STONE, R.O. Interpretation of orbital photographs. Photogrammetric Engineering, Falls Church, 15(3):193-97, 1974. 
CARVALHO, W.A. Fotointerpretação de bacias hidrográficas e amostras circulares de redes de drenagem de solos com horizonte B textural. Piracicaba, 1977. 126p. (Doutorado - Escola Superior de Agricultura "Luiz de Queiroz"/USP).

CARVALHO, W.A.; PIEDADE, G.C.R.; CARVALHO, A.M.; DENADAI, I.M. Relação entre distribuição de solos e semelhança geométrica de bacias de drenagem no Município de Botucatu. Rev. Bras. Ciên. Solo, Campinas, 4(2):110-14, 1980.

CARVALHO, W.A. Relações entre relevo e solos da bacia do Rio Capivara, Município de Botucatu, SP. Botucatu, 1981. 193p. (Livre-Docência - Faculdade de Ciências Agronômicas/UNESP).

CARVALHO, W.A.; FRANÇA, G.V.; CURI, P.R. Aplicação de análise multivariada na discriminação de unidade de solo, mediante parâmetros morfométricos de bacias hidrográficas, em Btucatu, SP. Rev. Bras. Ciên. Solo, Campinas, 14(2):195-203, 1990.

CHRISTOFOLETTI, A. Geomorfologia. São Paulo, EDUSP, 148p, 1974.

CHRISTOFOLETTI, A. \& CESAR, A.L. Correlação entre densidade de drenagem e comprimento médio de canais em bacias hidrográficas. Ciência e Cultura, São Paulo, 5:601-04, 1978. 
COCHRANE, G.R. \& BROWNE, G.H. Geomorphic mapping from Landsat-3 Return Beam Vidicon (RBV) imagery. Photogrammetric Engineering, Falls Church, 47(8):1205-13, 1981 .

COELHO, A.G. de S. Ecologia e potencial de estudos com base nas modernas técnicas de sensoriamento remoto. Aerofotografia, São Paulo, I.G./USP, 11:01-44, 1972.

COLWELL, R.N. Photographic interpretation for civil purposes. In: American Society of Photogrammetry. Manual of Photogrammetry, 2.ed., Washington, 1952. p.535-602.

COVRE, M.; RIEDEL, P.S.; EPIPHANIO, J.C.N. Análise quantitativa da drenagem através de imagens TM/Landsat e fotografias aéreas. In: SIMPÓSIO LATINOAMERICANO (SIMPÓSIO BRASILEIRO, 4.) DE SENSORIAMENTO REMOTO, Gramado, 1986. Anais. São José dos Campos, SELPER/INPE/SBC, 1986. p.280. (Resumo).

CREPANI, E. Princípios básicos de sensoriamento remoto. São José dos Campos, INPE, 45p. 1983. 
CRESWICK, W.J. \& ROCKWELL, W.H. Applications of aerial photographic techniques to agricultural surviveys. In: Aerial Photographic Interpretation: Principle and Applications. Mac-Graw-Hill Book Co. Inc. New York, p.373-85, 1959.

CURTIS, L.F.; DOORNKAMP, J.C.; GREGORY, K.J. The description of relief in field studies of soil. Jour. Soil. Sci, Oxford, 16:16-30, 1965.

DE GRANDE, D.A. \& LOPES, E.A. Plantas da restinga da Ilha do Cardoso (São Paulo - Brasil). Hoehnea, São Paulo, 9:1-22, 1981.

DEMÉTRIO, V.A. Variação de características de redes de drenagem em função da escala das fotografias aéreas verticais. Piracicaba, 1977. 107p. (Mestrado - Escola Superior de Agricultura "Luiz de Queiroz"/USP).

DOMINGUES, E.N. Estudo de processos geomorfológicos do escoamento fluvial e evolução de vertentes na Serra de Cubatão, Serra do Mar, SP. São Paulo, 1983, 153p. (Mestrado - Faculdade de Filosofia, Ciências e Letras/USP).

DONZELI, P.L.; VALÉRIO FILHO, M.; PEREZ FILHO, A.; NOGUEIRA, F.P.; KOFFLER, N.F. Imagens orbitais e de radar na definição de padrões fisiográficos aplicados a solos. Rev. Bras. Ciên. Solo, Campinas, 7(1):89-94, 1983. 
DU TOIT, S.H.C.; STEYN, A.G.W.; STUMPF, R.H. Cluster analysis. In: Graphical exploratory data analysis. New York, Springer-Verlag. New York Inc., 1986. cap.5, p.73-104.

EGAN, W.G. \& HALLOC, H.B. Polarimetry signature of terrastrial and planetary materials. Proceedings of the Fourth Symposium on Remote Sensing of Environment Infrared Physics Laboratories. The Institute of Science and Technology. The University of Michigan, Ann Arbor, p.671-89, 1966.

EPIPHANIO, J.C.N.; FORMAGGIO, A.R.; VALÉRIO FILHO, M. Imagens RBV/Landsat-3 em estudos da rede de drenagem. In: SIMPÓSIO BRASILEIRO DE SENSORIAMENTO REMOTO, 2., Brasília, 1983. Anais. São José dos Campos, INPE/CNPq, 1983, v.1, p.285-92.

ESPÍNDOLA, C.R. Relações entre solos e elementos da paisagem na zona do baixo Rio do Peixe (Região de Conchas - Anhembi, SP). Piracicaba, 1977. 113p. (Mestrado - Escola Superior de Agricultura "Luiz de Queiroz"/USP).

FADEL, H. Fotointerpretação de bacias e de redes de drenagem de três séries de solos da Fazenda Ipanema, Município de Araçoiaba da Serra (SP). Piracicaba, 1972. 92p. (Mestrado - Escola Superior de Agricultura "Luiz de Queiroz"/USP). 
FAGUNDES, P.M. Estudo comparativo das extensas coberturas de imagens disponíveis no Brasil. Aerofotogeografia, São Paulo, IG/USP, 24:1-13, 1976.

FAUCK, R.; LAMOUROUX, M.; PERRAUD, A.; QUANTIN, P.; ROEDERER, P.; VIELlefon, J.; SEGALEN, P. Project de classification des sols. Services Cientifiques Centraux, Orston, 1979. 301p.

FRANÇA, G.V. de. Interpretação fotográfica de bacias e redes de drenagem aplicada a solos da região de Piracicaba. Piracicaba, 1968. 151p. (Doutorado - Escola Superior de Agricultura "Luiz de Queiroz"/USP).

FREIRE, J.C. Fotointerpretação de redes de drenagem de três solos da região de Altinópolis, Minas Gerais. Piracicaba, 1977. 136p. (Doutorado - Escola Superior de Agricultura "Luiz de Queiroz"/USP).

FREITAS, R.O. de. Ensaio sobre a tectônica moderna do Brasil. Bol. Fac. Fil. Ci. e Letras, São Paulo, (130):1-120, 1951. (Geologia, 6).

FROST, R.E. Photointerpretation of soils. In: American Society of Photogrammetry. Manual of Photogrammetry, Washington, 1960. cap.5, p.343-402. 
GARCIA, G.J. Fotointerpretação comparativa de fotografias pancromáticas, coloridas e infravermelhas coloridas (falsa cor). Piracicaba, 1975. 111 p. (Doutorado - Escola Superior de Agricultura "Luiz de Queiroz"/USP).

GARCIA, G.J. Técnicas de sensoriamento remoto na avaliação do potencial de uso de regiões de cerrado. Botucatu, 1979. 135p. (Livre-Docência - Faculdade de Ciências Agronômicas//UNESP).

GARCIA, G.J.; NORTON, L.D.; ESPINDOLA, C.R. Fotointerpretação comparativa de fotografias pancromáticas, imagens de radar e de satélite. Científica, Botucatu, 9(1):37-43, 1981 .

GEVAERD, I. Parâmetros fotoanalíticos de três unidades de solo da região nordeste paranaense. Piracicaba, 1974. 110p. (Mestrado - Escola Superior de Agricultura "Luiz de Queiroz"/USP).

GEVAERD, I. Identificação dos fatores determinantes das características placohipsométricas de três unidades de solo da região nordeste paranaense. Piracicaba, 1976. 63p. (Doutorado - Escola Superior de Agricultura "Luiz de Queiroz"/USP). 
GIMBARZEVSKY, P. ERTS-1 images in biophysical studies. In:. CANADIAN SYMPOSIUM ON REMOTE SENSING, 2., Guelph, 1974. Proceedings. Ottawa, Departament of Energy, Mines and Resources, 1974a, v.2, p.391-403.

GIMBARZEVSKY, P. The significance of topographic relief in air photo analysis of Landscape pattern. SYMPOSIUM OF REMOTE SENSING AND PHOTOINTERPRETATION, Alberta, 1974. Proceedings. Alberta, International Society of Photogrammetry, 1974b, p.165-76.

GOMES, F.P. Curso de Estatística Experimental. Piracicaba, ESALQ/USP. 467p. 1987. (12 ed.)

GOOSEN, D. Aerial photo interpretation in soil survey. Roma, Food and Agriculture Organization of the United Nations, 1967. 55p. (Soil Bulletin, 6).

GOOSEN, D. Interpretation de fotos aéreas y su importancia en levantamiento de suelos. Organización de Las Naciones Unidas para la Agricultura y la Alimentación. Roma, 1968. 58p. (Bol. sobre Suelos, 6).

GUIMARÃES, M.F. Relação entre relevo e solos provenientes de rochas eruptivas básicas. Piracicaba, 1984. 101p. (Mestrado - Escola Superior de Agricultura "Luiz de Queiroz"/USP). 
GUNN, R.H. The use of aerial photography in soil survey and mapping in the Sudan. Soil Fertil., Harpenden, 18:104-6, 1955.

HORTON, R.E. Erosional development of streams and their drainage basins: hidropysical approach to quantitative morphology. Bulletin of the Geological Society of America, Colorado, 56:275-370, 1945

HOWE, R.H.L. The application of aerial photographic interpretation to the investigation of hidrology problems. Photogrammetric Engineering, Falls Church, 26:85-95, 1960.

KOFFLER, N.F. Utilização de imagens aerofotográficas e orbitais no estudo do padrão de drenagem em solos originados do arenito bauru. São José dos Campos, 1976a. 167p. (Mestrado - Instituto de Pesquisas Espaciais).

KOFFLER, N.F. Análise aerofotográfica da influência da área de amostragem circular na caracterização quantitativa do padrão de drenagem. José dos Campos, 1976b. 20p. (INPE 974 - NTE/074).

KOFFLER, N.F. Análise do relevo a partir de índices de drenagem obtidos com fotografias aéreas. Bol. Geografia Teorética, Rio Claro, 12(23/24):69-76, 1982. 
KOOPMANS, B.N. Drainage analysis on radar images. ITC Journal, 3:464-69, 1973.

LEÃO, S.R.F. Interpretação fotográfica dos padrões de drenagem desenvolvida em dois solos do Distrito Federal. Piracicaba, 1972. 110p. (Mestrado - Escola Superior de Agricultura "Luiz de Queiroz"/USP).

LEÃO, S.R.F. Interpretação fotográfica de características do relevo e da drenagem em dois solos do Distrito Federal. Piracicaba, 1983. 166p. (Doutorado - Escola Superior de Agricultura "Luiz de Queiroz"/USP).

LUEDER, D.R. Aerial photographic interpretation: principles and applications. New York, McGraw-Hill, 1959. 462p.

LYON, R.J.P.; MERCADO, J.; CAMPBELL JÚNIOR, R. Pseudo radar very hight contrast aerial photography at low Sun-Angles. Photogrammetric Engineering, Falls Church, 36(12):1257-61, 1970.

MANECHINI, C. Utilização de fotografias aéreas na comparação de sistemas de drenagem de três solos da região de Tambaú-SP. Piracicaba, 1981. 133p. (Mestrado - Escola Superior de Agricultura "Luiz de Queiroz"/USP). 
MARCHETTI, D.A.B. Fotointerpretação de atributos de relevo aplicada a solos da região de Piracicaba. Piracicaba, 1969. 58p. (Doutorado - Escola Superior de Agricultura "Luiz de Queiroz"/USP).

MARCHETTI, D.A.B. \& GARCIA, G.J. Mapeamento de solos através do caráter espectral, da rede de drenagem e da vegetação. Anais da Escola Superior de Agricultura "Luiz de Queiroz", Piracicaba, 47(pt.1):193-220, 1990.

MARCOS, Z.Z. \& KINJO, T. Litosol suas características e provável gênese. Anais da Escola Superior de Agricultura "Luiz de Queiroz", Piracicaba, 24:343-52, 1967.

MARQUES, J.Q.A. Manual brasileiro para levantamento da capacidade de uso da terra. Rio de Janeiro, Escritório Técnico Brasil-Estados Unidos, 1971. 433p.

MAXWELL, J.C. The bifurcation ratio in Horton's law of stream numbers (abstract). Trans. Amer. Geophys. Union, New Haven, 36:520, 1955. (Resumo).

MEUNIER, A. \& TALTASSE, P. Caractére subsident de certains "tabuleiros" de la côte orientale du Brésil. Comptes rendus des séances de l'Academie des Sciences, Paris, t.247:1885-86, 1958. 
MONTEIRO, M.F. \& SILVA, T.C. Aspectos fluviais importantes para a fotointerpretação. 2.ed. Salvador(BA), Universidade Federal da Bahia, 1979. 44p.

MONTOYA, J.A. Comparación de interpretaciones fisiográficas de imágenes Landsat, radar y fotografias aéreas para una zona de los Llanos Orientales de Colombia. Rev. CIAF, Bogotá, 4(1):83-9, 1977.

MONTOYA, J.A. Interpretación de imagens Landsat para el mapeo de suelos; bases para una metodologia. Rev. CIAF, Bogotá, 8(1):201-33, 1983.

MOORE, R.K. \& SIMONETT, D.S. Potential research and earth resources studies with orbiting radars: results of recent studies. University of Kansas, Center for Research in Engineering Science, Report n⿳0 61-32, 21p, 1967.

MORAIN, S.A. \& SIMONETT, D.S. Vegetation analysis with radar imagery. University of Kansas, Center for Research in Engineering Science, Report n ${ }^{0}$ 61-9, $18 \mathrm{p}, 1966$.

NOFFS, M. da S. \& BAPTISTA-NOFFS, L.J. Mapa da vegetação do Parque Estadual da Ilha do Cardoso - As principais formações. In: CONGRESSO NACIONAL SOBRE ESSÊNCIAS NATIVAS, Campos do Jordão (SP), 1982. Silvic. SP., São Paulo, 16A(1):620-28, 1982. 
NOGUEIRA, F.P. Utilização de fotografias aéreas em três escalas no estudo de redes de drenagem em diferentes unidades de solo. Piracicaba, 1979. 110p. (Mestrado Escola Superior de Agricultura "Luiz de Queiroz"/USP).

NOVO, E.M.L.M. Efeito do ângulo de elevação solar e do azimute na determinação de compartimentos geomorfológicos. In: SIMPÓSIO BRASILEIRO DE SENSORIAMENTO REMOTO, 2., Brasília, 1983. Anais. São José dos Campos, INPE/CNPq, 1983, v.1, p.53-66.

NUNNALY, N.R. Integrated landscape analysys with radar imagery. Remote Sensing of Environment, (1):1-6, 1969.

PACHECO, R.A. \& HOWARD, J.A. Application of satellite remote sensing to landscapes and soils. In: SOIL SURVEY REMOTE SENSING, 1., Roma, 1977. Proceedings. Roma, 1977. p.159-72.

PARRY, J.T. X-Band radar in terrain analysis under summer and winter conditions. In: CANADIAN SYMPOSIUM ON REMOTE SENSING, 2., Guelph, ON, 1974. Proceedings. Ottawa, Department of Energy, Mines and Resources, 1974. v.2, p.472-85. 
PARVIS, M. Drainage-pattern significance in airphoto identification of soils and bedrocks. Photogrammetric Engineering, Falls Church, 16(3):387-408, 1950.

PASTO, F.K. Soil mapping by stereoscopic interpretation of airphotos. Soil Sci. Soc. Am. Proc., Madison, 17:135-38, 1953.

PETRI, S. \& SUGUIO, K. Sobre os metassedimentos do Grupo Açungui do extremo sul do Estado de São Paulo. Convênio DAEE-USP, Secretaria dos Serviços e Obras Públicas. Universidade de São Paulo, São Paulo, 81p., 13 fig., 8 fotos. 1969.

PETRI, S. \& FÚLFARO, V.J. Nota sobre a geologia e terraços marinhos da Ilha do Cardoso, SP. Not. Geomorf., Campinas, 10(20):21-32, 1970.

PFEIFER, R.M. Levantamento semidetalhado dos solos do Parque Estadual da Ilha do Cardoso, SP. Silvic. S.Paulo, São Paulo, 15/16:91-115, 1981/82.

PFEIFER, R.M. Fotointerpretação de bacias hidrográficas e amostras circulares de redes de drenagem dos solos do Parque Estadual da Ilha do Cardoso (SP). Piracicaba, 1984. 90p. (Mestrado - Escola Superior de Agricultura "Luiz de Queiroz"/USP). 
PFEIFER, R.M. \& DOMINGUES, E.N. Caracterização geomorfológica e das formações superficiais das Escarpas do P.E. da Ilha do Cardoso (SP). Silvic. S.Paulo, São Paulo, 17/18:47-51, 1983/85.

PFEIFER, R.M.; NOFFS, M. da S.; SILVA, D.A. Correlação de características do meio biofísico do P.E. da Ilha do Cardoso (SP). Rev. Inst. Flor., São Paulo, 1(1):39-49, 1989.

PIEDADE, G.R.C. Evolução de voçorocas em bacias hidrográficas do Município de Botucatu, SP. Botucatu, 1980. 161p. (Livre-Docência - Faculdade de Ciências Agronômicas, UNESP).

POLITANO, W. Estudo fotointerpretativo sobre a morfometria das áreas de dois solos Podzólicos Vermelho-Amarelos. Piracicaba, 1980. 169p. (Doutorado - Escola Superior de Agricultura "Luiz de Queiroz"/USP).

QUACKENBUSH, R.S. Development of photo interpretation. In: American Society of Photogrammetry. Manual of Photography Interpretation, Washington, 1960. cap.1, p.1-18. 
RABBEN, E.L. Fundamentals of photo interpretation. In: American Society of Photogrammetry. Manual of Photography Interpretation, Washington, 1960. cap.3, p.99-168.

RADAMBRASIL. Ministério das Minas e Energia. Levantamento de Recursos Naturais. Folhas SF 23/24. Rio de Janeiro/Vitória. Rio de Janeiro, vol. 32, 780p. 1983.

RAY, R.G. \& FISCHER, W.A. Quantitative photography: a geologic research tool. Photogrammetric Engineering, Falls Church, 26(1):143-50, 1960.

RAY, R.G. Fotografias aéreas na interpretação e mapeamento geológicos. Trad. por J. Felicíssimo Jr. Inst. Geogr. e Geol. São Paulo, 1963. 88p. (75 fotogramas).

RICCI, M. \& PETRI, S. Princípios de Aerofotogrametria e Interpretação Geológica, São Paulo, Ed. Nacional, 88p. 1965.

ROCHA, J.S.M. Estudo dos padrões ou sistemas de drenagens; Abastecimento de água para núcleos rurais e cidades. Santa Maria, UFSM, 1986. 47p. (Manual de Interpretação de Aerofotogramas, 13). 
ROMESBURG, H.C. Cluster analysis for researchers. California, Lifetime Learning Publications, 1984. 334p.

ROUDABUSCH, R.D.; HERRIMAN, R.C.; BARMORE, R.L.; SCHELLENTRAGER, G.W. Use of Landsat Multispectral Scanning data for soil surveys on Arizona Rangeland. Journal of Soil and Water Conservation, Utah, 40(2):242-5, 1985.

ROURKE, J.D. \& AUSTIN, M.E. The use of airphotos for soil classification and mapping in the field. Photogrammetric Engineering, Falls Church, 17:738-41, 1951.

ROUSE, J.W.; WAITE, W.P.; WALTERS, R.L. Use of orbital radars for geoscience investigations. University of Kansas, Center for Research in Engineering Science, Report no 61-8, 31p, 1965.

SAS Institute Inc. SAS/STAT Guide for Personal Computers. Version 6 Edition. Cary, NC, SAS Institute Inc., 1987. 1028p.

SCHUMM, S.A. Evolution of Drainage Systems and Slopes in Badlands and Perth Ambry, New Jersey. Bull. Geol. Soc. Amer., Boulder, v.67, p.597-646, 1956. 
SEGALEN, P. Les produits alumineux dans les sols de la zone tropicale humids; les produits alumineux. Cah. Orston, Paris, 3:149-76, 1965. (Série Pedologia).

SEGOVIA, A.V.; FOSS, J.E.; SOLER, E.A. Evaluation of soils and Landscapes of the seasonal ropics by means of remote sensing images: an interdisciplinary study. In: INTERNATIONAL SYMPOSIUM ON REMOTE SENSING OF ENVIRONMENT, 14., San Jose, 1980. Proceedings. Ann Arbor, MI, ERIM, 1980. v.2, p.913-28.

SIEGAL, B.S. \& GOETZ, A.F.H. Effect of vegetation on rock and soil type discrimination. Photogrammetric Engineering and Remote Sensing, Falls Church, 43(2):191-6, 1977.

SILVA, M.S. Fotointerpretação da rede de drenagem e do relevo de três solos do município de São Manuel, SP. Botucatu, 1988. 163p. (Doutorado - Faculdade de Ciências Agronômicas/UNESP).

SIMONS, J.H. Some applications of Side-Looking Airborner Radar. In: SYMPOSIUM ON REMOTE SENSING OF ENVIRONMENT, 3., Ann Arbor, MI, 1964. Proceedings. Ann Arbor, MI, ERIM, 1964. v.1, p.563-71. 
SMITH, H.T.V. Aerial Photographs and their Applications. New York, D. Appleton-Century Co. 1943, 372p.

SMITH, K.S. Standards for grading texture of erosional topography. American Journal of Science, (248):655-68, 1950.

SOIL SURVEY STAFF. Soil Survey Manual. Washington, D.C., USDA, 1951. 503p. (Handbook, 18).

SOUZA, M.L.P. Fotointerpretação das redes de drenagem de três solos com horizonte B latossólico ocorrentes no município de Ponta Grossa (PR). Piracicaba, 1975. 135p. (Mestrado - Escola Superior de Agricultura "Luiz de Queiroz"/USP).

STRAHLER, A.N. Hypsometric (área - altitude) analysis of erosional topography. Bull. Geol. Soc. Amer., 63:1117-42, 1952.

STRAHLER, A.N. Quantitative analysis of watershed geomorphology. Trans. Am. Geophys. Union., New Haven, 38:913-20, 1957.

SUDELPA - SUPERINTENDÊNCIA DO DESENVOLVIMENTO DO LITORAL PAULISTA. Relatório final; geomorfologia. São Paulo, CPRN-SEPLAN, 1975. v. $12,707 p$. 
SUMMERSON, C.H. A phylosophie for photointerpretation. Photogrammetry Engineering, Falls Church, 20:396-7, 1954.

TATOR, B.A. Drainage annomalies in Coastal Plains Regions. Photogrammetric Engineering, Falls Church, 20:412-17, 1954.

THE AMERICAN SOCIETY OF PHOTOGRAMMETRY. Manual of Photogrammetry. Menasha, Wisconsin, The Georgia Banta Company, Inc., 1966. v.I e II, ix 1199p.

THORNBURY, W.D. Principles of geomorphology, New York, John Wiley \& Sons, Inc., 1954. 618p.

ThORnthWaite, C.W. \& MATHER, J.R. The water balance. Pubs. Clim. Drexel, Technol. Inst., Centerton, N.J., 8(1):1-104, 1955.

TOWNSHEND, J.R.; WILLIANS, D.F.; JUSTICE, C.O. An evaluation of Landsat-3 RBV imagery for an area of complex terrain in southern Italy. In: INTERNATIONAL SYMPOSIUM ON REMOTE SENSING ${ }^{\circ}$ OF ENVIRONMENT, 13., Ann Arbor, MI, 1979. Proceedings. Ann Arbor, MI, ERIM, 1979. v.3, p.1839-52. 
VALERIO FILHO, M.; HIGA, N.T.; CARVALHO, V.C. Avaliação das imagens orbitais (Landsat-1) como base para o levantamento de solos. São José dos Campos, 1976. 276p. (Mestrado - Instituto de Pesquisas Espaciais).

VALERIO FILHO, M.; EPIPHANIO, J.C.N.; FORMAGGIO, A.R. Metodologia de interpretação de dados de sensoriamento remoto e aplicações em pedologia. São José dos Campos, INPE/CNPq, 1981. 58p. (INPE-2211 - MD/008).

VALERIO FILHO, M. Parâmetros da drenagem e do relevo na caracterização de solos e suas relações fotointerpretativas em imagens de pequena escala. Piracicaba, 1984. 141p. (Doutorado - Escola Superior de Agricultura "Luiz de Queiroz"/USP).

VASQUES FILHO, J. Critérios morfométricos aplicados à fotointerpretação de redes de drenagem em três unidades de solos no município de Piracicaba. Piracicaba, 1972. 113p. (Doutorado - Escola Superior de Agricultura "Luiz de Queiroz"/USP).

VERA, L. Tecnicas de inventário de la tierra agrícola: el proyecto aerofotogramétrico. OEA/Chile. Washington, Union Panamericana, 1964. 136p. (Manuales técnicos, $\mathrm{X})$. 
VETTORAZZI, C.A. Fotointerpretação de bacias hidrográficas e redes de drenagem em cinco solos da região do rio Ribeira de Iguape no Estado de São Paulo. Piracicaba, 1985. 151p. (Mestrado - Escola Superior de Agricultura "Luiz de Queiroz"/USP).

VETTORAZZI, C.A. Interpretação de imagens TM/Landsat-5, em duas escalas, na caracterização fisiográfica para mapeamento de solos. Piracicaba, 1988. 184p. (Doutorado - Escola Superior de Agricultura "Luiz de Queiroz"/USP).

VETTORAZZI, C.A.; ANGULO FILHO, R.; KOFFLER, N.F. Análise de áreas com diferentes classes de declividade através de imagens TM/Landsat. Anais da Escola Superior de Agricultura "Luiz de Queiroz", Piracicaba, 44(2):1579-606, 1987.

VON ENGELN, O.D. Geomorphology: systematical and regional. New York, The Mc Millan Company, 1942. 655p.

WALKER, P.M. \& TREXLER, D.T. Low sun-angle photography. Photogrammetric Engineering and Remote Sensing, Falls Church, 43(4):493-506, 1977. 
WESTIN, F.C. ERTS-1 MSS imagery: its use in delineating soil associations and as a base map for publishing soil informations. In: EARTH RESOURCES TECHNOLOGY SATELLITE SYMPOSIUM, 3., Washington, D.C. 1973. Proceedings. Washington, D.C., NASA, 1973. v.1, p.183-204.

WESTIN, F.C. \& FRAZEE, C.J. Landsat data: its use in a soil survey program. Soil Sci. Soc. Am. J., Baltimore, 40(1):81-9, 1976.

WESTIN, F.C. \& BRANDNER, T.M. Use of Landsat data in soil and agricultural land use studies. In: INTERNATIONAL SYMPOSIUM ON REMOTE SENSING OF ENVIRONMENT, 14., San Jose, 1980. Proceedings. Ann Arbor, MI, ERIM, 1980. v.1, p.389-400.

WONG, K.W.; THORNBURN, T.H.; KHOURY, M.A. Automatic soil identification from remote sensing data. Photogrammetric Engineering and Remote Sensing, Falls Church, 43(1):73-80, 1977.

YOUNG, A. Tropical Soils and Soil Survey. Cambridge, Cambridge University Press, 1976. 468p.

ZINKE, P.J. Photo interpretation in hidrology and watershed management. In: Manual of photographic interpretation, Washington, American Society of Photogrammetry, 1960. cap.10, p.539-60. 
203

APÊNDICE 


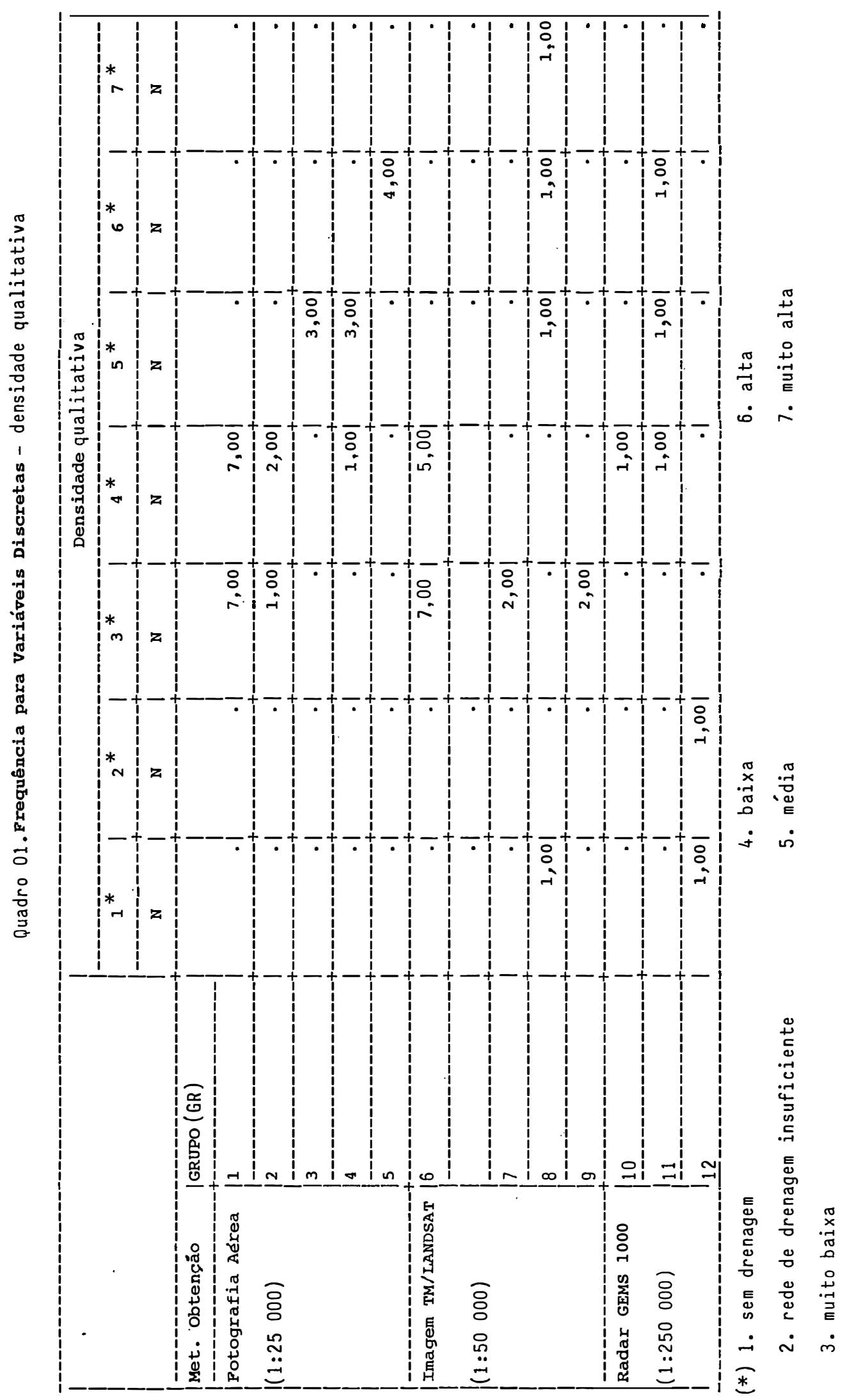




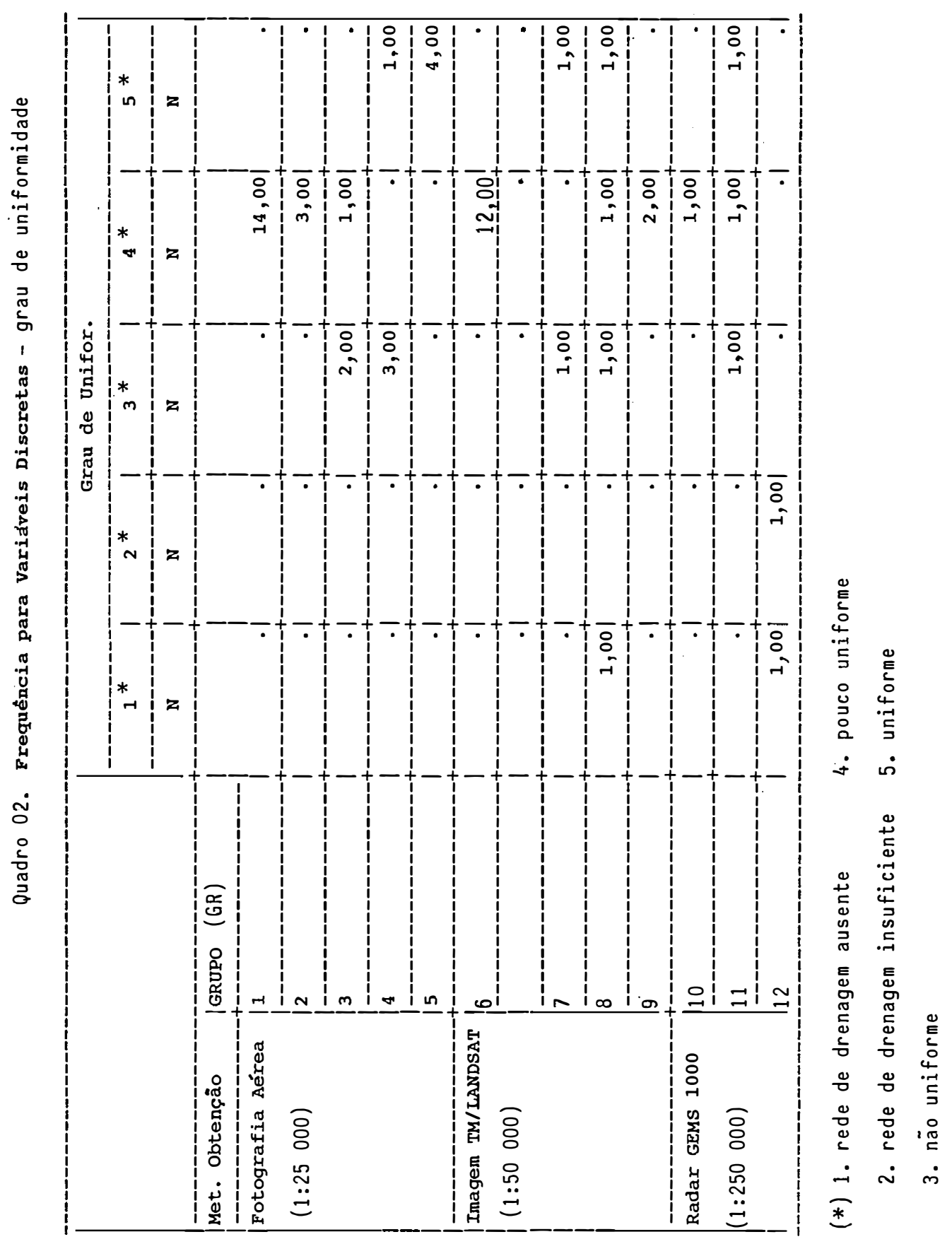




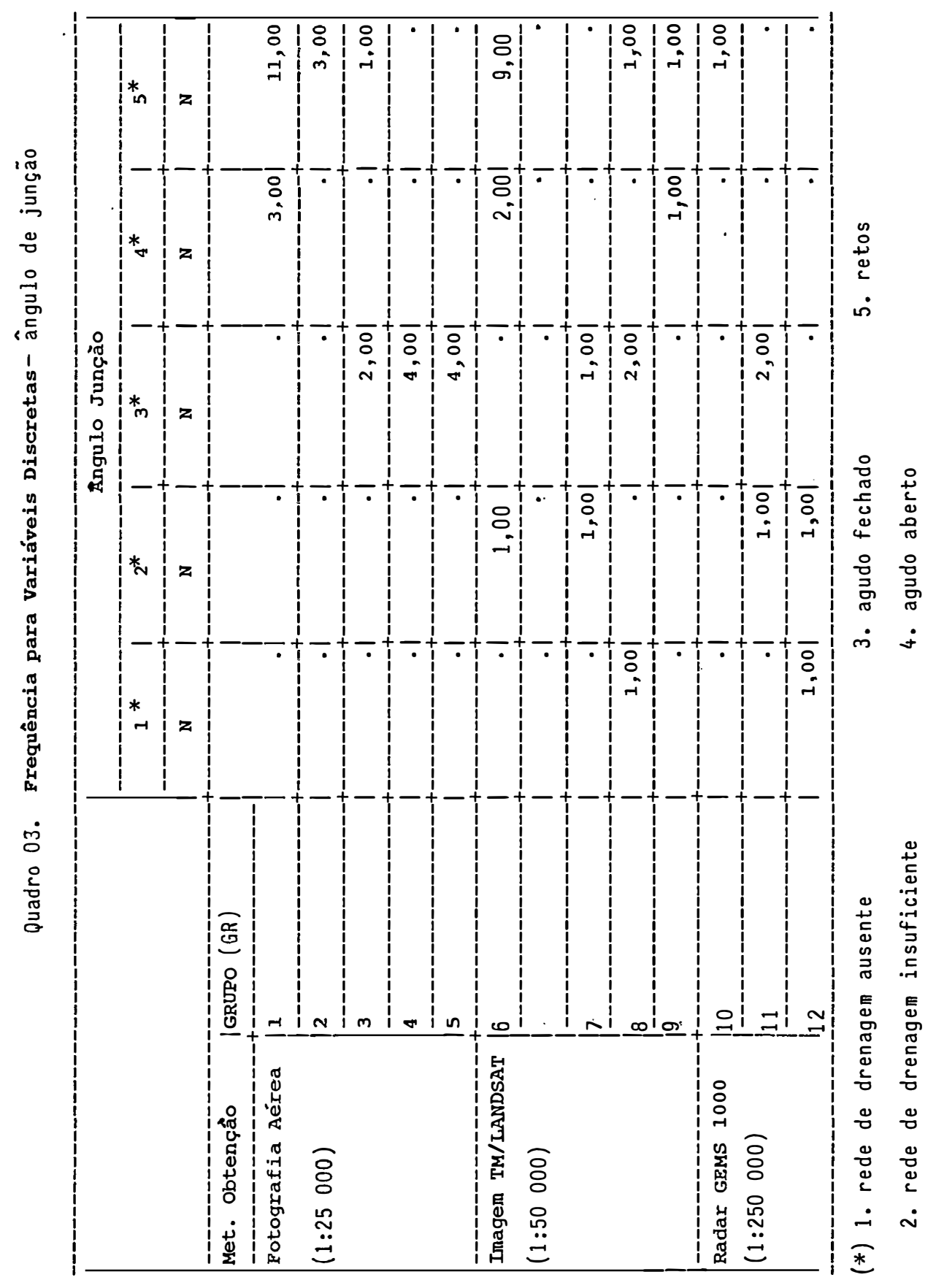




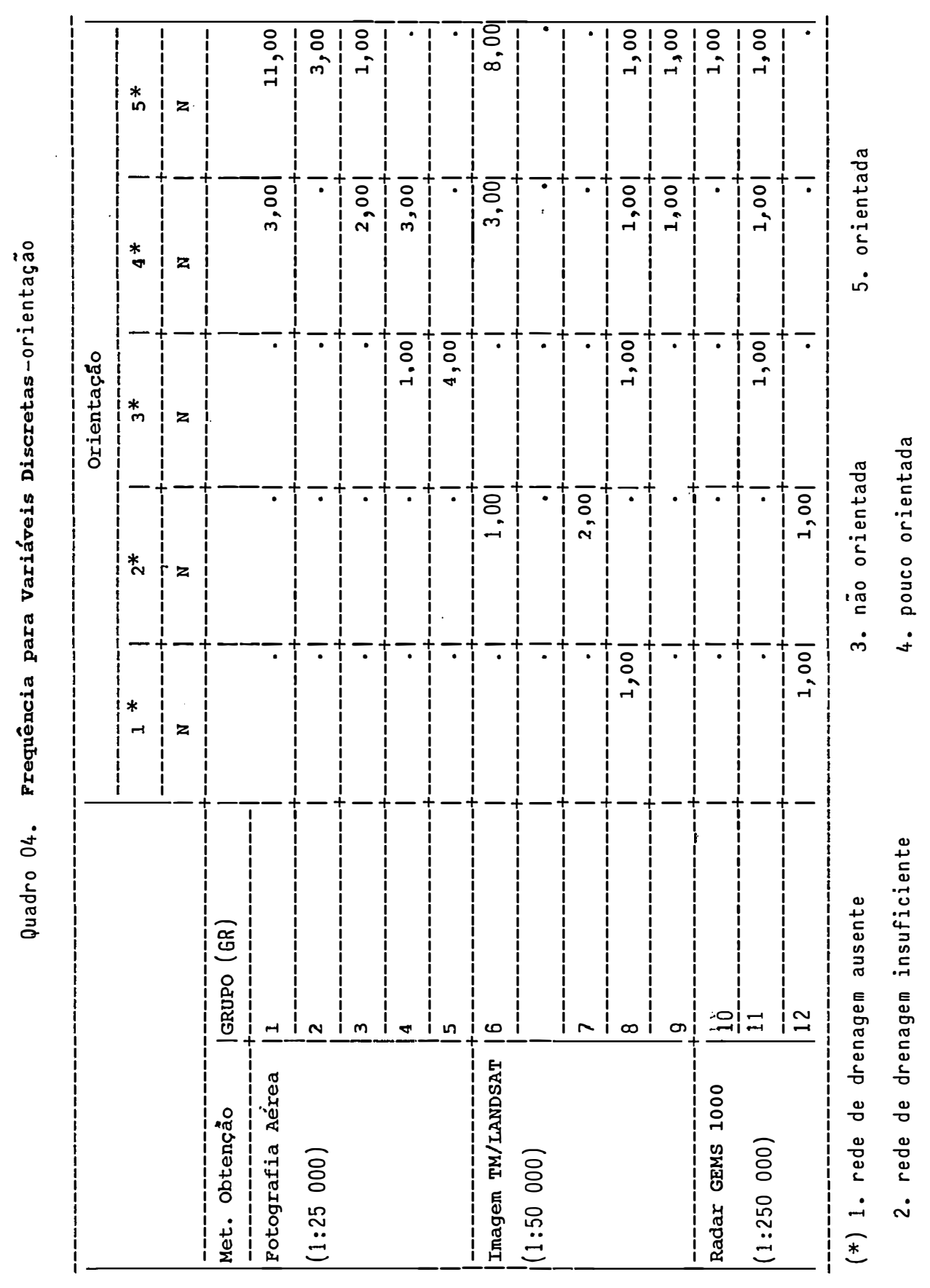




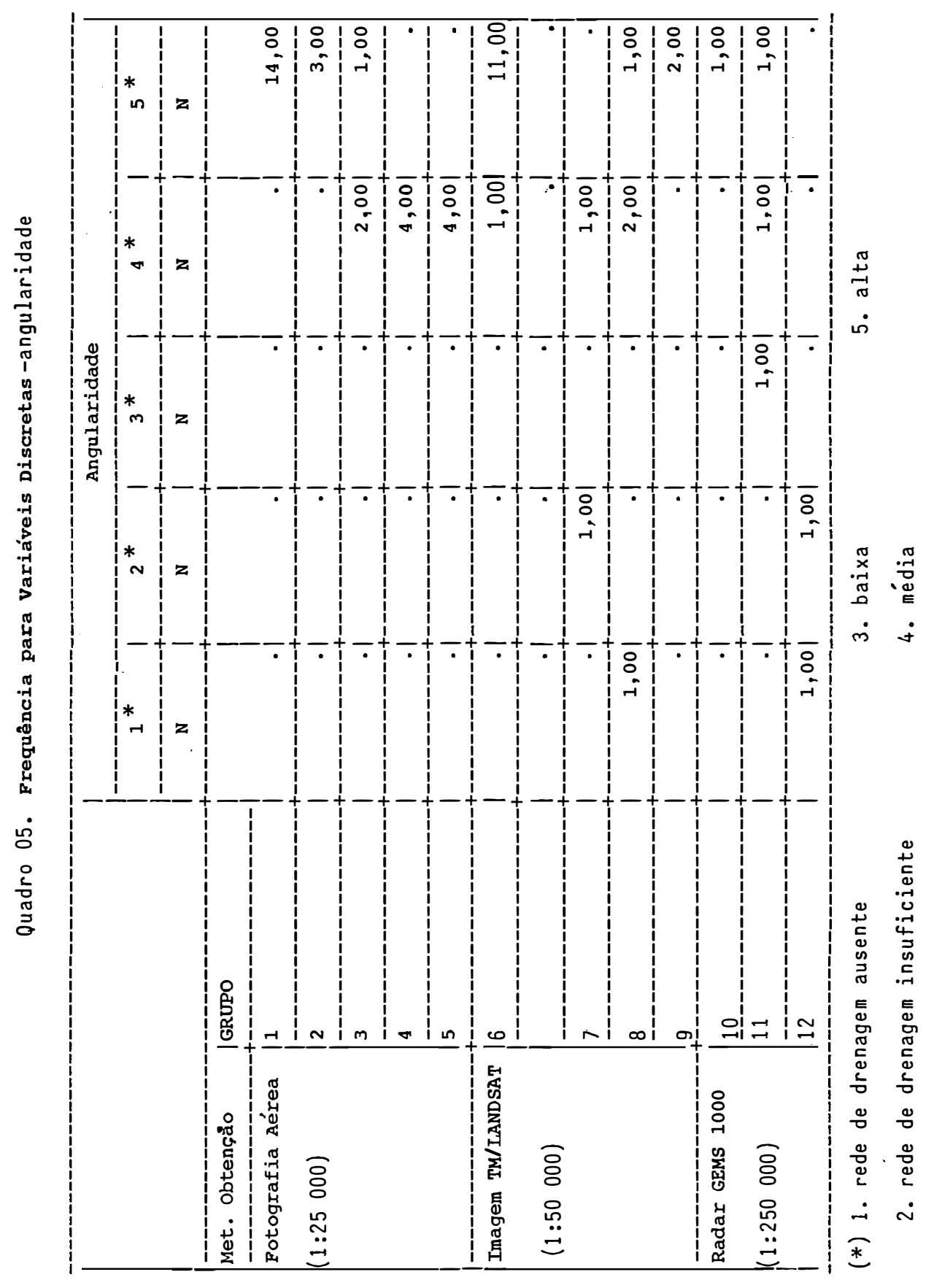




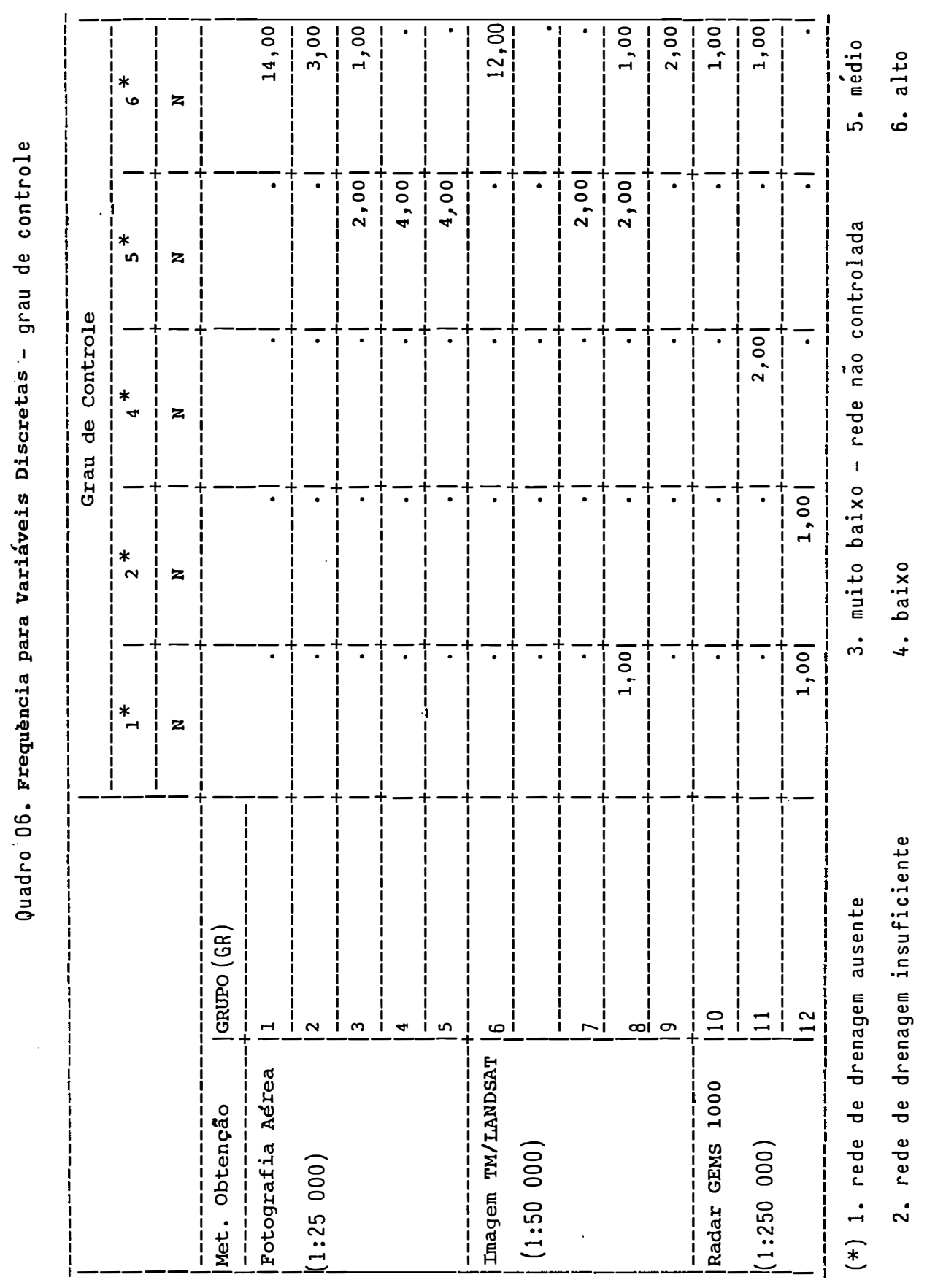




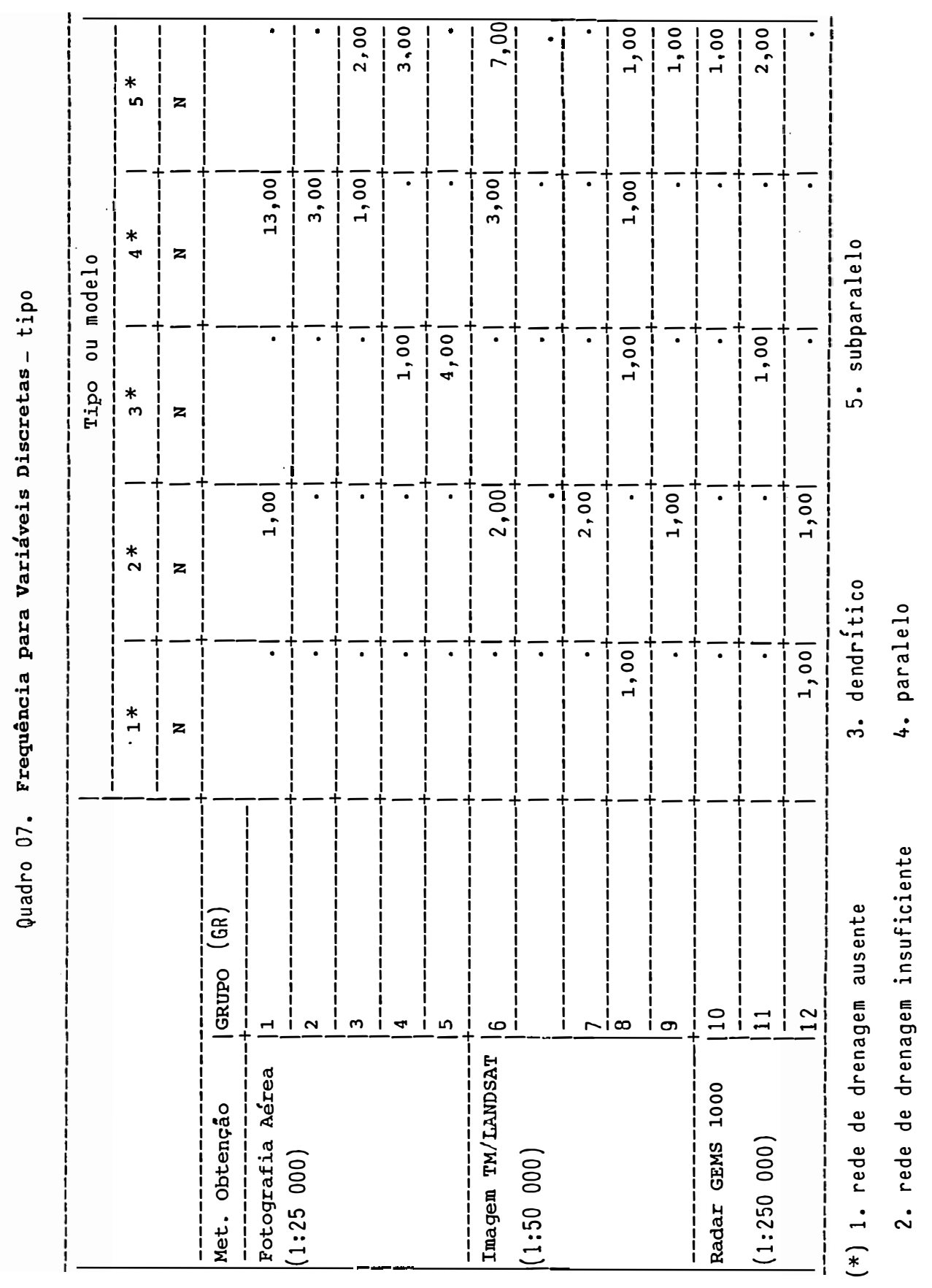




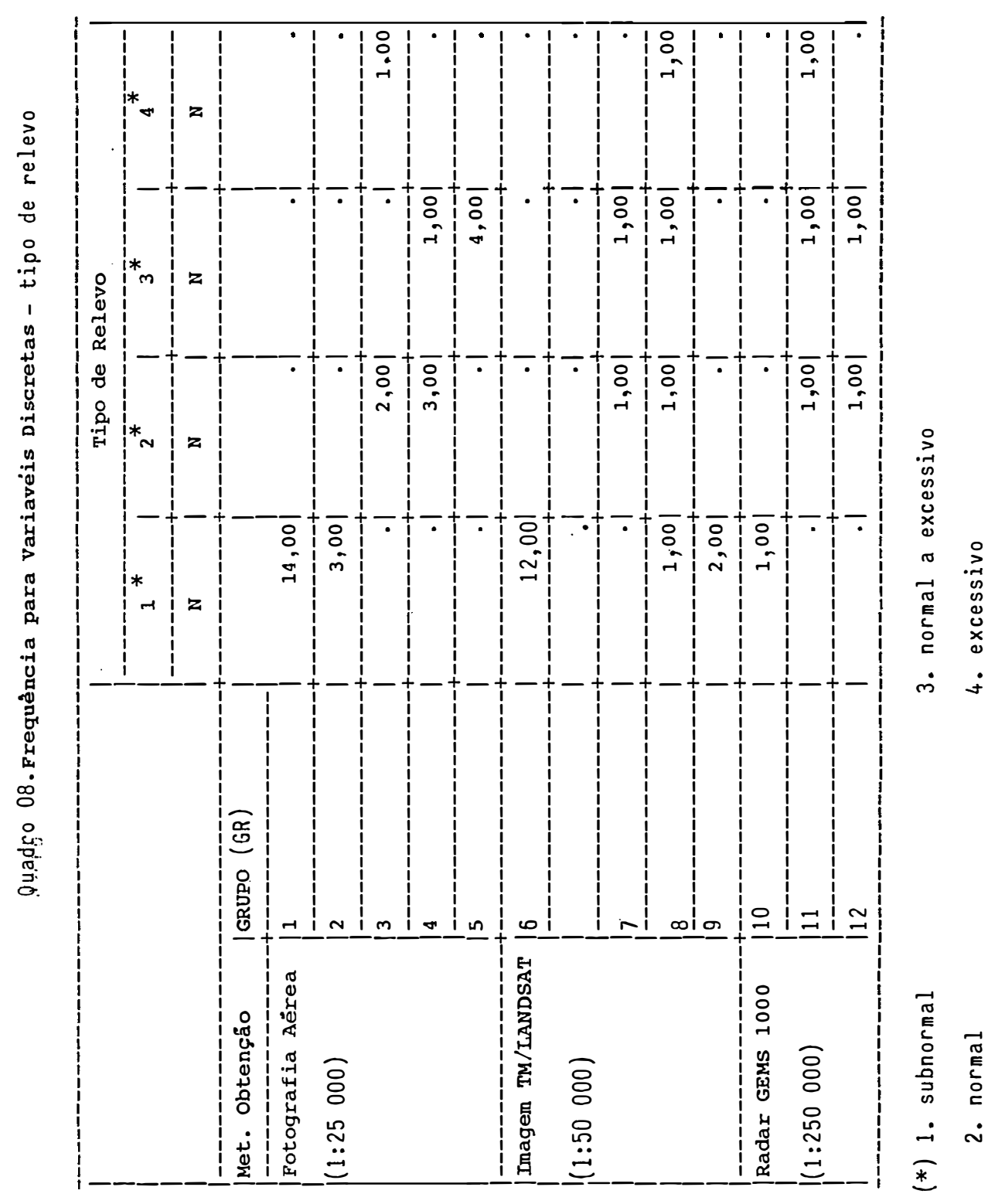




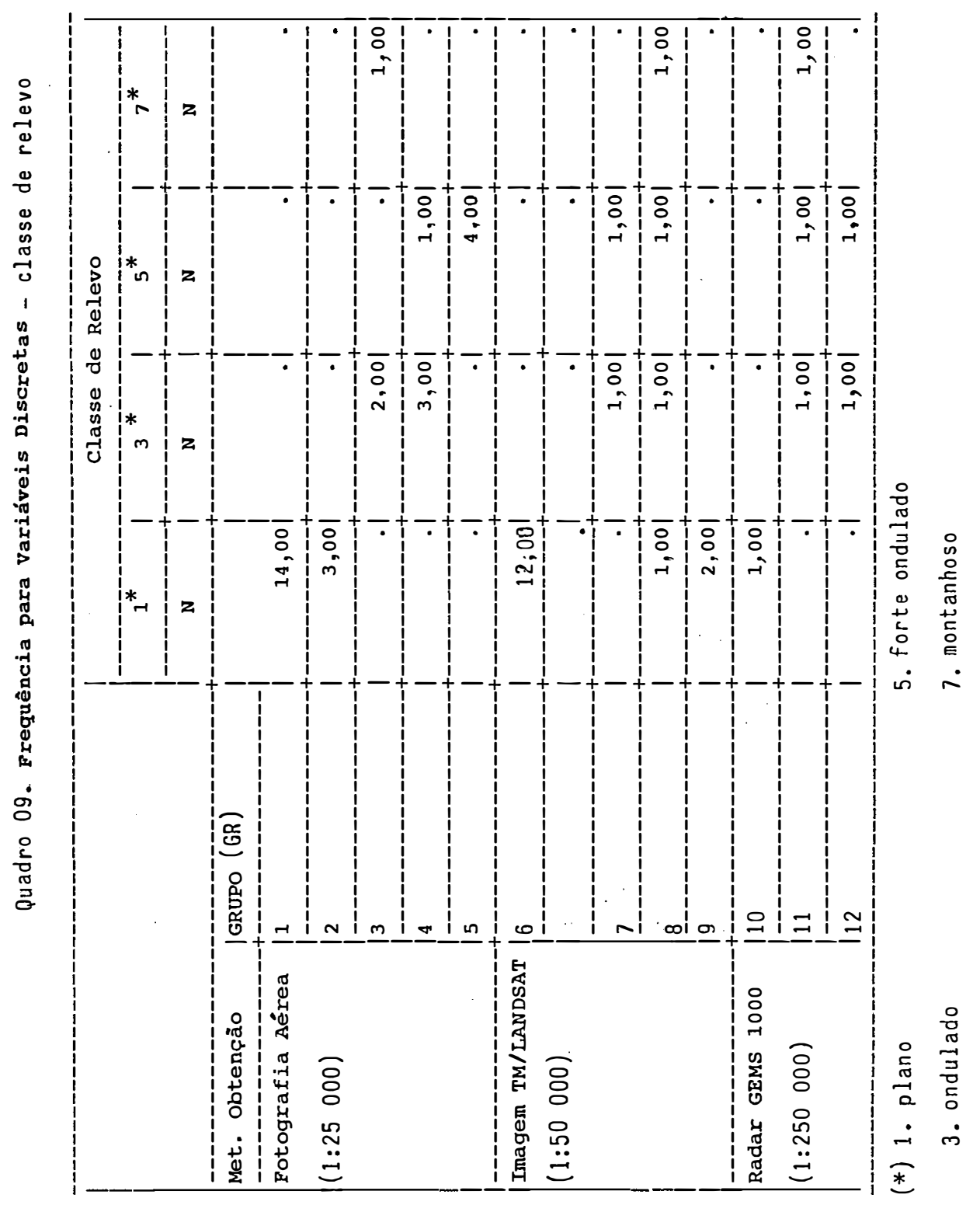




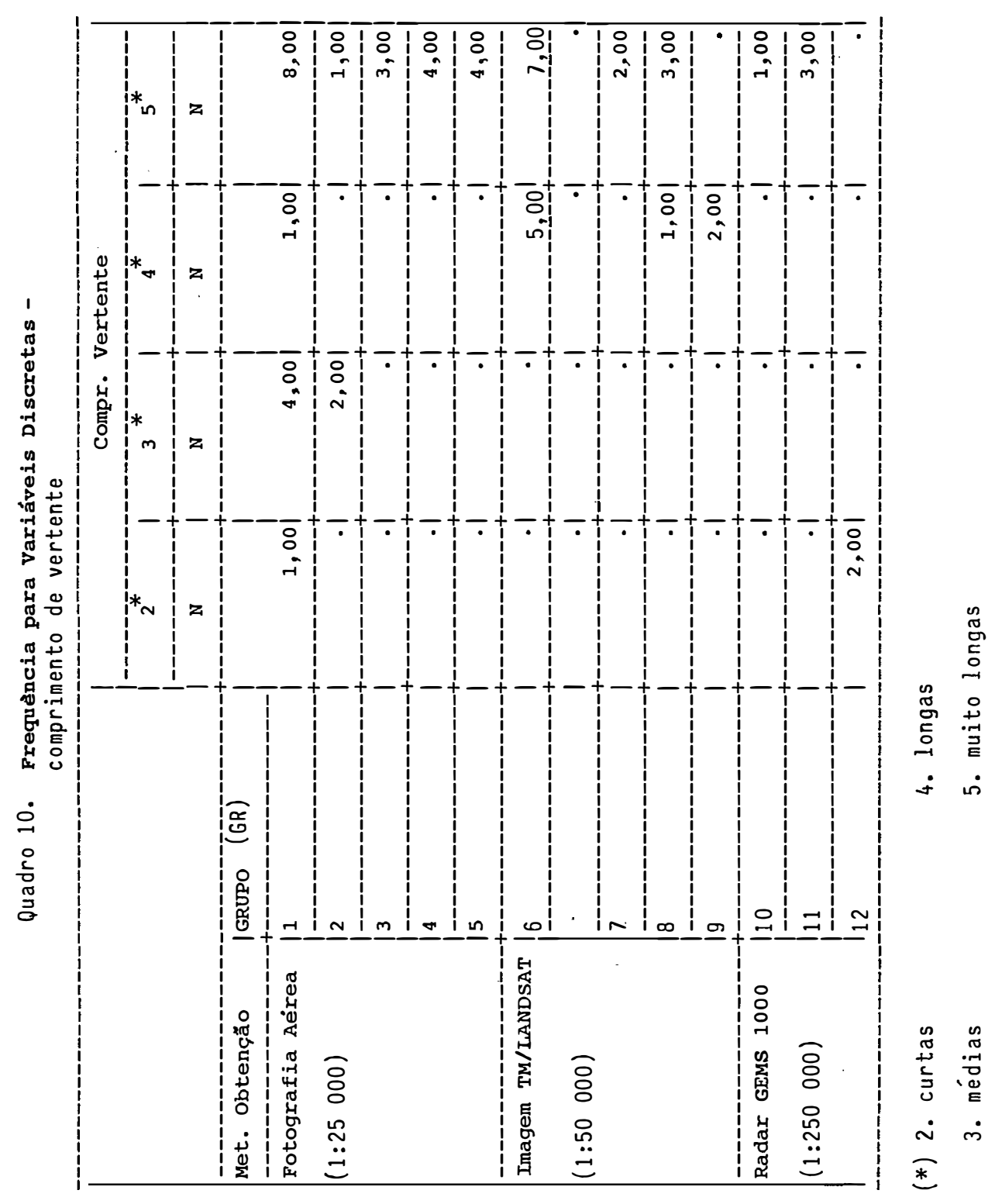




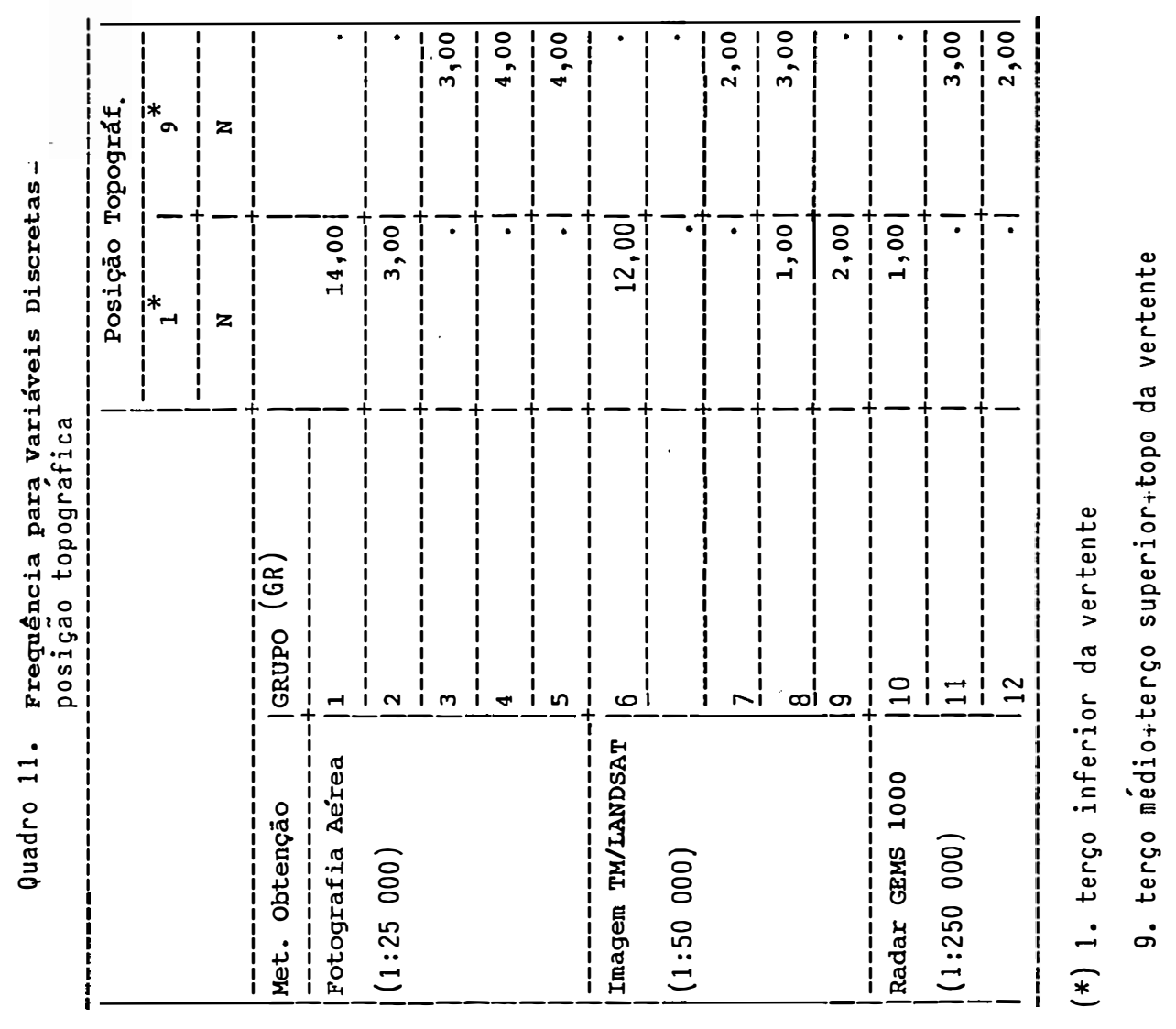

